\title{
Los estudios arqueológicos sobre al-Andalus en el noreste de la provincia de Guadalajara. Historiografía del siglo XVI al siglo XXI
}

\author{
Archaeological studies on al-Andalus in northeast province of Guadalajara: \\ historiography from 16th to 21th centuries
}

Guillermo García-Contreras Ruiz *

\begin{abstract}
RESUMEN
Se realiza una revisión crítica de la historiografía sobre los estudios arqueológicos dedicados al periodo de al-Andalus en el noreste de la actual provincia de Guadalajara. El trabajo se ha dividido en cinco periodos: del siglo XVI al siglo XVIII, del siglo XIX a la Guerra Civil, De los años treinta a la Transición, los últimos treinta años del siglo XX y finalmente un epílogo sobre los últimos quince años. Se examinan los principales temas que han sido discutidos, cómo unas obras han influido en las posteriores, el porqué de ciertos silencios y ausencias y, en general, la visión que se ha tenido sobre los restos arqueológicos de época andalusí en los últimos cinco siglos. Finalmente se plantea cuál es el estado actual de la arqueología sobre al-Andalus en este sector de la Península Ibérica.
\end{abstract}

Palabras clave: Al-Andalus, Guadalajara, Historiografía, Arqueología Medieval

\section{La historia interesada o el interés de la historia}

Cualquiera que visite el noreste de Guadalajara, no sólo las dos ciudades principales que son Atienza o Sigüenza, sino también los pueblos y aldeas de la zona (Alcolea del Pinar, Anguita, Carabias, Hiendelaencina, Imón, Jadraque, Riba de Santiuste o Sienes por citar sólo los de más renombre) se llevará la impresión de una tierra con una fuerte impronta medieval, por la existencia de castillos, torreones o iglesias románicas, pero también por sus

\begin{abstract}
A critical review of the historiography on the alAndalus archaeological studies in the northeast of the current province of Guadalajara is presented. The work has been divided into five periods: from the 16 th c. to 18 th c.; from the 19th century to the Civil War; from the Thirties to the Transition; the last thirty years of the 20th c.; and finally, an epilogue over the last fifteen years. The main issues that have been discussed are considered, it is discusses how some works have influenced subsequent, why certain silences and absences is explained and, in general, the view that has been taken on the archaeological remains of the Andalusian period shown in the last five centuries is shown. Finally, the state of the art of al-Andalus archeology in this sector of the Iberian Peninsula is approached.
\end{abstract}

Keywords: Al-Andalus, Guadalajara, Historiography, Medieval Archaeology

fiestas, sus trajes y tradiciones populares, y por sus cuentos y leyendas que refieren siempre a este periodo (MONTERO, 2005). Y sin embargo, todo este «medievalismo popular», esa abundancia de información, contrasta con la escasez de conocimiento histórico por la falta de investigaciones históricas y arqueológicas (CUADRADO, 2002: 99) y muy especialmente en lo que se refiere al periodo andalusí. Unas deficiencias aún mayores si se compara con las regiones limítrofes como la provincia de Soria, la vecina región de Molina de Aragón, o la comarca de la Alcarria. Es más, es una visión

\footnotetext{
* Contratado postdoctoral en la University of Reading (Reino Unido) gracias a una beca de perfeccionamiento de doctores del Plan Propio de la Universidad de Granada.
} 
de la Edad Media sesgada e incompleta, porque sus referentes no se atienen a la totalidad del periodo cronológico que abarcan los siglos $V$ al XV, sino a una determinada idea cultural, el feudalismo y el cristianismo, y a un momento concreto, el de la conquista del territorio y su incorporación al reino de Castilla, llegando como mucho hasta el periodo de esplendor de la provincia bajo los Mendoza. El porqué se construye esta narrativa histórica excluyente tiene mucho que ver con motivos ideológicos y políticos que afectan a la totalidad de la historia y la arqueología de al-Andalus (DÍAZ ANDREU, 1996; GARCÍA SANJUAN, 2011 y 2013), y no cabe duda de que están estrechamente relacionados con las estructuras académicas que sustentan la propia investigación y fijan sus intereses en uno u otro sentido.

La zona a la que vamos a acotar este trabajo corresponde al extremo noreste de la actual provincia de Guadalajara, un territorio situado en el sector oriental del centro peninsular, caracterizado a nivel geográfico por ser la confluencia entre dos sistemas montañosos (el Sistema Central y el Sistema Ibérico) lo que ha dado lugar a una orografía montañosa salpicada de valles por los que discurren distintos ríos, siendo el más importante de todos ellos el Henares. En lo que respecta al periodo andalusí, estuvo integrada en el espacio fronterizo denominado Marca Media, quedando bajo la órbita primero de la ciudad de Guadalajara y después de la de Medinaceli (en el sur de Soria), hasta que entre finales del siglo XI y principios del siglo XII fue conquistada por los castellanos. Los estudios arqueológicos sobre los siglos VIII al XII son relativamente escasos si bien están dando un salto cuantitativo -y valoraremos si lo es también cualitativo- en los últimos quince años. Por ello pensamos que es importante realizar un estudio historiográfico y bibliográfico sobre la zona analizada con el objetivo de observar qué se ha investigado hasta ahora, cuál es el panorama que ha presentado la literatura histórica, cuáles son las carencias y cuáles los hitos desde los que podemos partir. Y sobre todo, tratar de entender porqué hemos llegado al siglo XXI con esa falta de conocimientos sobre la arqueología de al-Andalus, y destacar así la importancia de los recientes trabajos que se están llevando a cabo.

Además de analizar detenidamente la historiografía de la comarca en lo que a la arqueología se refiere, pretendemos fijar las coordenadas generales por las que ha discurrido la visión histórica que sobre el periodo medieval y, especialmente, sobre el periodo andalusí, se ha tenido desde el inicio de la Edad Moderna hasta nuestros días.

No resulta fácil realizar un análisis de la producción historiográfica sobre al-Andalus individualizado para el sector noreste del Sistema Central, también denominado comarca del Alto Henares, ya que, salvo escasas y meritorias excepciones, esta región ha recibido poca atención específica con anterioridad al año 2010 (GARCÍA-SOTO, 2005; DAZA, 2007). En parte se debe a que no hay una clara definición territorial unitaria de esta zona hasta el momento posterior a la conquista feudal, cuando se formó el señorío episcopal de Sigüenza (BLÁZQUEZ, 1985). Por ello, cualquier estudio, incluido esta revisión historiográfica, se ve obligado a usar conceptos territoriales más amplios, aunque en la medida de lo posible, estrictamente históricos o más genéricamente geográficos. Sin ánimo de ser exhaustivos, algunos de los que se han usado hasta ahora en publicaciones antiguas o recientes proponen el uso de términos como pueden ser los de «el norte de la Alcarria» (GARCÍA LÓPEZ, 1894); o parte del valle del Henares (PAVÓN, 1984; BERMEJO y MUÑOZ, 1996, 1999; DAZA, 2007a; GARCÍA-CONTRERAS 2012a, 2013a); la «Celtiberia» o su derivado árabe de «Šantabariyya» (OLMO, 2011); el territorio de «Segontia», de Sigüenza o de la diócesis de Sigüenza (GARCÍA-SOTO, 2005; OLEA, 2009); la zona oriental de la Marca Media (Al-Tagr al-Awsat) (MARTÍNEZ y SERRANO-PIEDECASAS 1998; ZOZAYA, 2007; ALEJANDRE, 2014); también denominada en ocasiones como frontera Media de al-Andalus (ZOZAYA, 1991); la frontera de los «Banū Sālim» (GRANJA, 1967: 471, 492, y 526); la parte nororiental de la taifa de Toledo (BOLOIX, 2001); uno de los sectores de la Extremadura Castellana (SERRANOPIEDECASAS, 2007); el «partido judicial de 


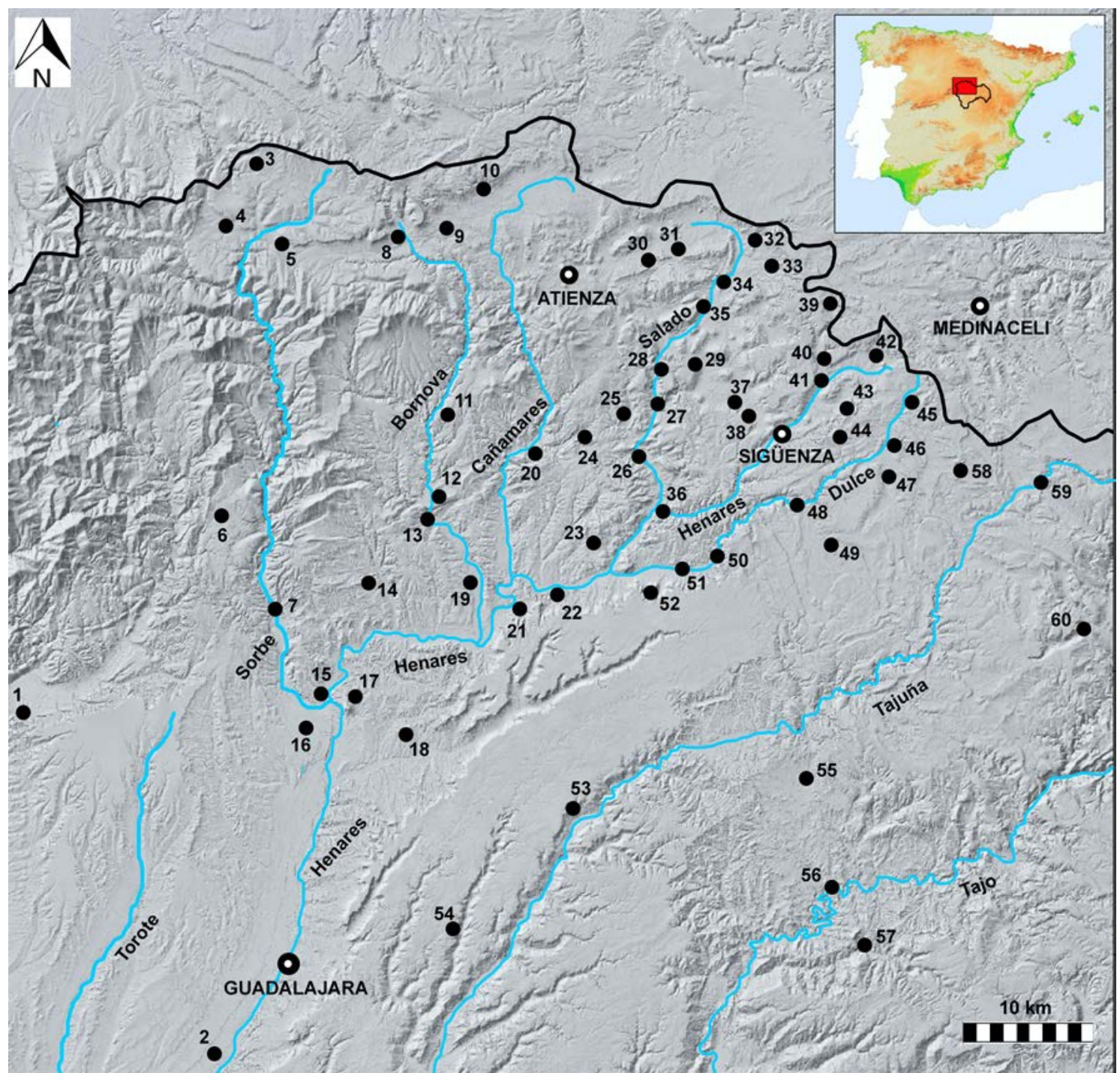

Fig. 1. Mapa indicando la localización de la zona estudiada, la ubicación de las principales localidades (Guadalajara, Atienza, Sigüenza y Medinaceli) y los pueblos o yacimientos mencionados en el texto: 1) Uceda, 2) Azuqueca, 3) Villacadima, 4) Cantalojas, 5) Galve de Sorbe, 6) Tamajón, 7) Beleña, 8) Albendiego, 9) Ujados, 10) Miedes, 11) Hiendelaencina, 12) Alcorlo, 13) San Andrés de Congosto, 14) Cogolludo, 15) Peñahora, 16) Humanes, 17) Alarilla, 18) Hita, 19) Membrillera, 20) Palmaces, 21) Jadraque, 22) Bujalaro, 23) Cendejas de la Torre, 24) Angón, 25) Santiuste, 26) Huérmeces, 27) Atance, 28) Santamera, 29) La Olmeda de Jadraque, 30) Alcolea de las Peñas, 31) Tordelrábano, 32) Valdelcubo, 33) Sienes, 34) Riba de Santiuste, 35) Imón, 36) Baides, 37) Carabias, 38) Palazuelos, 39) Olmedillas, 40) Alboreca, 41) Alcuneza,

42) Horna, 43) Guijosa, 44) Barbatona, 45) Bujarrabal, 46) Estriégana, 47) Sauca, 48) Pelegrina, 49) Torresaviñán, 50) Aragosa, 51) Mandayona, 52) Castejón, 53) Brihuega, 54) Atanzón, 55) Cifuentes, 56) Trillo, 57) Viana de Mondéjar, 58) Alcolea del Pinar, 59) Anguita, 60) Riba de Saélices

Sigüenza» (MORÉRE, 1983), o con un carácter más amplio y más reciente, el norte de la provincia de Guadalajara (HERRERA, 1985; VALIENTE, 1997; OLMO, 2002; GARCÍA-SOTO y FERRERO, 2008; GARCÍA-CONTRERAS, 2012b, 2015 y 2016a); o simplemente como la Sierra Norte aludiendo a la caracterización geográ- fica interna de la provincia (GARCÍA-SOTO, FERRERO y GUILLÉN, 2004; DAZA, 2005-2006; 2007b). Esta larga nómina de nombres distintos para referirse a la zona de estudio, incluso por parte de los mismos autores, muestra, por un lado la indefinición territorial del espacio, especialmente en época altomedieval, y por 
otro su vinculación a un territorio más amplio. Es decir, no hay una demarcación política ni administrativa clara que permita una definición nominal única y concreta.

Para este estudio han sido de gran utilidad las recopilaciones bibliográficas para la provincia de Guadalajara, especialmente las más antiguas. Se trata de una actividad que fue especialmente notable en tres periodos: finales del siglo XIX, en los años setenta y entre mediados de los ochenta y principios de los noventa (RADA, 1894; GARCÍA, 1899; SÁNCHEZ, 1967, 1969, 1970, 1977, 1979; BALLESTEROS, 1991; GARCÍA, 2004). Posteriormente, ya encontramos trabajos historiográficos específicamente dedicados a la arqueología del periodo medieval (ZOZAYA, 1991; CUADRADO, 2002; OLMO, 2002; SANZ, 2010, IZQUIERDO, 2011 y algunas breves notas en BUENO, 2011 y en ALEJANDRE, 2014: 19-31).

La estructuración del estudio sigue unos criterios preferentemente cronológicos, realizando varios grupos: del siglo XVI al XVIII, del siglo XIX a inicios de la Guerra Civil; de la Guerra Civil a los años sesenta; los años setenta y ochenta hasta mediados de los noventa; y por último desde mediados de los años noventa hasta la primera década del siglo XXI, aunque esta última es una etapa demasiado reciente como para poder examinarla con objetividad. Cada uno de esos grupos tiene una personalidad historiográfica propia, como intentaremos ir justificando en cada apartado. Ese conjunto de características que otorgamos a cada período, suma de los que hemos considerado principales rasgos de las distintas obras, nos permitirá huir del análisis pormenorizado de todas y cada una de las obras citadas, deteniéndonos sólo en las que consideramos especialmente notables. Sobre todo, la gran cantidad de títulos publicados durante finales del pasado siglo XX y principios del presente siglo XXI ha imposibilitado, si no se quería alargar en exceso el presente estudio, la realización de comentarios críticos de todos ellos, por lo que se ha optado por agrupar en grandes bloques las obras que guardan ciertas características comunes entre sí, o, sobre todo, las obras de un mismo autor, ya que guardan una cierta coherencia interna. En definitiva, pretendemos encontrar líneas argumentales y elementos de debate, que nos permitan ser conscientes del trabajo que se ha hecho, lo que se está haciendo y de lo que aún está por hacer.

\section{Historiografía sobre la Alta Edad Media en los siglos XVI al XVIII}

Se ha afirmado que la historiografía de carácter local a partir del siglo XV tuvo una escasa importancia, tanto por el número como por la calidad de las obras publicadas, o incluso, quedando muchas obras como manuscritos no publicados, perdidos en la actualidad o poco conocidos (BALLESTEROS, 1991: p. 30 y nota al pie 6). En lo que se refiere al periodo andalusí, se va a producir un fenómeno de ocultación en las crónicas de los hechos históricos correspondientes a los siglos plenomedievales así como una despreocupación por los restos materiales (CUADRADO, 2002: p. 100) muy en consonancia con el no reconocimiento de la islamización que comenzaba a gestarse (GARCÍA SAN JUÁN, 2012). Un proceso que se retroalimenta con la propia concepción del mundo medieval como época bárbara y oscura, contrapuesta a la grandeza de lo romano y al resurgir del Renacimiento (MITRE, 2003: pp. 78-88). Estas mismas ideas, y lo reciente del periodo, hará que no se tomen en consideración como arquitecturas o bienes artísticos dignos de ser reconocidos los restos arqueológicos de los siglos altomedievales por parte de los humanistas y los ilustrados, mucho más atentos a los restos del periodo romano (SANZ, 2010: pp. 20-25).

No obstante, en este periodo, llama la atención el incipiente interés de algunas personalidades por recuperar la memoria de algunos restos antiguos como por ejemplo Ambrosio de Morales (1513-1591). Entre otras actividades, contrastó fuentes literarias y arqueológicas; trató de continuar la publicación de la Crónica de España (libros VI al XVIII) que había iniciado Florián de Ocampo; y recomendó a Felipe II realizar el interrogato- 
rio contenido en las Relaciones Topográficas donde se incluyeron preguntas sobre restos antiguos, incluidos los de tiempo de moros (SANZ, 2010: p. 20).

Las Relaciones Topográficas pueden ser consideradas como un interrogatorio con fines fiscales redactado durante el reinado de Felipe Il según instrucciones recibidas desde la Corte, y que sirvieron para recopilar información de un gran número de pueblos de Castilla, incluidos los de la provincia de Guadalajara (GARCÍA y PÉREZ, 1903-1915). Se hizo un primer interrogatorio en 1575, al que no respondieron todos los pueblos, por lo que se encomendó un segundo en 1578. En conjunto, son una serie de preguntas que versan sobre geografía, historia, economía, sociedad, religión, demografía, cultura, costumbres, instituciones etc., de enorme valor para los historiadores. De las aproximadamente cincuenta preguntas o capítulos que componen estas «Relaciones», más de veinte interrogan directa o indirectamente sobre asuntos históricos, y algunas específicamente sobre restos materiales, como edificios, columnas, sepulcros... que se vinculaban a los romanos o a los musulmanes, en cualquier caso, al pasado no cristiano. Destaca el tercer capítulo que cuestiona sobre «si el dicho pueblo es antiguo o nuevo y desde que tiempo acá está fundado, y quien el fundador, y quando se ganó a los Moros, o lo que dello se supiere». Otros apartados cuestionaban sobre desde cuándo eran núcleos considerados ciudades o villas, o sobre el porqué del escudo de armas que tuvieran. Tras seguir abordando la situación general que los pueblos de la época sobre los ámbitos administrativos, geográficos, económicos y religiosos, vuelve a interesarse por la historia de las poblaciones: las cuestiones de la 27 a la 31, y las 38, 39, 42 y 43 preguntan cómo son los asentamientos, cercas o murallas, castillos, torres, casas o edificios principales, monasterios, iglesias y otras construcciones religiosas. También se consulta por los restos de epitafios, letreros, «antiguallas» (pregunta 31) y por los privilegios y franquezas que tuvieran (número 37 ).

Para comprender en su totalidad estos cuestionarios, hay que atender no sólo a los personajes de la Corte que los elaboraron (ORTIZ, 1999: p. 92), sino también a las personas que los contestaron en cada pueblo, para estimar su valor y la calidad de la información que nos proporcionan. En las instrucciones enviadas a los pueblos para explicarles cómo cumplimentar las preguntas o capítulos del interrogatorio, se ordenaba que «nombraran dos personas o más, inteligentes y curiosas de los pueblos donde residen, que hagan la relación dellos lo más cumplida y cierta que se pueda». Tomando la totalidad del interrogatorio, se observa que en la provincia de Guadalajara en la mayoría de los casos (130 de 148), los autores de las respuestas eran simples vecinos, salvo que en ocasiones se refiere a ellos como «las personas más discretas y más entendidas que había en la villa» O calificativos similares (BALLESTEROS, 1991: pp. 31-33).

En los pueblos de Guadalajara y, más concretamente para los de la Alcarria - que han sido mejor estudiados-el conocimiento del pasado histórico por parte de los aldeanos de finales del siglo XVI no era muy profundo (BALLESTEROS, 1991: pp. 34-35). En la mayoría de los casos, sobre la fundación y origen del pueblo solo se dice que es "antiquisimo», que existe «desde que se acuerdan», o bien, como se indica en el cuestionario sobre Santamera, una de las localidades del noreste de Guadalajara, "dixeron quel dho lugar de Santamera siempre ásido, y es tenido pr. lugar antiguo é no nuebo, é que no saben quien le fundó, ni quando se ganó delo Moros» (GARCÍA y PÉREZ, 1903-1915). Y las mismas generalidades imprecisas se pueden rastrear cuando se habla, por ejemplo, de los despoblados vecinos, con poquísimas excepciones como la de Fuencaliente (en Ciudad Real) en la que «parece haber muchos castillejos antiguos y otros edificios, que por lo que de ellos se colije fueron hechos y habitados en tiempos de moros» (SANZ, 2010: p. 31 y nota al pie 3).

Respecto a la forma en que tienen de referirse al periodo andalusí, a los musulmanes y a su dominación, lo primero a destacar es que el hecho de hacer referencia a los «moros» es sinónimo de antigüedad y con ello de 
importancia, como ocurre también en Calamocha (Teruel) (ORTEGA, 2000). Son varios los pueblos que tras indicar que su origen era muy antiguo, añaden que «fue de moros» para probar dicho dato (BALLESTEROS, 1991: pp. 35-36). En algunos, incluso, se hace referencia a restos de edificaciones cuya construcción se les atribuye. En la zona estudiada, tenemos sólo un caso, aunque nos parece de especial relevancia. Se trata del pueblo de Santamera, antes mencionado, en cuyo cuestionario, a la pregunta sobre los «edificios antiguos, epitafios y letreros, y antiguallas de que hubiese noticia», se responde:

\section{Alos treinta y seis capitulos dixeron: que en el termino del dho lugar en un alto ay unos edificios de moros mui fragosos é peligrosos paralos q. de ellos se quissiesen defender, é sellama el Castillo Elamotilla. (GARCÍA y PÉREZ, 1903-1915)}

Incluso, más adelante, en la pregunta referente a las iglesias y ermitas que hubiera en la localidad, se responde que:

\section{Alos cinquenta é un capitulos dixeron que en el dho pueblo de Santamera ay una hermita que se llama Santa Melen- ciana que esantigua, y dicen que era hija de un Rey Moro, la qual daba álos pobres de comer q. nolo viese nadie. (GARCÍA y PÉREZ, 1903-1915)}

Algo parecido podemos encontrar en las respuestas de la aldea de Santiuste en el interrogatorio de 1578:

\section{A los treinta y un capitulos dixeron que en el dicho pueblo de Santiuste ay ciertos rastros de edificios antiguos, especialmen- te la Yglesia que dicen era mezquita de moros. (GARCÍA y PÉREZ, 1903-1915)}

Esta misma idea se repite en otras localidades de la actual provincia de Guadalajara, como en Illana, donde se señala que había una casa con un arco que la individualizaba del entorno, de la cual «dicen que fue mezquita», y algo similar ocurre en Hueva, Almoguera, El Cubillo, Balconete, Beleña, Uceda, Atanzón,
Azuqueca o la propia ciudad de Guadalajara (BALLESTEROS, 1991: p. 36 y nota al pie 22).

Otra fuente de información, aunque más indirecta, es la toponimia contenida en este documento, que permite por ejemplo aproximarse a las construcciones defensivas (RANZ y LÓPEZ, 1997). Lamentablemente, estas Relaciones Topográficas no se han conservado para todos los pueblos, y no se incluyen la mayoría de los que hoy forman los partidos judiciales de Sigüenza y Molina de Aragón. Debido a ello, en lugares como Atienza, debemos recurrir a otro tipo de documentación que ni es tan exhaustiva, ni proporciona esa valiosa información histórica que dan las respuestas al cuestionario (GARCÍA LÓPEZ, 1992: pp. 179183 y 189-191).

Para el siglo XVII, el panorama historiográfico no cambió mucho y la atención sobre el medievo sigue siendo a partir de la conquista castellana y posterior cristianización. Si acaso, se presta atención a la posible existencia de cristianos bajo el dominio de los árabes y su consiguiente «liberación» (FERNÁNDEZ, 1985). Los que se interesaron por la historia en aquel siglo, como Francisco de Torres, Salazar de Mendoza, el padre Mariana o fray Hernando de Pecha, parecen más «juglares compositores de gestas que historiadores en el sentido científico de la palabra» (FERNÁNDEZ, 1985: p. 28). Todos prestaron atención sólo hacia los grandes núcleos de población, fundamentalmente la propia ciudad de Guadalajara, y en mucha menor medida Sigüenza, como sede episcopal. Desde entonces, y hasta la segunda mitad del siglo XX, la historia sobre esta región usó siempre como periodización la sucesión de obispos en la diócesis. La historia eclesiástica, y las relaciones del resto de actividades - productivas, comerciales, artísticas - con la Iglesia y sus representantes, se convirtió en el principal objeto de estudio histórico. Es, nuevamente, un tipo de historia que, o bien se centra en los orígenes del cristianismo y los primeros obispos de la diócesis seguntina, o bien empieza en el siglo XII con la reinstauración de la sede episcopal, pero que en ningún caso fija su atención en al-Andalus. 
A finales del siglo XVIII, José Andrés Córnide Saavedra redactó unas memorias de sus viajes por Madrid y Guadalajara con el objetivo de localizar vestigios romanos y definir el área de lo que en los textos se llamaba "Celtiberia» (VALLEJO, 1999) ${ }^{1}$. Estos viajes formaron parte de un programa más amplio, en el que recorrió toda la Península Ibérica y parte de Portugal, propio de los viajeros de la ilustración, en los que conjugaba el interés erudito con labores de documentación al servicio del Estado (ABASCAL y CEBRIÁN, 2009). En sus escritos, el interés que muestra por el periodo medieval y concretamente el andalusí, es prácticamente nulo. Solo algunos datos pueden ser útiles. Por ejemplo, en el caso de los dos cerros conocidos como las Tetas de Viana, entre los municipios de Trillo y Viana de Mondéjar da a conocer por información oral la existencia de "vestigios de población o castillo morisco» (VALLEJO, 1999: p. 47), en el lugar en el que más tarde se ha documentado un yacimiento arqueológico pluriestratigráfico, que abarca desde el paleolítico hasta la Guerra Civil, incluyendo un asentamiento islámico (VALIENTE, 1997: pp. 97-100; MARTíNEZ y MALLA, 1990).

Algo parecido ocurre con Sigüenza, de la que quiso

... averiguar a dónde estuvo la antigua población que le dio nombre, en el supuesto que la actual no tiene señales de ser pueblo romano o anterior al dominio de estos, ni los trozos de muralla que conserva son de aquel tiempo y si muy posteriores. Acordéme que Gaspar Barreiros, en su viaje a Italia, dice que la antigua Seguntia estaba en un cerro llamado Villavieja, media legua más adelante caminando a Aragón. Pregunté a algunos por el tal Villavieja pero no supieron darme razón y sólo mostraron otro cerro como un cuarto de legua en el mismo camino y me dijeron se llamaba del Otero; determinéme a pasar a él pero no hallé el menor rastro de antigüe- dad, ni aun espacio para una población como debía ser Segontia. (VALLEJO, 1999: p. 66; ABASCAL y CEBRÍAN, 2009: p. 244)

Posteriores estudios han localizado y definido el lugar de Villavieja como un yacimiento multifásico que incluye, al menos, fase de la Edad del Hierro y del periodo andalusí (GARCÍA-CONTRERAS, 2014).

En definitiva, vemos como la producción histórica, sobre todo a partir del siglo XVII, fue en cierta medida «copiosa» para la región alcarreña (BALLESTEROS, 1991: p. 43) pero no muy productiva en lo que a los restos arqueológicos andalusíes se refiere. Lo más numeroso fueron las obras sobre centros religiosos, como el seguntino, ya que era sobre su fundación, o restauración, lo que se considerada como el principio de la historia digna de ser contada.

\section{Historiadores y arqueólogos del siglo XIX a la Guerra Civil}

1 Los escritos en los que Córnide alude a la provincia de Guadalajara son variados y de distinta naturaleza. Los que más nos interesan son los cuadernos reunidos bajo los títulos «Viaje a la Alcarria Alta» y «Viaje executado en el mes de septiembre de 95 desde Madrid a Sigüenza por la Alcarria para determinar la posición geográfica de la Celtiberia», ambos fruto de los viajes que realizó en los años 1794 y 1795 respectivamente. 
Con estas palabras referidas a Sigüenza, que datan de 1806, se inicia un nuevo periodo en la historiografía. Desde finales del siglo XVIII y especialmente al principio del siglo XIX, los restos medievales comenzaron a ser valorados, pero siempre en un marco de preocupación de los historiadores y cronistas por remontar cada vez más atrás en el tiempo el origen de cualquier localidad y, preferentemente, al momento de la dominación romana o, al menos, del cristianismo más primitivo. Así, aparecen en ocasiones citados todos los hallazgos posibles (reales, transmitidos por tradición o incluso ficticios) que pudieran servir para demostrar el origen remoto de esas localidades. Y sobre todo de las ciudades que fueron consolidándose como capitales de provincia. En este proceso, edificaciones medievales como murallas o construcciones civiles eran mencionadas en algunas ocasiones como romanas (CUADRADO, 2002a: 100). En el contexto general, el periodo andalusí era considerado un periodo extraño, de invasión y ocupación, «naturalizado» y devuelto a la «normalidad» con la conquista cristiana y la unificación «nacional» de España (GARCÍA SANJUÁN, 2011 y 2012: pp. 68-82).

A partir de mediados del siglo XIX, comienzan a aparecer obras referentes al marco territorial de Guadalajara en las que se valora la etapa medieval y en las que comienza a usarse la arqueología como instrumento para su interpretación. A este avance contribuyó, en gran medida, la creación de las Comisiones Provinciales de Monumentos Históricos y Artísticos, con la intención de recoger y preservar todos los bienes procedentes de la Desamortización. La de Guadalajara, comenzó a funcionar en 1835 , con altibajos en su funcionamiento hasta su desaparición a mediados del siglo XX (SERRANO y CABALLERO, 1994; LÓPEZ y GARCÍA-RISCO, 1996, LÓPEZ, 1997). A finales del siglo XX comenzó a rescatarse gran parte de la documentación que generó esta institución (GÓMEZ-PANTOJA y LÓPEZ, 1996), así como otras similares como la Real Academia de la Historia (MAIER, 1999). La Comisión de Guadalajara fue de las más activas de España, preparando y enviando entre 1844 y 1845, un cuestionario de 72 preguntas a todos los pueblos de la provincia. De ellos se conservan actualmente en el Archivo Histórico Provincial de Guadalajara 352 cuestionarios, 14 de ellos en blanco. Desgraciadamente no se encuentran los correspondientes a Guadalajara capital ni a Sigüenza ni Atienza, pero sí a otras muchas localidades ${ }^{2}$. Este cuestionario, compuesto de dos folios por las dos caras, dedicaba 16 preguntas a monumentos romanos, 36 a monumentos de la Edad Media (casi todos sobre iglesias), 10 preguntas sobre monumentos árabes y 9 preguntas sobre monumentos del Renacimiento. Además, en aquellas localidades en las que sí se documentaron restos arqueológicos de interés, a los dos folios del cuestionario se añadía una página manuscrita en la que se describía algo más extensamente lo que se contestaba en el cuestionario. Por poner un solo ejemplo, en el caso de Alcolea de las Peñas se señala que:

En el centro del Pueblo y sitio que llaman la (...) haciendo escabaciones se han hallado bastantes huesos humanos. En las piedras areniscas que forman el suelo de la población se encuentran algunos huecos en forma de Cisternas. También se encuentran otros en figura de Sepulcros. ${ }^{3}$

Estos huecos en la roca son aún hoy visibles, y han sido recientemente analizados como posibles evidencias de producción salina, si bien su cronología es algo incierta (MORĖRE, JIMÉNEZ y GARCÍA-CONTRERAS, 2013).

Las preguntas referentes a la Edad Media están destinadas en su mayoría a interrogar sobre los edificios religiosos, y sólo dos de ellas, la 33 y la 34, preguntan por restos como

\footnotetext{
2 Respuestas de 1844, en Archivo Histórico Provincial de Guadalajara (AHPG), Comisión de Monumentos (CM), Caja 1. El cuestionario está organizado por partidos judiciales, de los cuales hemos consultado los de Atienza (52 localidades) y Sigüenza (48 localidades). Están recogidos también los de Brihuega, Cifuentes, Cogolludo, Molina, Pastrana, Sacedón y Guadalajara.

3 «Alcolea de las Peñas», Respuestas de 1844, AHPG, CM-1.
} 
castillos u otras fábricas de antigüedad ${ }^{4}$. Del espacio dedicado a indagar sobre el periodo árabe en el interrogatorio acaso lo más interesante sean las propias preguntas en sí mismas, ya que revelan en gran medida qué idea se tenía de lo que debió ser el periodo andalusí. Eran unas preocupaciones fundamentalmente ligadas a cuestiones artísticas, pero entre ellas destaca el interés por el agua en el interior de las construcciones, o por la posibilidad de que hubiera torres y torreones, aspectos sumamente interesantes en la arqueología andalusí hoy en día, y que ya en el siglo XIX parecían definir lo que se entendía como característico del periodo árabe ${ }^{5}$.

No son muchas las respuestas positivas que se dieron, quizás como reflejo del desconocimiento o el desinterés de la sociedad de la época por estos posibles restos. Salvo en lo referido a las iglesias y ermitas, los alcaldes y curas párrocos, a quienes se obligaba a firmar al final de cada interrogatorio, o quienes respondieron a los cuestionarios, no mostraron en general gran interés por cumplimentar estos cuestionarios de manera detallada, salvo algunas excepciones que conviene señalar. No sólo en la zona objeto de nuestro interés, sino también en otras partes del norte de Guadalajara como en Cantalojas, por ejemplo, donde se alude a la existencia del castillo de Diempures ${ }^{6}$, que además conectan visualmente a través de otra posible torre atalaya tanto con Atienza como con Gormaz (GARCÍA-CONTRERAS, 2015); o en Ujados donde «... se hallan en barias casas unos oyos redondos en piedra arenisca echos apico y no se sabe su profundidad dicen son echos por los moros... ${ }^{7}$ similares a los que veíamos anteriormente para Alcolea de las Peñas y en una localidad en la que se han identificado restos arqueológicos altomedievales (DAZA y CATALÁN, 2009). En los documentos de Tordelrábano y Valdelcubo se mencionan despoblados, los de Morenglos y Torrequebrada respectivamente, aunque no se dice explícitamente que sean de época andalusí, algo que recientemente ha sido propuesto (DAZA, 2005-2006; MALPICA y GARCÍA-CONTRERAS, 2010; GARCÍA-CONTRERAS, 2012c). Sí se especifica en el caso de Barbatona, por ejemplo, ya que en la nota que acompaña al cuestionario dice que «Existe una casa antigua, su fabrica de mamposteria muy fuerte y las bovedas de sillería, se cree haya sido algun fortin del tiempo de los Sarracenos» ${ }^{8}$. También sobre la localidad de Estriégana se dice que «Ay un torreón arruinado y no se sabe a que época pertenece si a la de los romanos o a los moros»?. Efectivamente, tanto en Barbatona como Estriégana, existen sendos torreones andalusíes como se ha analizado en fechas recientes (MORĖRE, 1983; GARCÍA-SOTO y FERRERO, 2008; GARCÍA-CONTRERAS, 2013a y 2016a).

Llama la atención que habiéndose realizado estas referencias a las torres de Barbatona y Estriégana, en el caso de Bujarrabal nada se nos diga de la que allí existe y es visible hoy en día (GARCÍA-CONTRERAS, 2013a), quizás porque entonces estaba embutida en alguna construcción. También hay otros silencios

4 En concreto se pregunta: «33. Hay en el término de ese pueblo algun antiguo castillo? en que estado se halla? Está habitado? Tiene alguna tradicción interesante?» y «34. Hay en ese pueblo alguna otra casa, cuya fábrica se refiera á una antiguedad respetable? Qué adornos particulares tiene? se halla en mitad de las plazas algun poste ó monumento que tenga carácter de antigüedad? A qué época parece referirse?». Respuestas de 1844, AHPG, CM-1.

5 Las preguntas referidas al periodo árabe en concreto son: «1. Qué edificios árabes hay en ese pueblo? 2. Hay tradición de que hayan sido alcázares, mezquitas, ó servido de sinagogas? 3. De cuantos pisos se componen? Los arcos son de herradura, lisos ó dentellados? 4. Están los muros cubiertos de labores ó solo tienen algunas fajas? Los techos son dorados ó están pintados de colores? Son artesonados ó embovedados? 5. Hay fuentes en medio de las habitaciones? 6. Los balcones ó ventanas cuántas columnas tienen en el centro y á los lados? 7. Se encuentran algunas inscripciones antiguas entre los adornos? 8. Hay algunos torreones de este género de arquitectura? De cuántos cuerpos? Cuántas ventanas hay en ellos? Acaban en almenas ó son redondos? 9. Se encuentran lápidas, medallas y otros objetos árabes en las ruinas de algunas casas, ó en las inmediaciones de este pueblo? 10. Tienen las torres árabes alguna tradición histórica? A qué época se refiere?» Respuestas de 1844, AHPG, CM-1.

6 «Cantalojas», Respuestas de 1844, AHPG, CM-1.

7 «Hujados», Respuestas de 1844, AHPG, CM-1.

8 «Barbatona», Respuestas de 1844, AHPG, CM-1.

9 «Estriégana», Respuestas de 1844, AHPG, CM-1. 
notables, y así, ni en Santamera, ni en Alboreca, ni tampoco en Aragosa ni en Huérmeces se indica que hubiera habido restos arqueológicos de interés, o lo que es más llamativo aún, en Baides no se indica que hubiera un castillo, a pesar de ser localidades que conservan en muchos casos restos emergentes hoy en día (GARCÍA-CONTRERAS, 2013a). Hay que reseñar que en ningún caso se dan pruebas del porqué de la adscripción cronológica que se dan a algunos edificios, basados más en tradiciones orales que en pruebas que lo sustentaran. No quiere decir con ello que erraran en sus apreciaciones, ni es momento aquí para entrar en esta cuestión. Pero sí dejar constancia de casos como el de Pelegrina, en el que su castillo es considerado «....construido en tiempo de la dominación de los Moros» ${ }^{10}$.

En general vemos como la información que proporciona este cuestionario es escasa, al igual que el resto de la documentación decimonónica. Porque, salvo el interrogatorio de la Comisión de Monumentos, y algunas otras menciones a la existencia de vías romanas, o yacimientos, siempre de época antigua o visigoda, como los de Aguilar de Anguita, o algunos objetos de hueso tallado adscritos como prehistóricos, prácticamente no hemos encontrado ninguna referencia al periodo andalusí en ninguna obra, siendo tan escasas en general las referencias al medievo que casi se reducen a escribir sobre la escultura del Doncel en la catedral de Sigüenza. La Edad Media fue para el siglo XIX lo mismo que la Antigüedad para el Renacimiento, pero muy especialmente el mundo germánico pasa por ser lo prioritario en estas consideraciones, y en segundo lugar, el propio proceso de la expansión feudal o «Reconquista», ya que es el momento en el que se forjan los conceptos de patria y nación (MITRE, 2003: pp. 88-89).

Una importante obra a la que debemos hacer referencia es la Crónica de la provincia de Guadalajara de José María Escudero (ESCUDERO, 1869), la primera visión en conjunto de la actual provincia y que incluye, por lo tanto, la comarca nororiental que nos interesa. A una breve introducción geográfica, le siguen el estudio de los primeros pobladores (capítulo II), una historia eclesiástica de la provincia (capítulo III), una historia de Guadalajara capital (capítulo IV), las historias de las poblaciones más importantes en el momento de escribirse la obra y la de aquellas con un importante pasado histórico: Atienza, Hiendelaencina, Brihuega, Hita, Cifuentes, Trillo, Cogolludo, Molina y su Señorío, Pastrana, Zorita, la antigua Recópolis, La Isabera y por supuesto Sigüenza (capítulos V y VI), para terminar con los datos estadísticos: población, pósitos, instrucción pública, industria etc. que presentaba un conjunto de la provincia en la época de su publicación. Esta obra, si bien presentaba ya -tanto en su estructuración como en parte de su contenido- aspectos que la vinculan con los estudios plenamente científicos que aparecieron poco después, conserva limitaciones claras que la unen a la producción historiográfica del pasado. En sus páginas aún hubo cabida para algunas leyendas y fábulas recogidas de autores anteriores.

Sobre el periodo que nos interesa, este trabajo pasa de puntillas, ya que encadena la conquista romana con la «historia eclesiástica de la provincia» y especialmente de la vida pública de los obispos (ESCUDERO, 1869: pp. 17-31). Sólo al hablar de la ciudad de Guadalajara, dedica algunas páginas a explicar todo el proceso de conquista y control por parte de los musulmanes, exponiendo cuestiones referentes a la territorialidad y a la inclusión de la provincia de Guadalajara en las tierras fronterizas de al-Andalus (ESCUDERO, 1869: pp. 32-35). Esta obra sintetiza en gran medida, el perfil historiográfico e ideológico de la época, en el que la época andalusí simplemente no tiene cabida o sólo sirve de preámbulo a la posterior conquista por parte de los reyes castellanos, como ocurre en el caso de Atienza (ESCUDERO, 1869: p. 52). En cuanto a Sigüenza, tan solo refiere que «fué teatro durante

10 «Pelegrina», Respuestas de 1844, AHPG, CM-1. 
la dominación sarracena, de las sangrientas escenas á que dió lugar la enemistad del valí de Toledo Samail, con Aber-ben-Amrú....» sin citar ninguna fuente (ESCUDERO, 1869: p. 62). En ambos casos, Sigüena y Atienza, el origen de las villas se remonta a época prerromana, tratando su urbanismo en clave de continuidad desde época romana hasta el momento en el que escribe la obra, pero sin aportar realmente información sobre restos arqueológicos.

Para la mención y estudio de las antigüedades y restos materiales del pasado en el sector oriental del Sistema Central, hay que esperar a finales del siglo XIX, cuando una serie de académicos vinculados, por motivos, diversos, con la provincia, mantuvieron entre sí discusiones sobre la ubicación de los lugares citados en la documentación escrita, a partir de los análisis realizados sobre el terreno. Un avance cualitativo y en lo referido al periodo medieval, se lo debemos a Manuel Pérez-Villamil y sobre todo a Juan Catalina García López, los cuales introdujeron una visión crítica de la historia y utilizaron el método comparativo para la datación de los edificios y de sus elementos (ORTIZ, 1999: pp. 77-86; HERRERA, 1987: pp. 347-349). Ambos tuvieron en común el haber reconocido la importancia del periodo medieval en la provincia, y la recuperación de los restos de esta etapa para caracterizar la fisonomía de la población, dejando los dos clara la utilidad de la arqueología para estos fines (CUADRADO, 2002: p. 103). Especialmente se ha resaltado el papel de Juan Catalina García en el campo de la Historia y la Arqueología Medievales, ya que hizo aumentar considerablemente la bibliografía de la provincia con estudios parciales sobre monumentos y restos arqueológicos encontrados y excavados por él. Es necesario reconocer que «fue el auténtico iniciador de los estudios en el campo de lo medieval, tanto desde el punto documental como dese el arqueológico, en lo que a la provincia de Guadalajara se refiere» (CUADRADO, 2002: p. 105).

La colaboración entre ambos, Juan Catalina García y Manuel Pérez-Villamil se plasmó en la actualización de las Relaciones Topográficas que ya hemos citado anteriormente (GARCÍA y PÉREZ, 1903-1915), donde se matizan y completan las informaciones sobre las edificaciones y restos, así como otros aspectos referentes a la población o a cuestiones eclesiásticas, a los que se hacía referencia en las respuestas dadas por las poblaciones en los Aumentos a las encuestas, que los autores de los siglos anteriores no habían tenido en cuenta.

Es importante destacar la rigurosidad con la que ambos trabajaron. Aún siendo hijos de su tiempo en muchos otros aspectos. se atrevieron a contradecir algunas de las tradiciones heredadas sobre la historia de la región. Por ejemplo, Pérez-Villamil reflexionó sobre el hecho de que en Sigüenza no habían aparecido hasta el momento restos de construcciones verdaderamente árabes, salvo «un trozo de arco encerrado en un cuchitril de la casa número seis de la Travesaña Baja, sobre el cual corre una inscripción de carácter puramente decorativo» (PÉREZ, 1899: pp. 32-33).

De las obras de Juan Catalina García, quizás las más conocidas, por su alto valor historiográfico, sean su magna obra sobre los escritores de la provincia de Guadalajara y su bibliografía (GARCÍA, 1899) ${ }^{11}$ y su discurso de ingreso en la Real Academia de la Historia en 1894. En esta última esboza el panorama medieval de la provincia, con especial atención al periodo comprendido entre los siglos XI al XIII, describiendo los itinerarios seguidos tanto por cristianos como por árabes, basán-

\footnotetext{
11 Esta obra tiene dos partes bien diferenciadas. La primera está constituida por 280 artículos o apartados que corresponden a los estudios bio-bibliográficos de otros tantos escritores. Todo autor nacido en la provincia de Guadalajara hasta finales del siglo XVIII quedó registrado en esta magna obra en la que las biografías fueron completadas, en cada caso, con las noticias de sus escritos. Son 1233 las obras reseñadas en esta primera parte. En la segunda aparecen 711 reseñas más que atañen a libros o papeles biográficos diversos. En total son casi 2000 las obras estudiadas. Tras detenerse en la ficha técnica de la obra, su estructuración por capítulos o temática, consagra su estudio al contenido y naturaleza de la misma. Además de aportar una completa bibliografía de temas históricos alcarreños, sigue poniendo las bases de la historiografía científica de la provincia al refutar las diversas leyendas o tradiciones recogidas por los autores anteriores, señalando el motivo de su credulidad o las fuentes viciadas por ellos utilizadas.
} 
dose en fuentes documentales y arqueológicas, introduciendo por primera vez los datos materiales para el análisis crítico de la historia medieval de la provincia (GARCÍA, 1894). Como ya señaló Plácido Ballesteros, «Esta obra de síntesis es la base sólida y certera de la que han partido todos los estudios posteriores dignos de tenerse en cuenta que sobre la Alcarria medieval», pudiendo decir sin ningún tipo de ambages que «fue el verdadero padre de la historiografía científica alcarreña». Y aunque "no pudo evitar ser fruto de su tiempo», y reconociendo que «ciertos aspectos de ella - sobre todo lo políticos e institucionales-difícilmente pueden ser superados» no cabe duda que los aspectos sociales y económicos a veces no son tratados o lo son escasamente. (BALLESTEROS, 1991: pp. 58-60)

Entre las tareas más señaladas que acometió don Juan Catalina García, debemos destacar también la elaboración del Catálogo Monumental de la Provincia de Guadalajara, que comenzó a redactar a principios del siglo $X X$, y que no pudo terminar ya que murió antes de finalizarlo, pero que dejó bastante avanzado (GARCÍA, 1906-1911). Describe los hallazgos en 93 pueblos de esta provincia, y aunque la mayoría quedan fuera del sector de nuestro interés, algunas de sus consideraciones son de gran de interés para entender el contexto historiográfico de la época en lo que a al-Andalus se refiere. Por ejemplo, al hablar de San Andrés del Congosto, indica que su ubicación en época medieval no obedeció sólo a fines defensivos, sino también productivos, y llama la atención sobre diferentes aspectos de su poblamiento, por ejemplo las cuevas ${ }^{12}$.
A pesar de todo el cambio que supuso el trabajo de Manuel Pérez Villamil y de Juan Catalina García, por distintos motivos -fundamentalmente ideológicos-, todo el periodo anterior a la Reconquista, queda ensombrecido en sus obras, reducido a una especie de interrupción del curso natural de la historia. Una historia que, de hecho, empieza en el momento de la conquista feudal, y cuando se refiere a periodos anteriores es para explicar algunos ataques leoneses y castellanos o remarcar la posible continuidad de población de religión cristiana (mozárabes) aludiendo a la toponimia y la existencia de algunas iglesias y ermitas.

En cualquier caso, con el trabajo de los dos eruditos se inició una nueva etapa en la historiografía medieval de Guadalajara e influyeron enormemente en obras coetáneas y posteriores (BALLESTEROS, 1991: p. 61), como la tesis de José Antonio Ubierna y Eusa sobre los Fueros de la provincia elaborada en 1889 (UBIERNA, 1917), o el trabajo de Valentín Picatoste sobre la historia política, eclesiástica y monumental de la región, de 1890, (PICATOSTE, 1890), así como en el trabajo de Toribio Minguella, del que hablaremos más adelante (MINGUELLA, 1910). Por citar otro ejemplo de esta influencia, en la primera de las obras que hemos mencionado, al hablar del surgimiento de los pueblos y municipios, se nos plantea el siguiente esquema: su origen es romano, quedó muerto o adormecido durante el periodo godo y finalmente reorganizado en el momento de la «reconquista», sin ni siquiera dedicar una sola palabra al periodo andalusí (UBIERNA, 1917: pp. 22 y ss). O más adelante, cuando se indica que «El Jefe, ó mejor, los jefes de los Municipios, eran los Alcaldes (palabra

\footnotetext{
12 «Situado a la salida de un desfiladero por cuyo fondo corren las aquas del Bornoba, quizá fue establecido para guardar aquel paso, no menos que para utilizar las próximas veguillas. En documentos de la Edad Media de tiempos de Alfonso VII, se cita un lugar llamado Sopeña en situación que pueda corresponder a S. Andrés o a un sitio de sus cercanías. (...) En el desfiladero por donde según he dicho pasa el Bornova, hay abiertas en las rocas desde los tiempos geológicos y en ambos lados de los peñascos, unas cuevas. Es muy grande y curiosa por su configuración y caracteres naturales la que domina la margen derecha del río. Tiene condiciones muy a propósito para que haya servido de morada a los hombres primitivos, que en ella pudieron vivir en situación muy defensiva contra toda clase de peligros. (...) Casi encima de la cuevas y fundados sobre las rocas permanecen los paredones de una torre cuadrada, obra de la Edad Media, que allí se puso para guardar el desfiladero y el paso por él de la gente que transitaba desde las campiñas del Henares y el Bornoba a la sierra de Hiendelaencina y Alcorlo. Aun más arriba de este sitio, en una explanada de no gran extensión, cuyos bordes rocosos y abruptas laderas dan al valle de Alcorlo se ven tosquísimos cimientos que demuestran que la explanada se resguardó en alqún tiempo con una fortificación. Pero no hay restos ni señales que adviertan de la época en que existió aquel puesto militar, que, más cumplidamente que la mencionada torre, puedo guardar el paso del congosto o desfiladero. No sé si se referiría a este puesto la mención del castillo de Alcorlo, pueblo poco distante de él, que he visto en documentos de la Edad Media». (GARCíA, 1906-1911)
} 
árabe, pero institución genuinamente española)» (UBIERNA, 1917: 29). Una de las pocas referencias al periodo andalusí la realiza al hablar del fuero de Aragosa, indicando que «los árabes resistieron por espacio de medio siglo, amparados por algunos castillos y por la aspereza natural del suelo» (UBIERNA, 1917: p. 86).

Paralelamente a estas obras más históricas que arqueológicas, entre finales del siglo XIXy principios del siglo XX, en la Península Ibérica se produce una revalorización por lo árabe, destacando en este sentido las personalidades de Francisco Codera, Manuel GómezMoreno González, o su hijo Manuel GómezMoreno Martínez, y un poco más tardíamente Leopoldo Torres Balbás (ZOZAYA, 2012). Es ya relativamente frecuente encontrar alusiones a restos medievales en publicaciones y relatos de finales del siglo XIX, pero sobre todo en los inicios del siglo XX, referentes a diferentes puntos de la provincia, incluyendo el sector noreste que nos interesa. De entre todos, conviene destacar a Román Andrés de la Pastora, miembro de la Real Academia de la Historia, que recogió un gran volumen de notas que sirvió de base a Minguella para la redacción de su Historia de Sigüenza (MINGUELLA, 1910). Pero sobre todo, el más destacado de entre los arqueólogos del cambio de siglo fue Enrique de Aguilera y Gamboa, más conocido como el Marqués de Cerralbo, «pionero de la arqueología en estas tierras interiores del Tajo», cuyos escritos «reflejan esa perspectiva decimonónica que aúna la historia romántica, con un eruditismo manifiesto que se concreta en una amalgama de datos arqueológicos, geológicos, geográficos y costumbristas» (BUENO, BARROSO y JIMÉNEZ, 2002: p. 49).

Al Marques de Cerralbo le corresponde el mérito de llevar fuera de las fronteras de España el conocimiento de los restos arqueológicos aquí existentes, bien a través de sus intervenciones en congresos internacionales de antropología y arqueología prehistórica, o bien por su amistad con algunos famosos investigadores europeos del momento, además de que se le ha reconocido como el precursor directo de muchas de las ideas y trabajos que desarrollarán posteriormente Pere Bosch Gimpera, Emilio Cabré o Blas Taracena (una completa biografía sobre él en GARCÍA-SOTO, 1999). Es a partir de sus trabajos cuando se abandona la tendencia decimonónica de recoger únicamente los hechos más notables o las historias de las localidades más importantes de la provincia, como Sigüenza en nuestro caso, pasando a referir de un modo más amplio la historia de pequeños pueblos, de amplios espacios comarcales o de yacimientos concretos donde se encuentran restos dignos de reseñar. Muestra de ello en Guadalajara fue el inicio del interés por Recópolis (CUADRADO, 2002: pp. 106-109). No obstante, a pesar de la enorme importancia que los trabajos del Marqués de Cerralbo tuvieron ${ }^{13}$, el impacto que tuvo en el conocimiento del periodo andalusí, y en general para todo el medievo, fue prácticamente nulo, en parte, debido al mayor interés puesto en los periodos protohistórico, romano y visigodo, como denota el inventario de su colección (ARGENTE, 1977: JIMÉNEZ y GARCÍA-SOTO, 2008) ${ }^{14}$.

13 Dos son las obras de referencia por antonomasia. La primera es una obra inédita: (AGUILERA, s.f.) Consta de cinco volúmenes: I dedicado a Torralba, II dedicado a yacimientos neolíticos, III dedicado exclusivamente a la necrópolis de Aguilar de Anguita, IV necrópolis celtibéricas y $V$ dedicado a Arcóbriga romana. La segunda obra de referencia que podemos citar, esta si publicada, es su estudio arqueológico sobre el valle del río Jalón, en la vecina provincia de Soria en un territorio limítrofe con el estudiado por nosotros, y que fuera el discurso de entrada del Marqués de Cerralbo en la Real Academia de la Historia (AGUILERA, 1909). En esta obra se muestra claramente la preferencia por los restos de la Edad del Hierro. No obstante, hay que anotar las referencias que hace a la existencia de cuevas en donde se encontraron inscripciones árabes (Cueva Labrada en el municipio de Jubera, pp. 166170) y toda la explicación, eminentemente histórica y cultural que trata de dar, intentando relacionar la cueva con el enterramiento de algún caudillo importante.

14 Se trata de un inventario que Juan Cabré realizó entre los años 1922-1926, que consta de 168 folios y 5965 piezas arqueológicas, siendo el $50 \%$ de los yacimientos pertenecientes a Guadalajara (un total de 46). La mayor parte de los materiales provienen de necrópolis o yacimientos llamados «acrópolis», generalmente de la Edad del Hierro. Del marco territorial en el que nos centramos, se citan yacimientos arqueológicos en El Atance, Carabias, Alcolea de las Peñas, Tordelrábano, y el cerro del Mirón de Sigüenza, además de dos zonas próximas que también son de nuestro interés, como Torresaviñán, y Aguilar de Anguita. Que sepamos, en toda esta colección no hay conocimiento de piezas de los siglos plenomedievales, aunque una revisión de conjunto está aún pendiente de hacer. 
En cualquier caso, hay un cambio de tendencia. Aunque siga sin estudiarse lo medieval, ahora se han vuelto los ojos a la prehistoria, lo cual denota cómo el interés por construir una identidad va cambiando a lo largo del tiempo. Este viraje, liderado por el Marqués de Cerralbo, marca las líneas maestras del tipo de investigación histórica que se practicará desde principios del siglo XX, cobrando una mayor fuerza la arqueología, aunque en lo sustancial, el discurso histórico no se altere demasiado (CUADRADO, 2002: p. 109; BALLESTEROS, 1991: p. 63).

A inicios del siglo XX, dos son los más destacados historiadores por el salto cuantitativo y cualitativo que aportaron al conocimiento histórico de la región. Nos referimos a Fray Toribio Minguella y Arnedo y a Francisco Layna Serrano. Ambos tuvieron una eminente orientación documentalista ${ }^{15}$, con inclinación a escribir historias a modo de crónicas de los lugares investigados, basándose fundamentalmente en la información de archivos, aunque ambos incluyeron importantes anotaciones sobre las edificaciones que se conservaban.

Junto a los dos ya mencionados, a principios del siglo XX también sobresale la figura de Antonio Pareja Serrada, predecesor de Layna Serrano en el cargo de Cronista Provincial (HERRERA, 1987: pp. 350-351). Se propuso escribir la Historia de la Provincia de Guadalajara en diversos tomos, aunque finalmente sólo publicó los dos primeros sobre Guadalajara y Brihuega en 1915 y 1916 respectivamente. Posteriormente publicó la que se ha erigido como su obra más importante, la conocida como Diplomática Arriacense (PAREJA, 1921), una abundante documentación de diversos archivos sobre numerosos pueblos y lugares de la provincia que constituía, como él mismo afirma en el prólogo, la base documental de los tomos que nunca llegó a publicar (PAREJA, 1921: p. 9). En este libro volvemos a ver, grosso modo, el mismo planteamiento que en los autores anteriores, partiendo de la idea de que «en la Historia de España nos es preciso tener en cuenta que sus poblados comenzaron a gozar vida propia en la época de la reconquista...» (PAREJA, 1921: p. 10). O más adelante, cuando afirma que:

La invasión sarracena, el sangriento fanatismo del vencedory la constante lucha religiosa que existía entre las razas africana y visigoda, mermaron considerablemente la población cristiana, aun aceptando ésta la condición de mozárabe; por esta razón era indispensable inclinar la inmigración hacia los pueblos reconquistados dando á sus moradores ciertos privilegios que se llamaron cartas-puebla ó cartas de población y que, preventivamente, hicieron el servicio de fueros regulando los derechos económicos de los nuevos vecinos. (PAREJA, 1921: 193)

En cualquier caso, dejando a un lado todas estas consideraciones que son más juicios de valor que análisis históricos, la importancia de esta obra es enorme. Comenzando por el siglo XI y llegando hasta el XIII, va a ir transcribiendo y traduciendo más de 120 documentos entre diplomas, donaciones, cartas, privilegios y fueros; añadiendo, además, algunos comentarios respecto a su autenticidad, fecha o firmantes que son de gran valor.

Pero desde un punto de vista estrictamente arqueológico, podemos afirmar que la arqueología, y especialmente la dedicada al periodo medieval, sufre en estos momentos un retroceso importante, faltando todo tipo de excavaciones y desapareciendo casi totalmente las historias de los núcleos urbanos basadas en sus restos arqueológicos ${ }^{16}$, o como mucho, basándose únicamente en la descripción de los edificios en pie, práctica consolidada en el marco de la Ley de Patrimonio de 1933 (CUADRADO, 2002: p. 109). La única obra digna de referencia de estos años, que palió la carencia

15 Transcribieron y publicaron documentos luego perdidos durante la Guerra Civil o dispersos en distintos archivos, lo que otorga mayor valor si cabe a sus obras.

16 A pesar de que, por ejemplo, en la vecina Medinaceli se habían practicado ya intervenciones arqueológicas tanto en la propia villa como en el cerro de Villavieja, que si bien no habían tenido como objetivo localizar los restos árabes, sí que habían sido localizados y estudiados tanto cerámicas o monedas, como estructuras (MÉLIDA, 1926) 
de publicaciones arqueológicas, es la Guía Arqueológica y de Turismo de la Provincia de Guadalajara, de Julián García Sáinz de Baranda y Luis Cordavias (GARCÍA y CORDAVIAS, 1929) ${ }^{17}$, donde, siguiendo el mismo método de crónica y ordenándolo por municipios y partidos judiciales, estos autores exponen los yacimientos arqueológicos que se conservan en algunos pueblos. En esta obra el interés por el periodo árabe es muy notorio (y más teniendo en cuenta el contexto de desinterés a este respecto), acudiendo no solamente a información proporcionada por los documentos, sino al estudio de los restos emergentes, o incluso, al recurso de la toponimia ${ }^{18}$. De esta obra, a nosotros nos interesa especialmente las páginas dedicadas a Atienza, Sigüenza y los pueblos de sus partidos judiciales (GARCÍA y CORDAVIAS, 1929: pp. 55-64, 65-76, 205-230 y 231-246 respectivamente)

En lo que se refiere al discurso histórico creado, sin embargo, no es mucho lo que cambia respecto a épocas anteriores, resumiéndose el proceso como una especie de lapsus del curso normal de los acontecimientos. Así, podemos leer:

Fue nuestra villa la antigua Atincia de los romanos, y caída en poder de los hijos del Islam, Alfonso III, en una de sus rápidas excursiones en terrenos de la morisma llegó a tomarla; en 985, Almanzor la castigó ferozmente por su levantamiento y así continuó hasta que Alfonso VI sacudió su yugo apoderándose de ella en 1083, aunque antes pasajeramente en 1012 la hubo liberado el conde Sancho García. (GARCÍA y CORDAVIAS, 1929: p. 57)
O en el caso de Sigüenza, cuando dice que:

Pasó sobre ella la invasión bárbara, y cuando se había querido reponer de sus devastaciones, la rota del Guadalete y la ola arrolladora de los hijos de la Media Luna, dió con sus huestes en los muros de Sigüenza, la que no pudiendo resistir su empuje, se entregó a Tariky Muza en 713. Continuó bajo la denominación árabe, y aunque Alfonso III, Fernando I el Católico y el Cid Campeador, llegaron hasta ella y la poseyeron brevemente en sus arriesgadas excursiones, Alfonso VI la conquistó nuevamente pero la invasión almorávide le obligó a abandonarla y acudir a Toledo a preparar su ejército, y, por último, Alfonso VIII, en 1124, en 22 de Enero, como afirman el Libro de Fundaciones y el Calendario de la catedral seguntina, volvió a poder de los Cristianos para no volver a salir de su poder. (GARCÍA y CORDAVIAS, 1929: pp. 205-206)

Quizás, una de las cuestiones más interesantes sea la constatación de una interpretación histórica a partir de datos fragmentarios. Nos referimos al supuesto cambio de manos tanto de Sigüenza como del castillo y villa de Atienza, en varios momentos pero sobre todo a finales del siglo $X$, pasando a manos de los cristianos, y después recuperada por parte de los andalusíes ${ }^{19}$.

Del periodo andalusí, a nivel histórico, apenas si encontramos información, más allá de, por ejemplo, la posible existencia de mozárabes o incluso un obispo, bajo la dominación árabe ${ }^{20}$.

17 Debemos señalar que su concepción del sentido de la palabra «arqueología» está más próximo al relato que hoy en día es propio de historiadores del arte, deteniéndose en prolíficas descripciones artísticas, y tipológicas, con todo lujo de detalles de medidas y formas, sobre todo al hablar de los templos e iglesias. Aún así, son de gran valor las menciones a yacimientos arqueológicos.

18 En el estudio que hace de la ciudad de Guadalajara, por ejemplo, no solo enumeran las iglesias que en un pasado pudieron ser mezquitas, sino que incluso relacionan el nombre de dos barrios de la ciudad, Budierca y Alamín, con su posible origen musulmán (GARCÍA y CORDAVIAS, 1929: p. 22)

19 Se trata de una explicación deficiente desde nuestro punto de vista, porque no tiene en cuenta la propia organización social del espacio fronterizo, ni la relación de sus habitantes con el poder central. Pensamos que estos hechos deben interpretarse más bien como una cierta independencia de las élites locales respecto al poder Omeya-Amirí, momentos en los que no tendrían problema en buscar alianzas temporales con los otros grandes poderes político-militares del entorno, como la corona de León o la de Castilla.

20 «De esta época hasta la reconquista de la ciudad por Alfonso VI, no se conoce el nombre de los obispos seguntino dispersos de su diócesis por la invasión sarracena; sólo uno es citado por San Eulogio en su carta de gratitud a Wicesindo, obispo de Pamplona, y menciona como obispo seguntino a Sisenando.» (GARCÍA y CORDAVIAS, 1929: p. 206) 
En este libro se refiere la existencia de algunos restos arqueológicos que hoy en día sabemos que tienen fases de ocupación andalusíes, pero que en esta obra, sin embargo, no se da ningún tipo de cronología, como por ejemplo la Peña del Castillo en Alcolea de las Peñas o las tumbas excavadas en la roca del despoblado de Morenglos ${ }^{21}$; las torres del Congosto en Alcorlo ${ }^{22}$ y de Estriégana ${ }^{23}$; el castillo de Galve de Sorbe ${ }^{24}$; o la cueva de Olmedillas ${ }^{25}$. De otros yacimientos sí que da algunas precisiones cronológicas, como ocurre en el caso del castillo de Inesque en Angón ${ }^{26}$, mientras que en otras ocasiones hace referencia a posibles cronologías de manera indirecta, como Castilviejo de Guijosa ${ }^{27}$ o en la Ermita de los Quintanares de Horna ${ }^{28}$. De los lugares que, con más o menos seguridad, estuvieron ocupados en distintas épocas, sólo presta atención a sus fases más antiguas, como en la torre de San Andrés del Congosto ${ }^{29}$ o en el cerro de Villavieja de Sigüenza ${ }^{30}$. También llaman la atención algunas ausencias, como que no cite apenas información de interés sobre el castillo de Sigüenza ${ }^{31}$, o que no mencione la torre de Anguita (GARCÍA y CORDAVIAS, 1929: p. 233) ni la de Barbatona pero sí su ermita (GARCÍA y CORDAVIAS, 1929: p. 230), a pesar de ser dos elementos notables en el paisaje de ambos pueblos, y que en obras anteriores sí eran referidos (vid. supra). Quizás su posible origen andalusí, o en general el desinterés por el periodo medieval más reciente, hicieron que estos yacimientos, así como datos procedentes de los anteriormente señalados, pasaran totalmente desapercibidos.

\section{De los años treinta: el franquismo, la construcción de la identidad nacional- medieval y el olvido del periodo andalusí}

Con posterioridad a la Guerra Civil se abre un periodo de reactivación de la arqueología en la provincia y muy especialmente de impulso en el estudio del periodo visigodo (CUADRADO, 2002: p. 110). En Guadalajara, el interés por lo visigodo cobró relevancia con la aparición del libro de Zeiss sobre los ajuares de las necrópolis visigodas que incorporaba noticias procedentes de las necrópolis de Alarilla, Villel de Mesa y Palazuelos, ésta última dentro del territorio objeto de interés (ZEISS, 1934). Sin embargo, el periodo andalusí siguió en el olvido e, incluso, en el contexto de apogeo del «españolismo nacionalcatólico» y el máximo apogeo de la noción de la Reconquista, la historiografía académica se nutrió

21 «En lo alto de un peñasco llamado "Peña del Castillo", se muestran restos de muralla y en dicha montaña hay una roca vaciada interiormente a pico, en la que existen dos habitaciones que sirvieron antiquamente de cárcel» y más adelante "Existen también en el término varias cuevas, que parece fueron habitadas en tiempos prehistóricos y en el despoblado de Morenglos se han descubierto varias sepulturas sobre roca de arenisca» (GARCÍA y CORDAVIAS, 1929: p. 66)

22 «En el sitio denominado "El Congosto", se conservan aún restos de una torre de señales, que servía de intermediaria entre el castillo de Jadraque y el de Atienza, llamándose a dicha torre "el Castillo"» (GARCÍA y CORDAVIAS, 1929: p. 67)

23 «... y en el sitio denominado "La Torrecilla" existen restos apreciables de un torreón» (GARCÍA y CORDAVIAS, 1929: p. 235)

24 "Tuvo un célebre castillo, situado a unos 400 metros del N. O. de la villa, cuya torre se conserva en buen estado, no así sus defensas que se hallan todas derruidas» (GARCÍA y CORDAVIAS, 1929: p. 70)

25 «En el término existe una curiosa cueva, denominada "Guarzal”, en la que se han encontrado restos de cerámica antigua, teniendo huellas de haber estado habitada» (GARCÍA y CORDAVIAS, 1929: p. 240)

26 «En el año 1581 existía en su término el castillo de Inesque, como a media legua del lugar» (GARCÍA y CORDAVIAS, 1929: p. 68)

27 "En el sitio llamado "Castilviejo" se ven las ruinas de un castillo en lo más alto de un cerro (...) Cerca de él se ha encontrado un yacimiento prehistórico, quizás celtibérico, del que se han sacado dagas, rejas de arado, lanzas, silez, hachas y monedas de oro del tiempo del emperador Trabajo y que contiene algunas tumbas» (GARCÍA y CORDAVIAS, 1929: p. 235)

28 «Cerca de este pueblo está la ermita de Quintanares (...) y en sus proximidades fue encontrada una moneda de oro del emperador Valentiniano en 1867» (GARCÍA y CORDAVIAS, 1929: p. 236)

29 «La que fué torre de San Andrés del Congosto estuvo edificada sobre rocas, bajo las cuales se abren grandes cavernas naturales que han debido de servir de morada a pueblos prehistóricos de la época paleolítica y neolítica» (GARCÍA y CORDAVIAS, 1929: p. 73)

30 Del que tenemos serias sospechas fue ocupado también en época andalusí, como exponemos más adelante. «La ciudad celtíbera estuvo edificada en el cerro llamado de Villavieja, donde debió estar asentado el castro defensivo de la ciudad, del que todavía se ven escombros en su emplazamiento» (GARCÍA y CORDAVIAS, 1929: p. 225)

31 «... en su desmochado castillo, palacio a su vez de los obispos Señores de Sigúenza, del que sólo quedan restos habitables de sus torres y murallas, con su gran patio de armas (...) Sus robustas construcciones denotan ser en su mayoría del siglo XIV, notándose en algunas partes, tener manifestaciones anteriores». (GARCÍA y CORDAVIAS, 1929: p. 226) 
de prejuicios históricos acerca de al-Andalus, como fue, por ejemplo, el negar la propia islamización (GARCÍA SANJUÁN, 2011: pp. 65-68, 2012: 82-87 y 2013: 70-143).

Muestra del desinterés por el periodo andalusí y la preferencia por otros periodos son los resultados de las primeras investigaciones en la Cueva de los Casares. Se trata de un yacimiento situado en Riba de Saelices, dentro del parque natural del Alto Tajo, al sureste del territorio objeto de estudio ${ }^{32}$. Se compone de tres partes, una profunda cueva de más de 250 metros de longitud que alberga pinturas y grabados rupestres de tipo esquemático con figuras antropomorfas y zoomorfas; los restos de un poblado en la ladera que asciende desde el fondo del valle hasta la cueva; y un torreón encima de ésta, en la superficie aplanada en la que culmina la sierra en la que está enclavada. Aunque hay algunas referencias a la misma desde el siglo XIX (MADOZ, 1845-1850: t. II, p. 259), no es hasta 1933 cuando se hace mención explícita a sus grabados y cuando comienzan las investigaciones de la mano de Juan Cabré (CABRÉ, 1934). No vamos a ocuparnos aquí de describir los restos arqueológicos, lo que nos interesa señalar ahora es que tanto el poblado que hay en las afueras de la cueva, como el torreón que hay encima son de época andalusí, así como algunos restos del interior de la cueva, como han demostrado investigaciones posteriores (GARCÍA-SOTO, FERRERO y GUILLÉN, 2004). No obstante, en el segundo tercio del siglo XX, cuando se realizaron la mayor parte de las investigaciones, el interés estuvo centrado únicamente en los grabados y pinturas paleolíticas, de las mejores de las conservadas en la Península (ACOSTA, 2003). Pero lo que nos interesa ahora señalar, en este marco historiográfico que estamos trazando, es que en todas las investigaciones que se llevaron a cabo, al menos hasta los años setenta del siglo $X X$, los restos islámicos prácticamente pasaron desapercibidos, a pesar de que el propio Juan
Cabré había señalado la existencia a los pies de la cueva de un poblado islámico del siglo $\mathrm{XI}$, fechado por el hallazgo de una moneda entre los muros derribados así como por algunos restos cerámicos (CABRÉ, 1934: pp. 232-233) ${ }^{33}$. A excepción del torreón, del que sí encontramos algunas referencias (GAYÁ, 1935; posteriormente analizado de nuevo en ALMAGRO, 1976: pp. 296-300), los estudios sobre el interior de la cueva refieren la existencia de una fase altomedieval, pero siempre mal definida y apenas caracterizada. Por ejemplo Ignacio Barandiarán en 1969 explicaba que un sondeo practicado en la entrada de la cueva «ha indicado la presencia de niveles de ocupación humana: son de la Alta Edad Media, de la Edad del Bronce y de aspecto paleolítico, indeterminable aún». (BARANDIARÁN, 1969: p. 158). En una publicación posterior, más amplia, aporta algunos datos más

Las variedades de cerámica que Cabré señaló en el poblado «árabe» de delante de la cueva, coinciden exactamente con las que hemos recuperado en el interior del pozo o aljibe tallado en el suelo del vestíbulo de Los Casares: así los fragmentos "barnizados con verde y tonos melados» (no 412 a 424 de nuestro inventario), los de «barro claro amarillento con pinturas rojizas de carácter geométrico» (no 398 a 400) o los «de barro oscuro con decoración incisa determinando ondulaciones, a veces entrecruzadas» (no 411). De ahí que se pueda mantener la contemporaneidad de la fabricación y uso de ese pozo con el despoblado del exterior, indudablemente medieval y caso -como supone Cabré«árabe» y del siglo XI. (...)

Los testimonios cerámicos de la Alta Edad Media aparecen en varios lugares revueltos de la cueva pero se concentran especialmente en el interior del pozo o aljibe de su vestíbulo. Son absolutamente asimilables a los que Cabré señaló en el

32 La cueva se declaró Monumento-Histórico en 1935.

33 Debemos señalar que apenas un año antes Francisco Layna había datado el despoblado como de época ibérica basándose en el aparejo de los muros casi ciclópeos de algunas construcciones (LAYNA, 1933). 
poblado de «Los Casares» y dató en el siglo

XI (BARANDIARÁN, 1971: pp. 74-75 y 83)

A pesar de la excepcionalidad de este yacimiento, poco más información se extrajo del mismo durante los años centrales del siglo $X X$, debiendo esperar prácticamente hasta el cambio de milenio para que se diera a conocer realmente la fase andalusí de este asentamiento, uno de los pocos excavados en la provincia de esta naturaleza como explicaremos en los últimos apartados de este trabajo.

Sobre la cueva de los Casares también se ocupó en un primer momento el que es uno de los historiadores más reconocidos de la provincia y al que ya hemos hecho referencia anteriormente: Francisco Layna Serrano (la mejor biografía sigue siendo la de GISMERA, 2002). Desde 1932 y hasta mediados de la década de los sesenta publicó cerca de cincuenta obras, combinando trabajos monográficos sobre determinadas poblaciones, monasterios o monumentos, con estudios a nivel provincial recopilando informaciones de carácter más amplio sobre algún determinado aspecto. En concreto cuatro pueden ser consideradas como sus obras principales: un trabajo monográfico dedicado a los Castillos de Guadalajara en donde recopiló información que podemos considerar arqueológica junto con abundantes datos procedentes de fuentes documentales; un trabajo sobre la Arquitectura Románica de la provincia; su gran obra sobre el periodo de Los Mendoza, centrada fundamentalmente en la capital, y finalmente una Historia de la villa de Atienza desde sus orígenes prehistóricos hasta bien entrada la época moderna (LAYNA, 1933b, 1935, 1942 y 1045) ${ }^{34}$.

Gracias a los sustanciosos prólogos que incluía en sus obras, es posible rastrear su pensamiento a nivel historiográfico. Aunque no se ocupó nunca de manera exclusiva por el periodo andalusí, sí que aportó interesantes reflexiones a partir de los escasos conocimientos que se tenían en la época, y señaló algunas ideas que posteriormente han tenido gran relevancia, tanto a nivel metodológico, como a nivel interpretativo. Así, por ejemplo, indicó como era posible rastrear el periodo islámico a partir de las informaciones contenidas en los documentos que hablan de ataques cristianos a la región (LAYNA, 1942: p. 24). También sacó a colación como la importancia de uno u otro núcleo de población durante la etapa de al-Andalus podía determinarse por el número de personajes ilustres que en él hubieran nacido o ejercido, tal y como ocurría con la ciudad de Guadalajara (LAYNA, 1942: p. 24, ideas luego recuperadas por MARÍN, 1995). Continuó con la tónica general de dar primacía a las poblaciones cristianas que quedaron bajo el dominio islámico, señalando la permanencia de estos grupos en determinadas regiones:

La fertilidad de la campiña del Henares
determinó a muchos cristianos a doblar la
cerviz bajo el yugo musulmán con tal de
salvar su hacienda y así vivieron numero-
sas familias de mozárabes en Guadalaja-
ra, como por la misma razón se quedaron
allí abundantes familias moras a las que
se llamó mudéjares, después de la Recon-
quista; los cristianos sometidos eran respe-
tados en sus usos, costumbres y religión...
(LAYNA, 1942: pp. 24-25) ${ }^{35}$

También se pueden encontrar en su obra reflexiones de gran interés, pero que parecen haber pasado desapercibidas hasta fechas muy recientes. Valga la siguiente referencia como ejemplo, en la que apunta al alto grado de rebelión entre los habitantes de la frontera media frente a Córdoba, llegando a utilizar términos como «poder central» e intuyendo, por lo tanto, la existencia de otros poderes

\footnotetext{
34 De sus propios escritos se sabe que tenía proyectadas monografías sobre los principales núcleos de la provincia, no llegando a publicarse más que los de Guadalajara y Atienza, y otro sobre Cifuentes, en el que indica que quedaban pendientes: «sendos libros sobre Sigüenza, Pastrana, Brihuega, Cogolludo, Alcocer, Tendilla, Mondéjar y alguna otra villa histórica de la provincia» (LAYNA, 1955: p. 5).

35 En otros trabajos insiste en esta idea de que la población «autóctona» era superior en número que la de los dominadores árabes y beréberes: «...los árabes y berberiscos eran proporcionalmente muy pocos en relación con la población indigena que habian de mantener sumisa, y eso sólo pudieron conseguirlo gracias a la presencia de fuertes contingentes armados y sabiamente distribuidos con tal fin...» (LAYNA, 1933: p. 24)
} 
locales (ideas luego defendidas en MANZANO 1991 o GARCÍA-CONTRERAS, 2016a):

\begin{abstract}
[Alfonso VI] tras varios años de intervenir en sus discordias civiles procurando debilitar el poder de los musulmanes y haciendo pagar su interesada protección con la entrega sucesiva de las principales plazas fuertes, entrega no siempre pacífica pues la disciplina entre los árabes estaba muy relajada, a menudo el Poder central no era obedecido y el que podría llamarse partido de oposición negaríase en muchos casos al cumplimiento de las órdenes de aquél... (LAYNA, 1942: p. 25)
\end{abstract}

Aunque sobre la región de estudio destacó siempre su alto valor geoestratégico y lo fortificados que estuvieron los pasos del sistema central y los valles fluviales ${ }^{36}$, señaló también la posibilidad de que las torres cumplieran otras funciones más allá de las exclusivamente fronterizas, aspectos que autores más recientes han vuelto a recuperar (BUENO, 2016; GARCÍA-CONTRERAS, 2013a, 2015, 2016a):

Esas «torres» se destinaron en la alta Edad Media (como también siglos antes) a guardar las costas, fronteras y pasos estratégicos por desfiladeros angostos, multiplicándose para vigilar el terreno o comunicarse entre sí o con fortalezas distantes, mediante ahumadas diurnas y luminarias de noche; pero en aquellos tiempos rudos, no existía la seguridad personal, y la «torre fuerte» hubo de ser el complemento de muchas construcciones civiles, sorbe todo en las quintas o alquerías campestres, precursoras no pocas de los feudos o señoríos; andando los años estas torres civiles fueron desapareciendo a medida que se consolidaron las organizaciones comunales para la mutua defensa, que adquirieron vida propia los municipios, o que la sociedad fue disciplinándose sometida al Derecho y a la autoridad del Rey, guardador de aquel. Pero no todas esas torres fueron abandonadas; muchas formaron un núcleo de atracción a cuya sombra protectora surgió un pueblo constituido por los colonos o vasallos del señor y otras fueron sustituidas por su legitimo heredero, el castillo señorial. (LAYNA, 1933: p. 25)

Si la obra de Francisco Layna fue una de las más importantes del siglo XX en lo que a historia se refiere, para este mismo momento debemos destacar también el inmenso trabajo de otro investigador: la del geógrafo Antonio López Gómez (una biografía en ROSSELLÓ, 2004). Su labor en la provincia de Guadalajara se centró sobre todo en la serranía norte y, muy especialmente, en el entorno de Atienza, tema de su tesis doctoral y sus primeros estudios (LÓPEZ, 1966, 1967, 1969, 1974). No se dedicó en ningún momento en exclusiva al periodo andalusí que nos ocupa, ya que en realidad no estudió ningún período histórico concreto, pero recurrió asiduamente a los siglos XVI y XVIII, por tener documentación de referencia que le permitía trazar una evolución histórica del paisaje dentro de su concepción de lo que debía ser la Geografía Histórica (LÓPEZ, 1984, 1990, 1993, 1997), llegando a ocuparse incluso de las salinas históricas de la región (LÓPEZ, 1970), algo que indudablemente a marcado concepciones más recientes de la arqueología del paisaje (MALPICA et alii, 2008, 2011a, 2011b; GARCÍA-CONTRERAS 2009, 2012a, 2013a). Además, señaló algunas ideas que son dignas de tener en cuenta, por ejemplo cuando se esfuerza por entender si una mayor densidad de topónimos de origen árabe permitiría rastrear una densidad de poblamiento que fuera la causante de las transformaciones en el medio físico. Así, señala que:

\footnotetext{
36 «... la provincia de Guadalajara tuvo considerable importancia estratégica, pues cruzando los puertos a uno y otro lado de Atienza los leoneses y castellanos solían invadir la región del Tajo, o las huestes agarenas estragaban los campos del Duero en sus violentas reacciones ofensivas. Así, los musulmanes defendieron la bajada del valle del Sorbe y su puente, con el enriscado castillo de Beleña; el peñón de Atienza que otea las barrancas que bajan de la montaña de Miedes, sustentó en aquella edad remota una fortaleza poderosa que aun maltratada por Almanzor puso miedo en el bien templado corazón del cid, igual que el cercano castillo de Sancti luste (Riba de Santiuste) guardador de la vaguada procedente de los altos de Paredes; a Sigüenza tenían también fortificada, Chadraque y Fita mostraban en lo alto de sus cónicos cerros altivas fortalezas así como Guadalfahara (río de piedras)...» (LAYNA, 1933: p. 20)
} 
En la época musulmana la población debía asentarse principalmente en los valles periféricos, más abiertos y fértiles, mientras que habría escasas aldeas en el escabroso macizo antiguo. A éste corresponde sólo uno de los pocos topónimos, probablemente árabes, conservados (Almiruete); los otros se refieren a las comarcas periféricas: al S. Alcorlo; en el N. Alcolea, Albendiego, el híbrido Villacadima y posiblemente Galve; desde luego sobresale Atienza, cuya fortaleza, en el paso del Duero superior al Henares, alcanzó gran importancia en los siglos X y XI, cuando la frontera entre la España Cristiana y AlAndalus se acercó a la cordillera Central. (LÓPEZ, 1966: 395)

\section{El "giro material» en la historiografía medieval y el despertar de al-Andalus: los años setenta, ochenta y noventa}

Los años setenta y ochenta van a ser un auténtico revulsivo para el medievalismo peninsular, fundamentalmente por dos motivos: la incorporación al conocimiento histórico de los datos procedentes de investigaciones arqueológicas, en lo que podemos considerar propiamente el nacimiento de la Arqueología Medieval como disciplina (QUIRÓS y BENGOETXEA, 2006; QUIRÓS, 2009; VALOR y GUTIÉRREZ, 2014); y en segundo lugar por el revulsivo para la historia de al-Andalus que supusieron las obras de Pierre Guichard sobre la estructura y organización social de Al-Andalus (GUICHARD, 1976) Si hasta este momento la poca arqueología medieval que se practicaba se dedicaba casi siempre a fechas anteriores al siglo VIII y generalmente a edificios de culto o necrópolis, a partir de ahora va a ampliarse el ámbito de estudio, comenzando a incorporarse excavaciones en castillos y ámbitos urbanos de época andalusí y llegando a definir cuáles debían ser los principales temas de estudio de la arqueología medieval -cerámica, metales, fortificaciones, torres, caminos, casas, necrópolis, cenobios y ciudades abandonadas- que la diferenciaba de otras disciplinas como la historia del arte ( (ZOZAYA, 1970: p. 346). Aunque el noreste de Guadalajara no se verá incluido directamente en este nuevo interés por al-Andalus hasta algunos años más tarde ${ }^{37}$, sí que se vio favorecido por el desarrollo de investigaciones arqueológicas en lugares cercanos como Alcalá de Henares (ZOZAYA y FERNÁNDEZ, 1983), el castillo de Gormaz en Soria (BANSK y ZOZAYA, 1984; ZOZAYA, 1988), en Vascos (Toledo) (IZQUIERDO, 1979 y 1982) así como también en Recópolis, en la parte suroeste de Guadalajara (FERNÁNDEZ-GALIANO, 1977; OLMO, 1983, 1988a, 1988b). Todos estos estudios supondrán un acicate para que se renueve el interés por los restos materiales islámicos y en general el estudio histórico de toda la Marca Media (ZOZAYA, 1991; RETUERCE, 1995: pp. 100-106).

Llama la atención que las mejores referencias al periodo andalusí, dada la carencia de estudios hasta este momento, debamos buscarlas en las introducciones o capítulos preliminares de las obras que se van a dedicar precisamente al periodo posterior (por ejemplo, GONZÁLEZ, 1975) ya que tenemos que esperar a mediados de los años ochenta para que se publiquen los primeros estudios específicos sobre poblamiento andalusí en la zona (PAVÓN, 1984; HERRERA, 1985). También vamos a encontrar un cierto interés durante estos años por los pasajes de algunos documentos cristianos que, narrando ataques a la frontera, van a mencionar algunos sitios de difícil identificación toponímica en la actualidad. Sobre todo, es lo que ocurre con un ataque de Ordoño II en el año 921 descrito en la Historia Silense por Sampiro (ANÓNIMO, 1959: p. 164), en el que se mencionan sitios con el nombre de «Sintila», «Sarmalon», «Eliph», «Palmacio», «Castellion» y «Magnanza». Por el itinerario del ataque y otros datos de contexto del documento, éstos se sitúan al sur

\footnotetext{
37 En la obra de Guichard, por ejemplo, el territorio de Guadalajara no aparece referenciado, salvo al hablar de una de las tribus beréberes, los Banū Salīm, de los que dice que pertenecían al clan de Sinhāŷa o de Masmūda y dominaron las tierras de Guadalajara y Medinaceli así como las zonas que se hallaban más directamente en contacto con los países cristianos, como las tierras de Ateca y Soria (GUICHARD, 1976: pp. 404-405)
} 
del Duero, pasado el Sistema Central, y antes de llegar al Tajo, es decir, en la zona del Alto Henares que nos ocupa. Aunque sobre ello se llamó la atención en algunas obras anteriores, especialmente sobre la potencialidad del uso de estas referencias para conocer el pasado andalusí (GARCÍA, 1894: p. 17; LAYNA, 1942: p. 24; PÉREZ DE URBEL, 1969: p. 268), es ahora en la década de los ochenta sobre todo cuando renace el interés por estos topónimos (SÁENZ, 1984: pp. 660-661; SEVILLA, 1985). Aunque estos estudios no están realizados, en su mayoría, por especialistas en árabe, ni en al-Andalus en términos generales, ni siquiera en toponimia, $y$ en parte es por ello por lo que en fechas recientes se ha vuelto sobre el tema (RANZ y LÓPEZ, 2002), sí que fueron interesantes pues a partir de ellos se rescató, en parte, el interés por los siglos centrales de la Edad Media.

Este interés por el periodo andalusí al que nos referimos puede, en parte, justificar la aparición de uno de los primeros trabajos dedicados monográficamente al periodo islámico en el territorio de Guadalajara. Se trata de un artículo de Antonio Herrera, cronista oficial de la provincia, aparecido en la revista Wad-al-Hayara (HERRERA, 1985). Este trabajo adolece de un punto de partida más teórico que empírico, enmarcado en toda una tradición historiográfica anterior, y que contiene un doble vicio: considerar el centro de la península Ibérica como un desierto demográfico con anterioridad a la conquista castellanoleonesa, o bien resaltar el papel defensivo de todos los posibles asentamientos que se localicen, sobredimensionando el papel de la frontera (una primera crítica a este trabajo en MALPICA y GARCÍA-CONTRERAS, 2010: pp. 305-306). Así lo expresa el propio autor:

Las marcas (en árabe «Thugur») eran totalmente distintas en cuanto a consideración territorial de las coras (en árabe "Kuwar») o provincias del interior, siempre más seguras y prósperas. Su población, sus estatutos jurídicos y sociales, sus formas de vida, eran en todo diferentes a las de zonas más meridionales. En ellas mandaba un caíd ("qa'id») y estaban, eso es seguro, muy escasamente pobladas, casi desérticas en algunas partes (...) En este sentido, consideramos que la Marca Media en su distrito de Guadalajara fue siempre un territorio de escasa población, tan solo ocupado por destacamentos militares, y con ciertos núcleos de población (Guadalajara, Alcalá, Sigüenza, Medinaceli) un tanto más densos, pero siempre en grado escaso (HERRERA, 1985: p. 14)

Y más adelante, insiste Herrera Casado:

Una vez repasadas las ciudades, fortalezas y torreones vigías sobre la línea del Henares, hemos de terminar considerando la existencia de otros puestos de vigilancia, más aislados, sobre los valles de los ríos serranos que abocan por su orilla derecha en el Henares. Territorios éstos que, durante los tres siglos de existencia de la Marca Media, estuvieron prácticamente desiertos, tan sólo ocupados por las mínimas guarniciones militares encargadas de custodiar los diversos torreones y puntos estratégicos... (HERRERA, 1985: p. 22).

Se trata de una idea persistente en la literatura sobre el poblamiento del centro peninsular en época altomedieval presente incluso en trabajos recientes (VILLAR, 1986; MARTÍNEZ, 2005: p. 74), cuyo origen, se puede rastrear en el tema del desierto en la Extremadura castellana heredera de los planteamientos de Sánchez Albornoz (SÁNCHEZ-ALBORNOZ, 1957), que con anterioridad a Herrera Casado ya había aparecido en la obra de Layna Serrano, y que poco a poco ha sido desmontada por distintos investigadores (ESCALONA, 1989; MARTíN, 2000; ZOZAYA, 2010 así como Basilio Pavón Maldonado o Eduardo Manzano Moreno sobre los que trataremos más adelante). En parte, como decíamos antes, tiene que ver con que el periodo andalusí se estudiaba como un necesario contexto previo a la «reconquista y repoblación», que era lo que realmente interesaba estudiar.

Cabe justificar las palabras de Antonio Herrera por la falta de documentación arqueológica sobre la zona en los momentos en que emite estos juicios, a mediados de los años ochenta, tal y como reconoce el propio autor. 


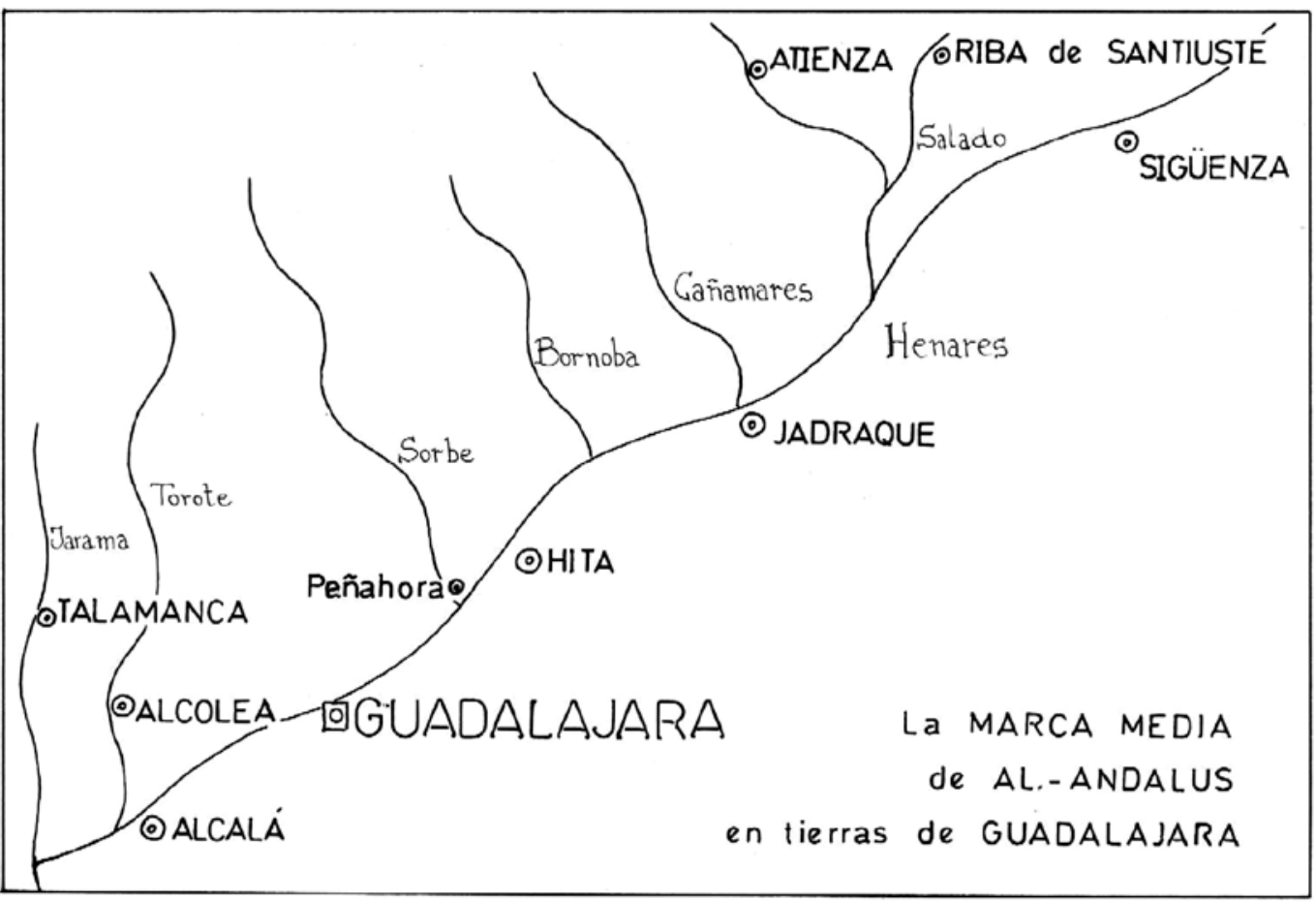

Fig. 2. La Marca Media de al-Andalus en tierras de Guadalajara según Antonio Herrera Casado. (HERRERA, 1985, p. 20)

Lo que ocurre es que en su artículo, aunque reconoce la posibilidad de que se realicen nuevos hallazgos -aunque obviando eso sí muchos de los que ya se conocían en esas fechas, como el de Santamera mencionado anteriormente o el de El Villar de Guijosa dado a conocer dos años antes (MORÈRE, 1983) - no da posibilidad a otro tipo de interpretación, ni siquiera en el caso de que se utilizaran otras fuentes de información:

\begin{abstract}
Esta relación de ciudades, castillos y torreones de los que ha quedado memoria o huella en la línea defensiva del sector oriental de la Marca Media, no agota, por supuesto, el tema de estudio, que sigue abierto, si no a nuevas interpretaciones, sí a nuevos hallazgos, bien documentales o arqueológicos. (HERRERA, 1985: p. 25)
\end{abstract}

En una línea interpretativa similar debemos situar otros trabajos publicados entre los años ochenta y principios de los noventa, que aunque no trataban directamente el período andalusí, se ocupaban de él. Nos referimos a una serie de trabajos que versaban sobre el momento inmediatamente posterior, el de la conquista castellana y sobre todo el de la formación del señorío episcopal seguntino y el desarrollo de su capital, Sigüenza. Debemos hacer referencia a la monografía de Adrián Blázquez sobre el señorío de Sigüenza desde su formación en 1123 hasta su disolución en 1805 (BLÁZQUEZ, 1988) ${ }^{38}$. En ella se plantea que con anterioridad a la creación del señorío episcopal, durante la etapa andalusí lo fundamental es la existencia de un espacio fronterizo amparado por el carácter montañoso y salpicado de castillos, incluyendo a la propia Sigüenza como uno de ellos (BLÁZQUEZ, 1985: p. 36 y 1988: p. 42). Y todo esto sin acudir a ninguna referencia arqueológica ni a fuentes escritas árabes, sino únicamente a documentación cristiana, como el Cantar del mío Cid, la Historia de España del arzobispo Rodrigo, o la documentación recogida por Toribio Minguella a principios del siglo XX proveniente del archivo de la catedral

38 Aunque publicada en 1988, es el resultado de una tesis doctoral leída en la Universidad de Burdeos (Francia) en 1974. 
seguntina. Cita como andalusíes los sitios de Palmaces, Castejón, Riba de Santiuste, Santamera, Huérmeces, o Aragosa, además de Sigüenza, pero ninguno más. Es decir, asentamientos fortificados, pero sin mencionar, pues tampoco era su objetivo, torreones u otro tipo de asentamientos, que sin embargo sí que eran ya conocidos.

Al igual que en el caso anterior, fue un trabajo de tesis doctoral el que realizó Pilar Martínez Taboada, en este caso centrado únicamente en la evolución urbana de Sigüenza y otros treinta núcleos de la provincia (MARTíNEZ TABOADA, 1990 y de nuevo en 2011-2012). Ya en publicaciones anteriores esbozó algunas de las ideas que podemos destacar respecto a la etapa andalusí, precedente de aquella en la que se inicia su mayor interés histórico y artístico. Volvemos a encontrarnos con una forma de entender la historia de al-Andalus en la que vuelve a primar el hecho fronterizo, no ya por encima de otras consideraciones, sino casi como única explicación:

La temprana presencia árabe en la Alcarria, ya que de nuevo la vía romana sirvió de lugar de paso a los nuevos invasores en su camino hacia Zaragoza, no supuso, en un primero momento, una transformación esencial de la herencia urbana, así, sabemos que en Sigüenza continuó la presencia de obispos por lo menos hasta finales del siglo VIII. Pero pronto la situación iba a sufrir un cambio radical, sobre todo al organizar los reinos cristianos en su avance reconquistador, la línea del Duero. Fue entonces cuando toda la Alcarria se convirtió en terreno fronterizo, en la órbita de influencia árabe, desplegándose en sus tierras la «marca media» como parte de las defensas árabes, con la lógica consecuencia de una progresiva despoblación de las zonas que no estaban al abrigo de las fortalezas que lo formaban. (MARTÍNEZ TABOADA, 1985a: pp. 57-58)

Otra de las principal ideas que Pilar Martínez defiende en su tesis es la existencia de una ocupación de importancia durante el periodo andalusí en el núcleo de Sigüenza. Aunque sin aportar ningún argumento documental o material, se afirma con rotundidad que:

\begin{abstract}
Al producirse la invasión musulmana, pronto cayó Sigüenza en manos árabes, dada su situación estratégica, pues la vía romana que cruzaba a su lado fue la utilizada por Tarik y Muza en su avance hacia Zaragoza. Sigüenza fue una de las ciudades romanas de la zona central convertida en ciudad fortaleza al organizarse el sistema de marcas. Los árabes van a potenciar el enclave del castillo levantando la actual alcazaba. A sus pies, y junto al río, permaneció una población mozárabe en torno a su iglesia, y en los primeros siglos junto a su obispo. Las referencias a la existencia de prelados desaparecen a partir del siglo IX, y la ciudad comienza a languidecer hasta convertirse en un villorio cuando Medinaceli se alza como capital de la Marca Media. (MARTÍNEZ TABOADA, 1985b: p. 967)
\end{abstract}

En su tesis defenderá que Sigüenza pasó de ser una ciudad episcopal en época visigoda a convertirse en una aldea dependiente de Medinaceli en época árabe, y todo ello como consecuencia de la organización del sistema defensivo fronterizo (MARTíNEZ TABOADA, 1990: pp. 61-76). En realidad, esta teoría no es exclusivamente suya, sino que estaba ya presente en investigadores locales, influyendo a su vez en aquellos que, como Torres Balbás, trascendieron de los marcos locales para intentar plantear ideas generales sobre la totalidad de al-Andalus (TORRES BALBÁS, 1971: p. 203) ${ }^{39}$. A partir de este momento, esta idea de la ciudad cobra fuerza, y pasa a formar parte de los intentos de explicación de la articulación del poblamiento, a pesar de que no hay evidencia empírica que soporte estas ideas, salvo una determinada manera de interpretar la documentación posterior a la conquista castellana (una crítica en GARCÍA-CONTRERAS, 2014). La autora señala, eso sí, que Sigüenza

39 Torres Balbás no sólo exponía la idea de la ciudad andalusí seguntina, sino que incluso localizaba una población mozárabe junto a la iglesia de origen visigodo, en la zona llana junto al río, donde también la localiza Pilar Martínez. 
sería un tanto diferente y particular frente a otros núcleos urbanos de origen andalusí en la provincia, como Atienza, Zorita, Molina o la propia Guadalajara, ya que no responde a las mismas premisas que las anteriores: su origen no está en una alcazaba, los musulmanes se encontraron ya con un «núcleo urbano perfectamente organizado, y con la existencia de una fortaleza desde la que podrían vigilarlo» (MARTíNEZ TABOADA, 1990: p. 72). Además, se argumenta que los musulmanes permitieron a los cristianos, llamados mozárabes, permanecer en la ciudad e incluso seguir con su culto, localizándose este grupo en torno a la iglesia que pervivía de época anterior, no siendo «hasta mediados del siglo IX, cuando la población mozárabe seguntina comenzase a disminuir, y como consecuencia su sede episcopal desapareciese» (MARTÍNEZ TABOADA, 1990: p. 73).

Estas ideas de Antonio Herrera, Adrián Blázquez o Pilar Taboada chocan, sin embargo, con los resultados de los primeros trabajos de carácter arqueológico dedicados al periodo andalusí que se llevaron a cabo en este sector de la provincia casi de manera coetánea. Nos referimos, fundamentalmente, a los trabajos de Basilio Pavón, Manuel Retuerce, Jesús Valiente y Nuria Morère.

En el año 1983 se publicó la primera Carta arqueológica de la comarca de Sigüenza por Nuria Morère Molinero (MORÈRE, 1983). El trabajo muestra una particular preocupación por los yacimientos medievales, incluidos los andalusíes, algo no frecuente hasta ahora en Guadalajara, como veíamos en páginas anteriores, apareciendo en el libro algunos yacimientos islámicos inéditos y desconocidos hasta la fecha, como por ejemplo el de El Villar de Guijosa (otro distinto al de Castilviejo en el mismo municipio y que mencionábamos páginas atrás). Además, esta obra tiene el mérito de empezar a mostrar un territorio que en la Edad Media no estaba ocupado únicamente por castillos, y cuya explicación, por tanto, no debía ser únicamente fronteriza. Y esta nueva realidad se trataba de mostrar a pesar de las limitaciones que imponía el desconocimiento de los materiales, y por tanto la inseguridad de sus cronologías. En las páginas dedicadas a los hallazgos arqueológicos en torno al río Henares y sus afluentes (MORÈRE, 1983: pp. 23-47) lo primero que llama la atención es la clasificación de los distintos yacimientos en función de sus topografía: en cuevas, en llano, en terreno elevado, torres, enterramientos en roca, hallazgos aislados o materiales procedentes de colecciones privadas. Con ello, fue la primera en apuntar la variedad y heterogeneidad de los yacimientos, aunque en muchas ocasiones sólo se apunte una vaga cronología medieval, lo que se completaba con fotografías de estructuras, materiales cerámicos y cartografías por fases de ocupación ${ }^{40}$. Incluso fue la primera en señalar la posible relación de ciertas tumbas excavadas en roca localizadas en Imón con una posible población cristiana bajo dominio islámico, es decir, colectivos mozárabes (sobre ello profundizó en MORÉRE, 1985). Algunas de las conclusiones a las que llega en su trabajo dan idea del salto cualitativo y cuantitativo que supuso la redacción de esta carta arqueológica, aunque persistían también algunas ideas anteriores:

Durante el período visigodo debió continuar la ocupación de los asentamientos anteriores (necrópolis visigoda de Palazuelos), pero paulatinamente se iría la población trasladando a las laderas de los cerros cercanos buscando una mayor seguridad y estableciéndose en parajes altos y fortificados, al igual que en época prerromana (castro de Castilviejo de Guijosa). De igual modo y ante una necesidad de defensa, se poblaron puntos estratégicos que controlaban las vías de paso como la Cueva Harzal (Olmedillas) y se construyeron torreones de vigilancia de estos caminos (torreones de Barbatona y de Bujarrabal). Estos tres últimos asentamientos, junto con el castillo de Riba de Santiuste, son un claro testimonio de la importante presencia árabe en la comarca seguntina durante la Reconquista, en la que Sigüenza perteneció

40 Por señalar algún defecto de esta obra, diremos que algunas de las coordenadas geográficas que proporciona para los yacimientos son erróneas. 
a la Marca Media y donde, por lo tanto, los árabes desarrollaron una interesante red de fortificaciones. (...) En la Edad Media, la dispersión característica del poblamiento del campo por medio de «villae» desaparece, concentrándose de nuevo la población. Los núcleos ascienden a las laderas y cumbres de los montes, siendo el origen de los actuales pueblos. (...) Así pues, además de las vías romanas ya estudiadas y que muestran el papel central de Sigüenza en esta red vial, aparecen unos caminos secundarios de vital importancia durante la Edad Media, pues fueron fortificados en algunos casos y dejan ver la intensidad del control de los territorios en ese momento. Se reutilizaron las calzadas romanas y se concedió importancia a algunos parajes como confluencia de ríos, de caminos, etc.; todo ello en un afán tanto de defensa de los dominios por los pobladores musulmanes como de conquista por los reyes cristianos. (MORERE, 1983: pp. 60-61)

De esta investigadora, no obstante, quizás lo más destacable sean sus estudios sobre la explotación de la sal en este territorio, que comenzó a realizar en la década de los noventa y que continúan en la actualidad. Es a ella a quien debemos las primeras propuestas de relación de la explotación de la sal con la organización del poblamiento en el norte de Guadalajara; con una preferencia por el periodo romano, pero tratando de abarcar desde la prehistoria hasta finales de la Edad Media (MORĖRE, 1991 y 2008a). No sólo ha establecido esta relación por la proximidad de algunos yacimientos a las surgencias de agua salina en los valles del Alto Henares y el río Salado, sino que además ha indagado y profundizado en el conocimiento de las fuentes escritas de época clásica, rastreando las menciones tanto genéricas a las técnicas, formas de producción y trabajo en las salinas, como a las posibles referencias concretas al territorio seguntino (MORÈRE, 1994, 2002, 2008b, 2011).

Volviendo a retomar el hilo argumental sobre la evolución de la historiografía que tratábamos antes de este inciso sobre la sal, debemos decir que este desarrollo del conocimiento arqueológico de la comarca seguntina en los años ochenta y noventa no fue un caso aislado, sino que coincidió con una renovación de esta disciplina en toda la provincia, en parte gracias a la mayor dotación de medios por parte del Ministerio de Cultura y a la implicación activa de la Diputación Provincial de Guadalajara, a lo que debemos añadir el que las universidades madrileñas o el C.S.I.C. volcaran su interés sobre el territorio guadalajareño para la realización de trabajos de investigación que eran requeridos en los nuevos planes de estudio (CUADRADO, 2002: p. 110). Así se explican cuestiones como el renovado interés por los yacimientos de la provincia - como la necrópolis celtibérica de Sigüenza o la de Aguilar de Anguita entre otros-, la revisión de antiguas colecciones de materiales - como la de Cerralbo-, y sobre todo, la propia carta arqueológica de Nuria Morère. Fruto de este contexto fue el desarrollo de distintas campañas de prospección, algunas más sistemáticas y programadas y otras de carácter más concreto, dirigidas, por ejemplo, a inventariar los yacimientos existentes en zonas que podían verse afectadas por la construcción de infraestructuras. Por ejemplo, en la primavera de 1991 Cesar María Batalla Carchenilla realizó una prospección arqueológica en la zona de Santamera con motivo de la construcción del embalse del Atance (BATALLA, 1996).

En este contexto debemos destacar los trabajos de Jesús Valiente Malla, quien, sin ocuparse del periodo andalusí directamente, no lo excluyó en las distintas prospecciones realizadas, bien de manera esporádica o bien dentro de programas planificados de prospección que se integran en esta renovada preocupación institucional por los restos arqueológicos a la que aludíamos. Gracias a sus trabajos salieron a la luz nuevos yacimientos no conocidos con anterioridad (recogidos en BALBÍN y VALIENTE, 1995). El primero de todos al que debemos referirnos es a la Cueva Harzal de Olmedillas, en el que debemos detenernos dada su importancia, por ser uno de los únicos yacimientos que han arrojado una cronología andalusí de los que se han excavado en el norte de la provincia de Guadalajara. Aquí se realizaron en 1981 unas prospecciones con sondeos, no publicadas 
hasta 1983 (VALIENTE y GARCÍA-GELABERT, 1983; también referido en MORĖRE, 1983). Se sabía de un posible poblamiento antiguo en ella desde los trabajos del Marqués de Cerralbo a principios de siglo XX (AGUILERA, s.f., pp. 6-8), sospechándose acerca de una posible ocupación prehistórica por algunas cerámicas y útiles de hueso, sílex y piedra (FERNÁNDEZ-GALIANO, 1979: pp. 21-22 y láminas IX-XI). La intervención permitió conocer la existencia de una serie de estructuras en el interior de la cueva, cuya tipología constructiva (muros a espiga y tizón), por semejanzas a otras existentes en Atienza, Peñahora o Trillo (ambas en Guadalajara), en Gormaz (Soria) o en algunos castillos de Alicante, permitieron fijar su cronología como de época altomedieval. El hecho de que los muros tuvieran además un revoco de cal con pintura en almagra, junto con la aparición de cerámicas como jarras con pintura roja o cuerpos de ollas globulares con marcada carena, les lleva a puntualizar aún más que podría tratarse de una fase andalusí (VALIENTE y GARCÍA-GELABERT, 1983: pp. 12-16):

... el edificio de la cueva grande, las construcciones que se alzan en la ladera opuesta y las cerámicas medievales que hemos recogido nos indican una ocupación de este paraje en época califal, posiblemente con intenciones defensivas frente a las tierras del Duero, ya que el Barranco de la Cueva constituye un paso natural entre el Valle del Henares y las tierras sorianas que se extienden más al norte. Se trataría de un ribat de los muchos que defendían el tramo central de la Marca Media... (VALIENTEY GARCÍA-GELABERT, 1983: p. 22)

Además de estas consideraciones, se atrevieron a postular la existencia de otras construcciones califales en la comarca seguntina,

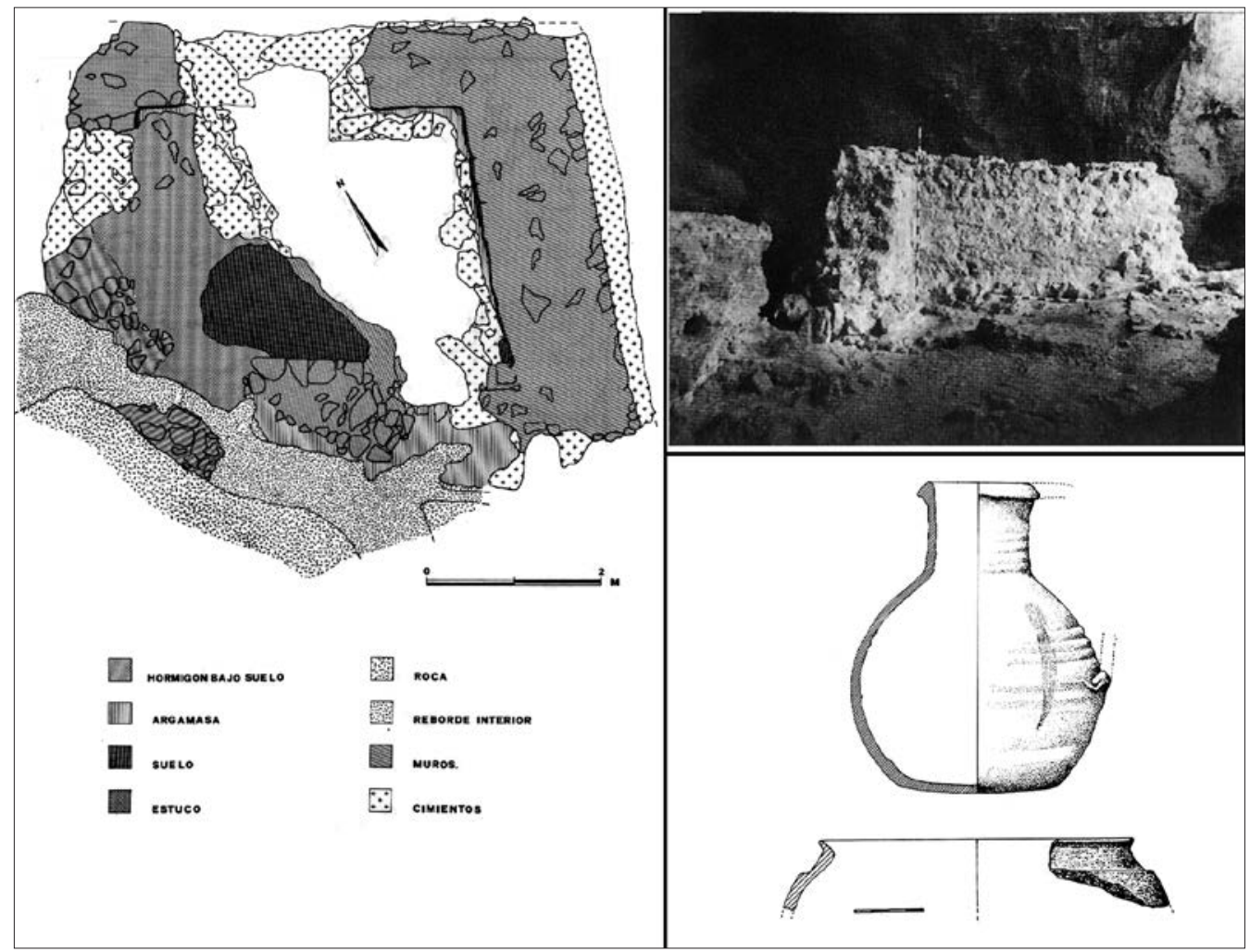

Fig. 3. Restos andalusies identificados en las excavaciones de la Cueva Harzal (Olmedillas) según VALIENTE y GARCÍA-GELABERT, 1983 (Imágenes tomada de la versión digital disponible en el repositorio del Centro de Estudios Históricos de Castilla-La Mancha: http://www.uclm.es/ceclm/b_virtual/revistas/wad_al_haya-

ra/index.htm). Montaje de imágenes del autor. A la izquierda Plano del edificio situado dentro de la llamada "Cueva Grande»; arriba a la derecha Vista del mismo edificio (en B/N en el original, la calidad de la foto se debe a la escasa luz existente en el interior de la cueva). Abajo a la derecha dos de las cerámicas andalusies recuperadas. (Montaje de imágenes del autor) 
como por ejemplo las torres de las iglesias de Alcuneza y Sauca (VALIENTE y GARCÍAGELABERT, 1983: p. 14).

Poco a poco se iban teniendo más elementos de comparación y contraste para datar materiales andalusíes, tanto cerámicos como arquitectónicos, gracias en parte al trabajo de Basilio Pavón al que después nos referiremos. Esto permitió al propio Jesús Valiente ir dando a conocer la existencia de nuevos asentamientos de época islámica localizados en sus numerosas prospecciones o reconocimientos superficiales del terreno. Destaca, por ejemplo, que en Atienza se lograra definir la existencia de una ocupación plenomedieval más compleja que la que siempre se había referido, la del castillo. A partir del hallazgo de una moneda de Abd al-Raḥmān I fechada en torno al 779-780 y de restos cerámicos (VALIENTE y CUADRADO, 1988) ${ }^{41}$, determinaron la existencia de una ocupación de época árabe en el cerro Padrastro, una elevación situada al noroeste del castillo, a espaldas del actual pueblo.

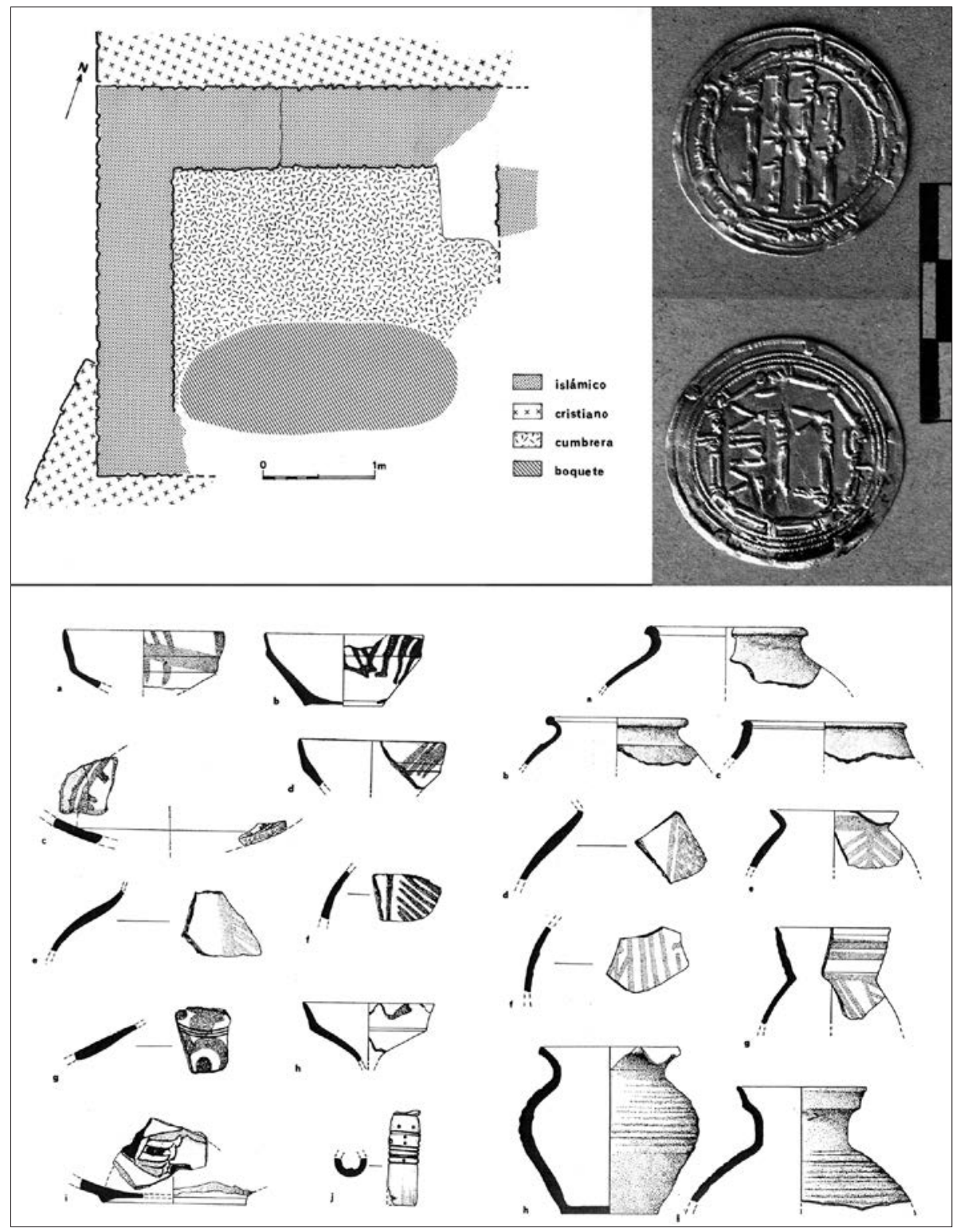

Fig. 4. Restos andalusies identificados en Atienza y el cerro Padrastro, según VALIENTE y CUADRADO, 1988: pp. 634 y 637-638. Arriba a la izquierda planta del coronamiento de la torre norte del castiIlo; arriba a la derecha moneda de 'Abd al-Rahmān I proveniente del Cerro Padrastro; abajo materiales procedentes del castillo de Atienza (Montaje de imágenes del autor, en $B / N$ en el original)

41 En el trabajo que presentan llega a afirmarse que "se ha practicado un desmonte en la ladera oeste del Cerro del Castillo; de las tierras extraídas hemos recuperado algunos fragmentos cerámicos y una pieza ósea.» (VALIENTE y CUADRADO, 1988: 635). No parece que se tratara de una excavación estratigráfica planificada, y el resto de materiales que presentan provienen todos ellos de recogidas superficiales. 
Este, y algunos otros yacimientos de los que a partir de ahora se conoce su ocupación en época andalusí, serán recogidos por el mismo autor en una pequeña Guía arqueológica de Guadalajara publicada a finales de los noventa (VALIENTE, 1997). Entre otros, y aunque se eche en falta una mejor documentación gráfica de los elementos muebles e inmuebles citados, cabe destacar el que diera a conocer las fases andalusíes de yacimientos como el Casuto de los Moros, en Santamera (VALIENTE, 1997: pp. 66).

No obstante, Ilama la atención que a pesar de los nuevos yacimientos que él mismo dio a conocer, cuando se plantea realizar una síntesis general, diga en 1997, aludiendo al periodo andalusí y sus restos arqueológicos que

Guadalajara fue territorio importante en la frontera de la marca Media islámica (el tramo central de la frontera entre moros y cristianos) desde la época en que unos y otros organizan sus territorios en el siglo VIII hasta la reconquista del Reino de Toledo en el siglo XI. No es de extrañar que aparezca hoy salpicada de restos de aquella cultura. Pero su misma condición de tierra fronteriza, alejada de los centros de poder importantes, no propició un desarrollo urbano y monumental comparable al de otras comarcas más meridionales. Fortalezas, infraestructuras viarias y poco más es lo que nos ha llegado de la herencia islámica en forma casi siempre de restos dispersos y mutilados (VALIENTE, 1997: p. 21)

Junto a la carta arqueológica de Nuria Morère y los trabajos de Jesús Valiente, otra obra de referencia inexcusable que supuso un salto cualitativo, y sobre todo cuantitativo, sobre el periodo andalusí en la provincia de Guadalajara, es el trabajo de Basilio Pavón (PAVÓN, 1984). Como el autor escribió en la introducción del libro, la necesidad de realizarlo estribaba en la absoluta carencia de estudios modernos y la imperiosa necesidad que de ellos había, y así desde el C.S.I.C., institución de la que formaba parte, se programó un estudio lo más exhaustivo posible, tanto de Guadalajara, como de otras zonas sobre las que había un limitado conocimiento, caso de Alcalá de Henares (PAVÓN, 1982). Aunque se ha criticado esta obra por presentar ciertas carencias, sobre todo «debido a su característica carencia de orden y metodología científica y arqueológica» (ZOZAYA, 1991: p. 373), no cabe duda de que supuso un auténtico punto y aparte en la investigación del periodo andalusí en la provincia. Quizás su importancia radique en el volumen de datos que recoge y en las interrogantes que plantea, aunque tampoco hay que minusvalorar muchas de sus interpretaciones. Desde las primeras páginas dejó claro que «la Alcarria estaría poblada de pequeñas alquerías, casas de labor diminutas que irán evolucionando hasta erigirse en un poblado o aldea» (PAVÓN, 1984: p. 10), rompiendo la tradicional imagen de un espacio meramente defensivo y prácticamente vacío, aunque por otro lado tampoco niega «el contundente predominio de topónimos militares sobre las voces aldea y alquería» y destacó la labor fundadora de castillos, fortificaciones y torreones de ciertos emires y califas (PAVÓN, 1984: 11). También se mostró a favor del impacto del poblamiento beréber al hablar de la arquitectura o la toponimia, y mostró, con precaución, los posibles enclaves mozárabes de sitios como Aragosa, Alcuneza o Riba de Santiuste, por sus topónimos de raigambre preislámica o mozárabe.

En las páginas dedicadas a la comarca que nos interesa (PAVÓN, 1984: pp. 68-112 y pp. 141-153) da a conocer algunos yacimientos árabes no estudiados con anterioridad, basando las dataciones que ofrece en la recogida de cerámica superficial, que presenta con toscos dibujos a mano y en ocasiones valiosas fotografías a color, o en el estudio de la arquitectura y técnicas constructivas cuando era posible, o presentando inscripciones, epigrafías o estudios de techumbres de iglesias con posibles influencias u orígenes mudéjares. También apuntará en algunos casos indicaciones respecto a la toponimia cuando no hay restos materiales, aunque estos debemos tomarlos con mucha más precaución. En definitiva, el trabajo de Basilio Pavón supuso un paso adelante de indudable valor, aunque 
en ocasiones su mayor interés por los aspectos artísticos haga que se pierda la deseable dinamicidad histórica. De su trabajo ha dicho Ernesto García-Soto que «supuso un verdadero hito en la historiografía provincial no suficientemente valorado y el inicio de un nuevo camino en la investigación histórica que tantas puertas abrirá a la postre» (GARCÍA-SOTO, 2005: p. 7).

Mucho más completo metodológicamente hablando que las publicaciones de Basilio Pavón o las de Jesús Valiente que mencionábamos anteriormente, es el trabajo de Manuel Retuerce. Centró su investigación fundamentalmente en el estudio de las cerámicas islámicas del centro de la Península Ibérica. Recogió la tradición iniciada desde finales de los años setenta (ZOZAYA, 1975; ROSSELLÓ, 1978), publicando sus primeros estudios sobre las cerámicas islámicas de la Marca Media a principios de los ochenta (RETUERCE, 1984), e incluyendo el estudio del primer conjunto de cerámicas islámicas en la provincia de Guadalajara, el de Torote (RETUERCE, 1984b) ${ }^{42}$. En estos trabajos lo que va a primar, además de una correcta descripción y caracterización de las formas y decoraciones, va a ser la preocupación territorial, tratando de descifrar posibles distribuciones geográficas detrás de las cuales podrían encontrarse grupos sociales (étnicos o tribales) distintos (RETUERCE y ZOZAYA, 1986). Estos trabajos van a formar parte de la tesis doctoral elaborada durante los años ochenta y principios de los noventa y que, tras publicar algún adelanto (RETUERCE, 1994 y 1995), vio la luz finalmente del siglo XX (RETUERCE, 1998). Además del enorme corpus de yacimientos que recoge (aunque la mayor parte de los conjuntos cerámicos no provengan de excavaciones con estratigrafías solventes), sus trabajos tienen la virtud de intentar poner en relación la cultura material y el estudio de la topología o la decoración, con la sociedad y el territorio en el que se generaron. Para la zona del Alto Henares, Manuel Retuerce recogió nuevos asentamientos, o mejor dicho cerámicas islámicas provenientes de yacimientos que no aparecían en la carta arqueológica de la región realizada por Nuria Morère (bien por desconocimiento o bien porque quedaban fuera de los límites de la zona estudiada), como son los de Miedes de Atienza, el cerro Padrastro en Atienza, el castillejo en Tordelrábano, La Espina en Santamera, Huérmeces, Aragosa, Mandayona, Torresaviñán, Castejón de Henares, Bujalaro, Cendeja de la Torre, o Iñesque (en Angón) (RETUERCE, 1998: t ll p. 15 y pp. 18-19) alguno de los cuales ya se conocían desde unos años antes, pero sólo como puntos distribuidos en un mapa (BALBíN y VALIENTE, 1995) (Fig. 5).

Desde entonces, este trabajo, junto con el de Basilio Pavón y el de Nuria Morère, se van a convertir en referente indiscutible de cualquier estudio que se realizara sobre el poblamiento andalusí en Guadalajara, sobre todo en los estudios del valle del Henares (BERMEJO y MUÑOZ, 1996 y 1999), pero también en la Sierra Norte, ya que durante años no ha habido más investigaciones de carácter arqueológico para los siglos centrales de la Edad Media. Una excepción podrían ser los trabajos de Jorge Jiménez, uno de ellos realizado sobre el yacimiento de Peñahora localizado cerca de Humanes (JIMÉNEZ, 1989) dando a conocer su localización y arquitecturas visibles en superficie como murallas y torres; y una guía de castillos y torreones de la provincia (JIMÉNEZ, 1992-1993). En ambos trabajos se apunta la cronología islámica de muchas de estas construcciones, aunque no siempre con la misma cantidad y calidad de argumentos. No obstante, más que arqueológicos, se tratan de unos estudios próximos a la historia del arte o de la arquitectura histórica, así como la poliorcética. Estas construcciones no suelen presentarse en un estudio de poblamiento más complejo, más allá de la referencia a la frontera, sino que cada una es tratada individualmente.

Como vemos, el estudio de los restos materiales que podían adscribirse a época

42 Torete es una pequeña aldea situada a 20 kilómetros al oeste de Molina de Aragón, aproximadamente a 100 km al sureste respecto a Sigüenza. 


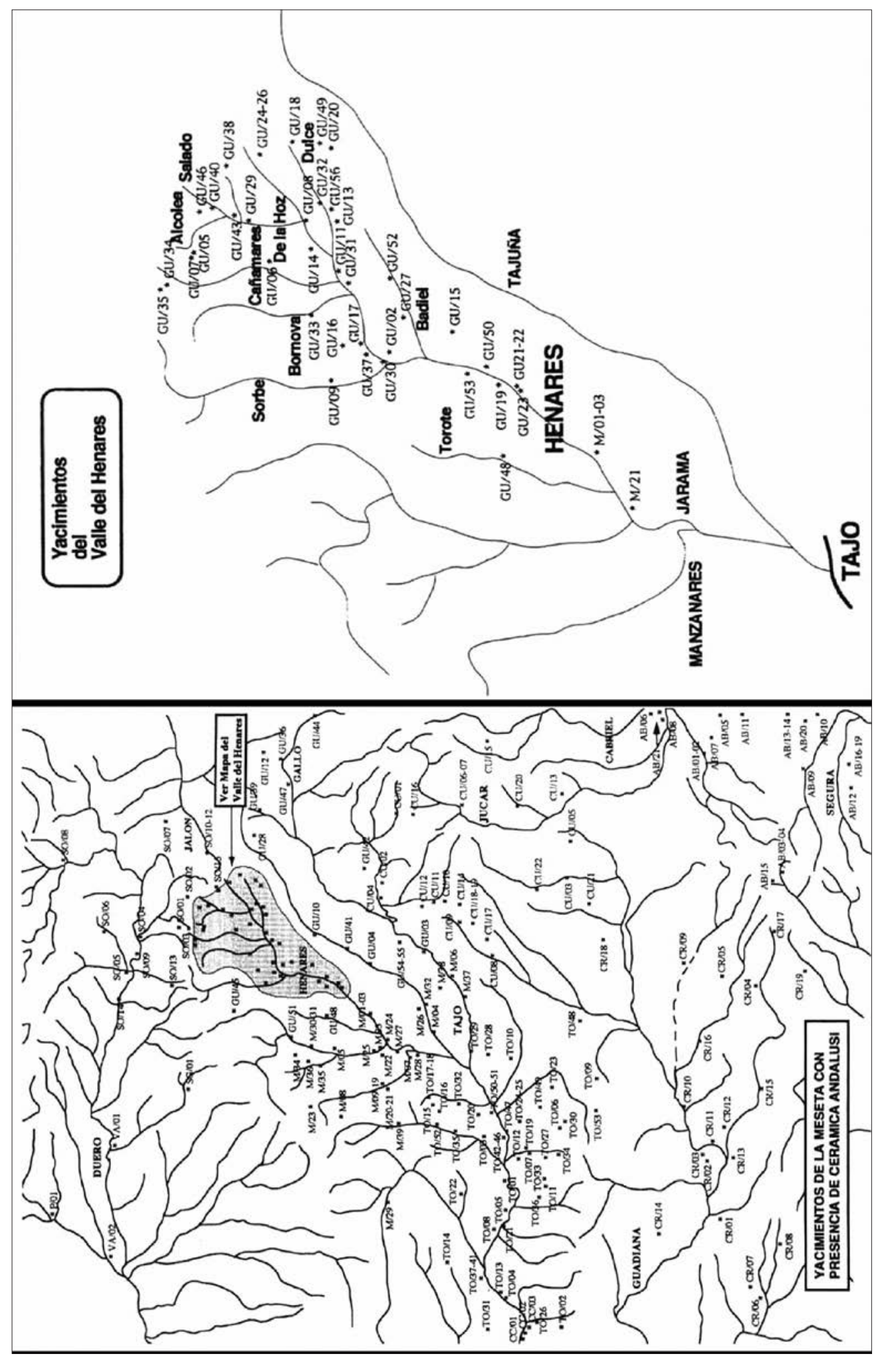

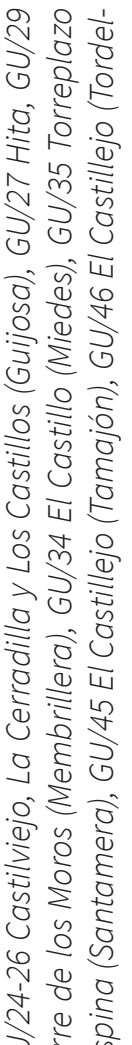

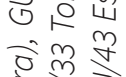

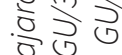
$\begin{array}{lll}0 & 0 \\ 0 & 0 \\ 0 & 0 \\ 0\end{array}$

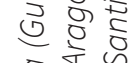
용

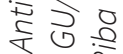
$\frac{10}{0} \frac{1}{2}$

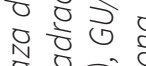

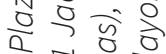
入 पु जे

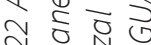

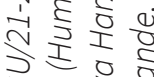
0.90
0
0 टे $\frac{1}{0}$ ज़

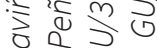
ज० के

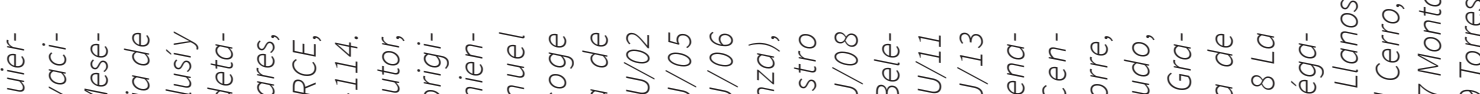

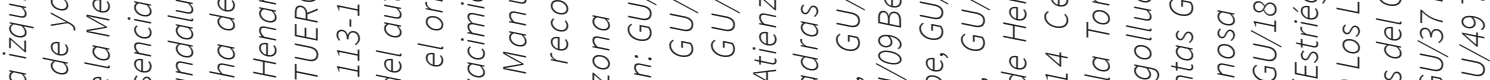

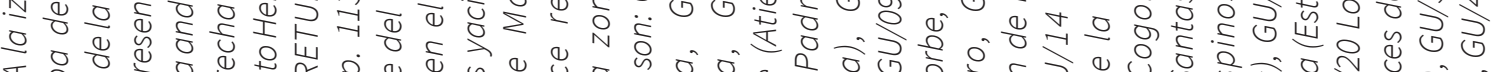

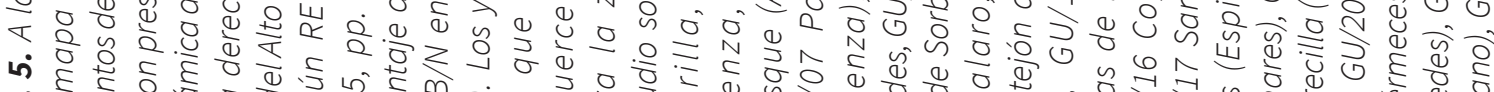

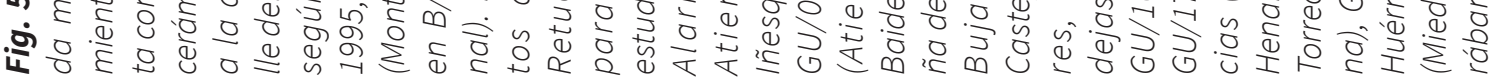


andalusí, fuesen arquitecturas o cerámicas, supusieron un enorme avance. Aún así, aún valorando positivamente estos años, conviene también remarcar que esta investigación fue de menor entidad respecto a la que se estaba produciendo en otras zonas del país en estos mismos años. Por ejemplo, en todos estos trabajos no aparecía ni quedaba reflejada la creciente influencia que la obra de Pierre Guichard, publicada diez años antes, estaba teniendo sobre gran parte de los investigadores de al-Andalus, lo cual no deja de ser paradójico, ya que dicha obra tenía una clara relación con la zona en cuestión sobre todo por la enorme presencia de contingentes beréberes (GUICHARD, 1976).

Distinta es la situación del relato histórico construido desde la documentación escrita en estos mismos años de finales del siglo $X X$. En este sentido, el gran referente para el estudio de al-Andalus en el centro peninsular va a ser la tesis doctoral de Eduardo Manzano (MANZANO, 1991). Centrada en el estudio de la frontera, o mejor dicho de las marcas en tanto que zonas limítrofes amplias y no lineales (MANZANO, 1991: pp. 32 y 69), trata de desentrañar tanto el significado semántico y geográfico que tal consideración debió tener para los omeyas, como estudiar a la población que aquí vivió. Lo hace planteando siempre una doble lectura, por un lado los habitantes locales a los que se le asigna un comportamiento levantisco y de tendencia siempre opositora al poder central, y por otro los omeyas y los gobernadores al servicio de Córdoba en su intento por controlar este espacio, fortalecerlo y evitar el avance cristiano. Dentro del primer grupo incluye y destaca el papel de los beréberes en las distintas zonas de la frontera, en concreto de los Banū Salīm para el tramo que nos interesa, en lo que para él es una «frontera de lealtad imprecisa» (MANZANO, 1991: p. 189). Aunque no sea el primero en señalar la presencia de este grupo de beréberes, hay que reconocer que había sido un aspecto sobre el que apenas se había profundizado, y a él corresponde además el mérito de ser el primero en destacar su importante papel como gobernadores al servicio de Córdoba, y en señalar que las escasas referencias que encontramos en las fuentes escritas sobre ellos quizás se deba a que a partir del siglo $X$ son desplazados como gobernadores debido al interés que tienen los ahora califas en controlar más directamente un espacio que comenzaba a ser frontera directa.

Dentro de su tercer capítulo, dedicado a las Marcas Media e Inferior, dedica un apartado al tramo entre Medinaceli y Guadalajara, que es el que más nos interesa (MANZANO, 1991: pp. 150-163). En él, sin embargo, no recoge todos los yacimientos que para la fecha en la que se publica el libro ya se conocían por prospecciones arqueológicas (vid. supra), fijándose el poblamiento sólo por aquellos que aparecen citados en los escritos, provengan éstos de ámbito árabe o cristiano. Aunque el número de sitios no sea tan elevado como cabía esperar, pues no están todos los que ya se conocían, sí hay que reconocer que es a partir de ahora cuando el poblamiento va a ir dotándose de un modelo explicativo más o menos coherente, aunque no exento de críticas al respecto, bien por el escaso peso otorgado a la organización tribal (GUICHARD, 1997) o bien por la no inclusión de los datos arqueológicos en materia interpretativa (SENAC, 1993). De acuerdo con las propuestas de Eduardo Manzano, la frontera, sobre todo la Marca Media, hay que entenderla en un doble sentido, no sólo frente al enemigo leonés o castellano, sino también frente a las revueltas interiores, procedentes en su mayoría de la levantisca ciudad de Toledo, pero también de otras zonas como Santaver, por lo que habla de una «frontera interior» (MANZANO, 1991: p. 274) reconociendo que los Omeyas no llegaron a cristalizar nunca un gobierno centralizado (MANZANO, 1991: pp. 387-388).

El mayor mérito de esta obra quizás sea, dejando a un lado su labor de síntesis histórica y de visión de conjunto, el haber señalado que las fuentes escritas ofrecen una imagen distorsionada del proceso histórico de aquellos territorios más distantes del poder central cordobés. Además, proporciona dinamicidad a cuatro siglos de historia que hasta ahora se habían narrado de una forma estática, mostrando cambios en las fidelidades e inte- 
reses entre poder central y poderes locales, que podrían estar detrás también de algunas dinámicas del poblamiento. Prueba de ello sería la fundación de algunos asentamientos, como el de Peñahora (cerca de Humanes), o la pérdida de importancia en época emiral para volver a resurgir después en época califal del sitio de Medinaceli. Algunas de las ideas que se apuntaron en esta obra tuvieron un gran impacto, como la reorganización de la frontera en tiempos de 'Abd al-Rahmān III (MANZANO, 1991: p. 152), que a nivel arqueológico podría interpretarse por la reaparición de nuevas fortificaciones o la reparación de las ya existentes.

Pero, si por algo destacan las páginas que se dedican al territorio que nos interesa, es que vuelve a insistirse en el hecho de que todo se explica por el hecho fronterizo, y la imagen vuelva a ser la de una zona poblada de castillos, atalayas, ciudades amuralladas, y una vía de comunicación de época romana, ahora reutilizada. Es la imagen de un territorio en el que parece no haber más vida que aquella consagrada a la guerra, la defensa o los juegos de poder, rebeliones, traiciones y alianzas, sin que, al final, quede claro qué o a quiénes están defendiendo o atacando.

Llegados a este punto, debemos hacer una reflexión genérica de la idea que a finales del siglo XX se tenía sobre el poblamiento y el territorio andalusí de la Marca Media, y especialmente de su sector oriental (es decir, el norte de Guadalajara), antes de pasar a ver qué ha ocurrido en los últimos años. Adelantaremos ya que son los años ochenta y noventa los que supusieron el mayor paso adelante para el conocimiento del poblamiento andalusí en este sector oriental de la Marca Media. Y ello se debió fundamentalmente al aporte de la arqueología, beneficiada en gran medida por la promulgación de las Leyes de Patrimonio Histórico Español de 1985 y de Patrimonio Histórico de Castilla-La Mancha de 1994. Sin esta institucionalización de la arqueología no se entendería la preocupación consiguiente por la protección, conservación y difusión, y en menor medida por la creación de nuevo conocimiento, de los restos arqueológicos.
Junto al papel de las distintas universidades, sobre todo de las madrileñas, es importante el papel del museo arqueológico de Guadalajara, y más aún cuando desde 1983 la Junta de Comunidades de Castilla-La Mancha asumió las competencias en materia de arqueología y un año después convocó un Congreso de Historia que supuso un momento de eclosión de la investigación, especialmente en materia arqueológica (SANZ, 2010: pp. 31-36).

En este contexto, y con los trabajos antes mencionados, había quedado claro que la documentación escrita no reflejaba todos los lugares que la arqueología iba poco a poco desvelando (PAVÓN, 1984: p. 17). Aunque en su explicación seguía primando el elemento defensivo, poco a poco se iban integrando otros argumentos, y se iba haciendo cada vez más compleja la narrativa histórica sobre el periodo. Así lo veía, a principios de los noventa, Juan Zozaya:

... la zona de la Frontera Media se presenta con una gran densidad de población si atendemos a los datos que proporciona la arqueología. Se puede decir que a un promedio de cada 60-80 kms de distancia había una ciudad importante (Madrid, Guadalajara, Medinaceli \&c) con poblaciones intermedias y con las postas correspondientes. Estas poblaciones, cualesquiera que fuera su categoría, se asentaban en los valles, cerca de los cursos fluviales, que a su vez constituían las vías de comunicación, enmarcándose dentro de un sistema defensivo (...) Lo anteriormente expuesto da una imagen bastante clara de un mundo urbano bastante desarrollado y de un mundo rural de un nivel muy alto, casi podemos decir que "urbanizado", menos contrapuesto al de la ciudad, a juzgar por los hallazgos de piezas bastante elaboradas técnica y conceptualmente. (ZOZAYA, 1991: p. 380)

Y más adelante especifica que:

El poblamiento puede establecerse como un sistema estructurado de manera racional, con pautas de distancias entre asenta- 
mientos, que se jerarquizan, y que puede fecharse en torno al siglo X, como sistema no sólo de explotación económica del territorio, sino de defensa mediante la ocupación del mismo. (ZOZAYA, 1991: p. 381)

No obstante, a pesar de que se había producido un gran salto adelante en el conocimiento del sector noreste de la provincia de Guadalajara durante la época andalusí, este territorio seguía quedando fuera de las reflexiones generales que se hacían sobre el poblamiento en la Edad Media en esos siglos centrales de la Edad Media (por ejemplo PORTELA, 1985; LALIENA y UTRILLA, 1998; MARTÍNEZ y SERRANO-PIEDECASAS, 1998), salvo a partir del momento en el que es conquistado por los castellanos. Y junto a ello, la escasa incidencia que tuvo en los estudios sobre la provincia la renovación sobre al-Andalus que supuso la interpretación social de Guichard (GUICHARD, 1976). Muestra de ello lo constituyen los artículos recogidos en la revista Wad-al-Hayara, principal revista de historia y arqueología de la provincia de Guadalajara, Aunque desde su nacimiento en 1974 y hasta nuestros días «ha sido uno de los canales por los que la historiografía alcarreña ha discurrido hasta su total engarzamiento con los fundamentos y supuestos en los que se basa la actual ciencia histórica» (BALLESTEROS, 1991: pp. 67-68), en el caso concreto del estudio de al-Andalus muestra las mismas carencias que venimos señalando. Lo mismo ocurre si examinamos los que pueden ser considerados los principales hitos de la renovación historiográfica de Guadalajara, como los dos primeros encuentros de historiadores de la provincia de Guadalajara, o el I Simposio de Medievalismo Alcarreño, cuyas comunicaciones fueron presentadas en el número 12 de la ya citada revista Wad-al-Hayara.

Las únicas excepciones que podemos hacer son aquellas referencias que se realizan a las fortificaciones de Atienza o Riba de Santiuste, a los torreones o la toponimia de Bujalaro, Barbatona o Bujalcayado, o cuando se hacía referencia a la importancia de las vías de comunicación de origen romano, reutilizadas en época andalusí. Y ello a pesar del notable avance que suponía la catalogación de casi una veintena de nuevos yacimientos de posible adscripción andalusí. Además, existía un contexto historiográfico sobre al-Andalus en el que cada vez había más estudios tanto desde las fuentes escritas como sobre todo desde la arqueología, que incluso plantean interesantes cuestiones sobre el poblamiento rural en otras partes del valle del Henares (BERMEJO y MUÑOZ, 1994, 1995-1996, 1996, 1999). Pero el debate sobre el poblamiento andalusí en la comarca seguntina no trascendía prácticamente del ámbito local o provincial. Y cuando lo hace, es para integrarse en una narrativa histórica en la que todo se explica por el mismo hecho fronterizo, por las necesidades de defensa o el control de vías de comunicación para el ataque, o por la presencia de población beréber, ya que es también en este periodo cuando aparecen algunos trabajos que insisten en la presencia y el dominio de los Banū Salīm en este territorio (como el ya citado MANZANO, 1991). Después, distintos trabajos centrados en el papel de los beréberes en al-Andalus, y especialmente en las zonas de frontera, vuelven a ponerlo de relieve, aportando en algunos casos nuevos datos o revisando y criticando ideas anteriores (JIMÉNEZ 1995: p. 211; FELIPE, 1997: pp. 122-124, 220-224, 309-310 y 348-349) Estas ideas no son exclusivas para el norte de Guadalajara, sino que en gran medida son la tónica dominante que hay sobre el poblamiento en toda la Marca Media hasta finales de los años noventa (recogidas en su mayoría en SÁEZ, MALALANA y MARTÍNEZ, 1999).

Más adelante tendremos ocasión de ver en qué medida esta reducción de la interpretación del poblamiento al hecho fronterizo ha podido variar en los últimos quince años.

Otra idea historiográfica surgida con fuerza en estas tres décadas de los setenta a los noventa, y que prácticamente se ha mantenido vigente hasta hoy en día, es la de que sigüenza era un núcleo importante en época andalusí, destacando el papel de su castillo y de una iglesia en la parte llana junto al río, de origen visigodo que se mantuvo hasta la plena Edad Media. Ello daría pie a hablar de una comunidad mozárabe que habitó Sigüenza 
e incluso los alrededores, basándose en el topónimo de Alcuneza, que podría provenir del árabe y significaría «iglesia». Y todo ello a pesar de que no hay ni restos arqueológicos ni menciones en las fuentes escritas después del siglo IX. Así lo explicaba Adrián Blázquez, en un texto en el que pensamos se resumen en gran medida las ideas que se tenían y que se habían fijado:

Si el nombre de Sigüenza no aparece, pues, sino muy raramente en estos documentos es, sin duda, debido a su situación fronteriza, palestra de refriegas, incursiones y devastaciones que habian dejado a la ciudad en un estado semi-desértico por esta época. En realidad, por estos años, Sigüenza no era sino una pequeña aldea, casi despoblada, dependiente de Medinaceli. (BLÁZQUEZ, 1985: p. 37 y 1988: pp. 43-44)

E incluso, sin que conozcamos ningún resto material para Sigüenza, se afirma que

En realidad Sigüenza no representaba una fortaleza poderosa, reducida como estaba por aquellas fechas a un castillo mejor o peor defendido y algunas docenas de familias mozárabes, que más bien ayudarían al obispo a conquistar el castillo que se opondrían a él (BLÁZQUEZ, 1988: p. 48)

También Pilar Martínez sustentaba las mismas ideas con argumentos similares:

En este sistema destaca por su importancia Guadalajara, ciudad de creación árabe surgida, como en el caso de Alcalá, en un emplazamiento estratégicamente bien dispuesto para su misión defensiva (...) Más al este se alzaban núcleos de menor entidad en torno a fuertes castillos, situados en los lugares más estratégicos, fundamentalmente en los pasos de la Sierra, por ejemplo Atienza (...) Sigüenza, por su parte, que se había visto convertida en simple aldea de Medinaceli, sobre todo a raíz de la transformación de esta antigua ciudad romana en un fuerte enclave árabe cabeza de la «marca media», formaba, sin embargo, parte de este sistema con su alcazaba erigida en esta época. (MARTí-

NEZ TABOADA, 1985a: p. 58)

Es una cuestión sobre la que directamente no hay debate (al menos hasta fechas muy recientes: GARCÍA-CONTRERAS, 2014). Se ha aceptado, a pesar, por ejemplo, de las precauciones que en la Carta Arqueológica Seguntina se ponían sobre los restos arqueológicos del casco urbano. Sin esgrimirse como argumento ni un solo resto arqueológico ni una referencia documental, esta idea sobre Sigüenza tuvo su impacto, sobre todo, en los trabajos más amplios que trataron de realizar una síntesis general sobre el poblamiento en la Marca Media. Fiándose de manera acrítica de esta historiografía local, incluyeron Sigüenza en la nómina de fortificaciones de la frontera media, o incluso en ocasiones, como si hubiera sido una ciudad, con lo que los esquemas de poblamiento se apoyan en esta idea, con muy pocas excepciones que pongan en duda su existencia o al menos lo traten con cautela (SÁEZ, MALALANA y MARTÍNEZ, 1999).

Pero el principal problema que tiene la historiografía que heredamos del siglo XX es, a nuestro juicio, la incapacidad mostrada por insertar y contextualizar adecuadamente las nuevas listas de yacimientos conocidos dentro de discursos complejos que atiendan a planteamientos sociales y económicos que huyan de una historia excesivamente política y militar.

\section{Los últimos quince años de historiografía sobre al-Andalus}

Si comparamos las reflexiones en torno a la Arqueología Medieval hechas por Miquel Barceló en 1988 y las expuestas por Ricardo Izquierdo en 2005 es evidente el cambio. Mientras que el primero afirmaba que «el retraso de la arqueología medieval española respecto a la de otros países europeos es sencillamente colosal» (BARCELÓ, 1988: p. 10), el segundo, en un tono más positivo y voluntarista escribía que «lo que verdaderamente destaca es el indudable desarrollo que ha alcanzado en los últimos años, habiendo comenzado a ocupar el lugar que le correspondía» (IZQUIERDO, 2005a: 
p. 225. Del mismo autor 2005b y más recientemente 2011). Este desarrollo de la Arqueología Medieval desde los años 80 en nuestro país ha llegado a ser calificada como de «revolución silenciosa» por su gran calado, generando en los últimos años una explosión de debates y propuestas que en muchas ocasiones trasvasan el marco cronológico «clásico» atribuido a la Arqueología Medieval y entrar en el terreno de la teoría arqueológica general (QUIRÓS y BENGOETXEA, 2006: pp. 52-67).

En los últimas décadas ha habido un salto cuantitativo en las excavaciones arqueológicas de la provincia, pero no siempre se ha traducido en un salto cualitativo en el conocimiento que tenemos sobre los distintos periodos históricos, especialmente sobre el andalusí. Esto se debe, en parte al fuerte desajuste territorial, plasmado, por ejemplo, en la práctica inexistencia de cartas arqueológicas de carácter local o comarcal (BALBín y VALIENTE, 1995) ${ }^{43}$. Dejando a un lado la ya citada de Nuria Morère (1983), sólo tenemos constancia de la redacción de la Atienza (citada en IGLESIAS, 1992), la de Palazuelos (VELA y RIVERA, 2002), y en un estudio realizado recientemente sobre el tema sólo aparece como «Entregada sin resolución», una, la correspondiente a Sienes (ORTIZ, PANTOJA y SÁNCHEZ, 2010: p. 1120) ${ }^{44}$. También sabemos que está en fase de redacción y finalización una más reciente sobre Sigüenza y sus pedanías y aldeas dependientes, pero no ha sido aún publicada ${ }^{45}$.

La falta de estas cartas arqueológicas no quiere decir que no se esté investigando. Se trata más bien de un problema administrativo, de protección y conservación y de visibilización de los estudios, pero no tanto de inves- tigación per se, aunque indudablemente estos se ven absolutamente condicionados. Como se señala en el primer intento por elaborar una Carta arqueológica de Guadalajara:

... se pretendía, como en otras provincias de la Autonomía, obtener una base adecuada para saber cuales eran los restos arqueológicos de importancia en su territorio, y cuales habian de ser declarados BIC y protegidos especialmente bajo el punto de vista administrativo y gubernamental. Esta premisa, que podría aparecer como obvia, no lo es, y debe ser propuesta desde el comienzo, pues indica cuál ha sido el motivo de la realización de esta actividad, que no es exactamente el científico aunque éste sea necesario para un correcto desarrollo, sino el administrativogubernamental, con conclusiones más útiles para el funcionamiento práctico que para la actividad investigativo-científica. (BALBÍN y VALIENTE, 1995: p. 11)

Es decir, aunque administrativamente sí que existe un cierto interés en recoger los yacimientos conocidos, detrás de ello hay una cierta falta de investigación básica, y muy especialmente para los restos andalusíes. No obstante, es en estos últimos años cuando se continúa con ese salto cualitativo y cuantitativo en el conocimiento del período medieval de la región que ya había comenzado décadas antes de la mano de la arqueología. Se puede ver, fundamentalmente, en distintas publicaciones que recogen los trabajos de arqueología de Guadalajara (GARCÍA-SOTO y GARCÍA, 2002; GARCÍA-SOTO, GARCÍA y MARTÍNEZ, 2008), los simposios de historiadores del valle del Henares ${ }^{46}$, o con un carácter más

43 Desde el año 2010 se está llevando a cabo la redacción de las cartas arqueológicas de los 85 municipios que integran la Asociación para el Desarrollo Local de la Sierra Norte (ADEL-Sierra Norte) (ANÓNIMO, 2012)

44 Es notoria, además, la desigualdad general que existe entre las cartas arqueológicas del resto de provincias de la Comunidad Autónoma y Guadalajara, y dentro de ésta, especialmente la desigualdad entre el norte y otras regiones, como Molina de Aragón.

45 La nueva Carta Arqueológica de Sigüenza ha sido realizada por la empresa Arquequipo, bajo la dirección de Enrique Gamo Pazos. Esperamos sea publicada lo antes posible. En la propia web de la empresa, y en su perfil en la red social twitter, se anunció en junio de 2012 que el documento había sido ya terminado, aunque por el momento no nos ha sido posible consultarla: http:// www.arquequipo.com y https://twitter.com/arquequipo (Última visita a ambas web en octubre de 2013)

46 Se trata de unas reuniones que se celebran alternativamente en Guadalajara y en Alcalá de Henares, auspiciadas por una asociación homónima. El primer encuentro se celebró en Guadalajara en 1988, y en noviembre de 2015 se celebra la decimoquinta edición. 
amplio para toda la investigación arqueológica de Castilla-La Mancha (W.AA., 2004; MILLÁN y RODRÍGUEZ, 2007; BELINCHÓN y PERLINES, 2010). Y sobre todo, en el hecho de que ya ha sido posible esbozar las primeras visiones historiográficas sobre la arqueología medieval de la provincia de Guadalajara (CUADRADO, 2002; OLMO, 2002).

Aunque sea difícil tomar perspectiva de una época tan reciente, vamos a tratar de describir por donde ha discurrido la historiografía en estos últimos años, intentando, como hasta ahora, centrarnos fundamentalmente en el sector noreste de la provincia.

Lo primero que llama la atención es que en distintas publicaciones se insista y reitere constantemente la necesidad que hay por conocer el periodo andalusí en el sector oriental del Sistema Central o en la comarca de Sigüenza obviando en ocasiones los propios trabajos que ya se habían llevado a cabo, o ignorando muchas de las propuestas que se han vertido. No pensamos que sea intencional, pero no se entiende por qué en algunas obras de síntesis se obvian ciertas cuestiones o no se citan determinados trabajos que podrían haber ayudado a cimentar las investigaciones posteriores. Es lo que ocurre con un trabajo de Fernández Ugalde, publicado a principios de siglo (FERNÁNDEZ, 2001). Este trabajo, quizás por su título o quizás por el lugar en el que fue publicado, ha pasado desapercibido para la mayoría de los investigadores que en estos últimos años han trabajado o publicado sobre el periodo andalusí en el norte de Guadalajara, como Lauro Olmo, Enrique Daza, Ernesto García Soto, Pedro Olea o Ricardo Barbas Nieto, de los que hablaremos más adelante. Más que presentar datos o conclusiones, este artículo lo que plantea es una serie de cuestiones referidas a la posibilidad de identificar el poblamiento beréber en la Marca Media. Pero, sobre todo, y es lo que consideramos más importante, llama la atención sobre las enormes posibilidades que se abrirían si se aplicaran en la región el Alto Henares y de su afluente, el río Dulce, programas de investigación con metodologías próximas a la arqueología del paisaje, o más concretamente a la arqueología hidráulica, como se había ya planteado para otras zonas de al-Andalus (BARCELÓ, KIRCHNER y NAVARRO, 1996). No plantea resultados, sino lo que él denomina un enunciado de posibilidades de futuro centrado en la llamada arqueología del paisaje y aplicado al alto valle del Henares. Apuntó algunas ideas que nos parecen especialmente sugerentes y dignas de mencionar, sobre todo, aquellas en las que hace converger la toponimia y una lectura muy superficial del paisaje, pero suficiente para darse cuenta de algunas cuestiones de gran calado

Valoramos muy positivamente este trabajo en tanto que es de los primeros en romper con visión generalizada de un poblamiento (el del valle del Henares) analizado en clave «fronteriza» o «militarizada». Planteando, además, la necesidad de estudiar los espacios productivos.

Muestra del escaso impacto de este trabajo lo tenemos en el informe sobre el estado de la cuestión de la arqueología medieval en Guadalajara que presentó Lauro Olmo (OLMO, 2002), donde ni siquiera aparece citado ${ }^{47}$. No obstante, el trabajo de Lauro Olmo es enormemente meritorio, ya que no sólo recopila y sintetiza la mayor parte del conocimiento histórico y arqueológico sobre la Edad Media en la provincia, sino que además trata de exponer los datos de manera interpretativa, barajando hipótesis, proponiendo marcos cronológicos, planteando continuidades y discontinuidades y, sobre todo, reuniendo casi toda la información disponible pero yendo mucho más allá de su simple presentación de manera ordenada. Huye así del estatismo y la falta de dinamicidad con la que se presenta el poblamiento en otras publicaciones anteriores e incluso posteriores. En las páginas dedicadas al periodo andalusí (OLMO, 2002: pp.

47 Quizás porque el coloquio en cuyas actas se publicó se celebró un año antes, en 2000, aunque se vieran la luz en 2002. 
473-482) se muestra la desigualdad regional debida al mayor volumen de investigaciones en áreas del centro y suroeste de Guadalajara, tanto en los principales núcleos urbanos, como sobre todo en Recópolis, yacimiento del que él es el director de las intervenciones arqueológicas (OLMO, 1983, 1988, 1988b, 2000, 2008). Además, trata de poner en relación los resultados de las (pocas) excavaciones efectuadas en la provincia con otros yacimientos de los que sólo se tiene información procedente de prospecciones, reconocimientos superficiales, toponimia o referencias en la documentación escrita, lo que le permite hacer interesantes propuestas acerca de la evolución de los asentamientos. Otro valor añadido en este trabajo es el esfuerzo que hace por incluir aspectos referentes a las actividades productivas, a pesar de la escasez de investigaciones específicas. Llama la atención sobre posibles actividades de extracción y transformación de mineral de hierro, así como la localización de una serie de yacimientos califales en zonas destinadas a la producción de sal. Pero, nuevamente, se muestra la fuerte desigualdad regional que existe en el conocimiento histórico de la provincia, ya que al hablar de estas actividades, hace referencia única y exclusivamente a zonas del señorío de Molina (OLMO, 2002: p. 482), no mencionando siquiera el entorno de las salinas de Imón o La Olmeda, significativamente más importantes, que habían sido abordados ya en relación a la época romana (MORĖRE, 1991) y que serán objeto de estudio en relación con el medioevo en trabajos posteriores (MORÈRE, 2008a, MALPICA Y GARCÍA-CONTRERAS, 2010; GARCÍACONTRERAS, 2009, 2012a, 2013a, 2013b).

También fijará su atención en estos espacios productivos Ana Echevarría, en un trabajo más amplio sobre la explotación de la sal en época altomedieval en el centro peninsular (ECHEVARRÍA, 2009). En su caso, el camino de la investigación no parte del análisis del poblamiento en este sector y su relación con la explotación de los recursos naturales, sino más bien al contrario. La autora, interesada en la explotación de la sal en época andalusí y en general en la alta y plena Edad Media (ECHEVARRÍA, 2005 y 2010), realiza un recorrido por los principales centros salineros del centro de la península, tratando de ponerlos en relación con los esquemas de poblamiento conocidos $^{48}$. Para el norte y noreste de Guadalajara, basándose en estudios anteriores y sin haber realizado trabajo directo de campo, plantea algunas sugerentes ideas sobre un posible control estatal de estos centros productivos por la existencia de algunos castillos asociados como Riba de Santiuste, o por el paso de vías de comunicación importantes, hablando literalmente de «un modo de organización con una superestructura política al frente» (ECHEVARRÍA, 2009: p. 190). No obstante, algunas cuestiones que plantea Ana Echevarría convendrían ser revisadas, como el tema de las torres cuadradas, consideradas únicamente puestos militares, o cuando considera que Sigüenza, una antigua «civitas» romana después convertida en «metrópolis» en época andalusí, era el núcleo desde el que se controlaría el territorio (críticas al respecto en GARCÍA-CONTRERAS, 2014). No obstante, sigue siendo loable el esfuerzo que hace por tratar de relacionar el poblamiento con la explotación de la sal.

A las reclamaciones de Fernández Ugalde por una arqueología del paisaje, las advertencias de Lauro Olmo sobre los espacios productivos, o el trabajo de Ana Echevarría sobre las salinas, hay que unir las investigaciones realizadas desde lo que podríamos denominar como arqueología del territorio o un análisis del poblamiento. Metodológicamente, suponen una mayor implicación de los estudios arqueológicos aún cuando estos sólo conlleven prospecciones y estudios de materiales recogidos en superficie. Interpretativamente, aunque el hecho fronterizo, instaurado desde los años ochenta en la historiografía como veíamos páginas atrás, sigue siendo muy fuerte, comienzan a detectarse cambios en

48 Además de los que nos interesan, aborda en su estudio los conjuntos salineros de Molina de Aragón (también en Guadalajara), de Poza de la Sal en Burgos y de Villafáfila en Zamora. 
su análisis. Esto se pone en evidencia en los temas preferentes de los que se han ocupado los investigadores de la provincia: castillos y torres, fundamentalmente, como había venido haciéndose desde tiempo atrás, si bien incluyendo en su estudio nuevas metodologías o ampliando el interés hacia otras cuestiones como el hábitat rupestre.

Es por ejemplo la línea de trabajo que está llevando a cabo Enrique Daza Pardo desde hace ya diez años, en la que combina el análisis toponímico con el estudio de la arquitectura y una práctica arqueológica que podemos denominar como "arqueología sin excavación»o «arqueología del territorio». Para el territorio que nos ocupa, como objeto de estudio tiene, fundamentalmente, los castillos y las estructuras rupestres o semirupestres. Entre los primeros destacan los de Jadraque (DAZA, 2001 y 2003) y el de Cogolludo (DAZA; LÓPEZ-MUÑIZ y VELA, 2013), y entre los segundos el de Morenglos en Alcolea de las Peñas o la cueva de los Corrales o de la Merendilla, en Tordelrábano (DAZA, 2005-2006, 2007c, 2013). A ello hay que añadir una revisión sobre las necrópolis visigodas (DAZA y CATALÁN, 2009). A partir del estudio más intensivo de estos y algunos otros yacimientos, trabajando solo o junto a equipos de investigación más amplios, ha tratado de plantear reflexiones más generales sobre el poblamiento en algunas partes de la provincia, como el valle del Torote (SALGADO, DAZA y VEGA, 2008), y sobre todo en la Sierra Norte de Guadalajara (DAZA, 2007a, 2007b) ${ }^{49}$. En las propuestas de Daza se apuesta por el mantenimiento de un amplio colectivo de población mozárabe en las zonas de la sierra, lo que explicaría, a su juicio, la propia arquitectura rupestre, asociada al monacato:

La pervivencia tras la "repoblación" de asentamientos de clara raigambre cristia- na, como Morenglos, y datables en torno al s. X, hace pensar en la coexistencia de musulmanes con cristianos no islamizados de tradición hispanogoda, que podríamos denominar "mozárabes". Estamos frente a patrones de asentamiento del campesinado y no de las elites (...) Uno de los enclaves habitacionales de tipo diverso que aparecen en nuestro territorio es el de las Cuevas de los Corrales, que como he dicho presenta una amplia secuencia ocupacional (...) Además representa uno de los ejemplos de hábitat rupestre más claros de toda esta zona. Ocurre que su carácter eremítico es bastante claro. Este sistema de habitación estaría en consonancia con los patrones de hábitat disperso propuestos para esta zona. (DAZA, 2005-2006: pp. 200-201)

La investigación de Enrique Daza le ha llevado a concluir que existe una clara intencionalidad por parte de las poblaciones a la hora de elegir áreas de areniscas para su asentamiento. Se debe a que esta piedra ofrece unas óptimas características para ser trabajadas con cierta facilidad, adecuándose a las necesidades que estos grupos, interpretados como eremíticos, tenían:

En la sierra norte contamos con varios sitios arqueológicos que pueden ser considerados espacios de hábitat o aldeas de tipo semirrupestre, en las que se manifiesta unas estructuras de poblamiento que combinan la excavación de subestructuras en la roca con estructuras construidas. Muchas de ellas manifiestan una técnica edilicia basada en los materiales perecederos que, combinada con el moldeado de la roca (ya sea para excavar habitaciones, alacenas o simplemente, mechinales), proporcionando a estas obras un carácter pobre, en

\footnotetext{
49 Además, realizó un trabajo de fin de Máster en la Universidad Autónoma de Madrid, bajo la dirección de Jorge López Quiroga, que está en prensa, y lleva por título «Poblamiento rural de la sierra Norte de Guadalajara durante la Alta Edad Media. Cristianización, islamización y repoblación (siglos V-XII)». El libro se anuncia en la página web de la editorial «La Ergástula», si bien no tiene fecha de publicación. También se anuncian otro del mismo autor que podría ser de gran interés, como el titulado «El Castillo de Jadraque en la historia» del que son autores el citado Enrique Daza Pardo y Gonzalo López-Muñiz Moragas, o uno coordinado por Miguel Ángel García Valero titulado «Intervenciones arqueológicas en los Castillos de Guadalajara». Se pueden ver en: http://www. laergastula.com/index.php?option=com_content\&view=section\&layout=blog\&id=26\&ltemid=62 (Última consulta Octubre 2013)
} 
cuanto a materiales o costes, pero adecuada a los usos para los que se encontraban destinados. (DAZA, 2007c: p. 14)

Como el mismo autor señala, el principal problema del estudio de este tipo de estructuras rupestres es la ausencia de datos fiables acerca de su cronología, ya que ni se han localizado cerámicas en su entorno, ni hay estratigrafías en las cuevas documentadas o en otras de la zona. Por ello debemos tomar con cierta cautela algunas de las propuestas que se plantean sin que necesariamente haya que negarlas.

En lo que respecta a los asentamientos en altura, su estudio propone la identificación de algunos yacimientos hasta ahora desconocidos, como los dos de Bujalaro, otro en Cendejas de la Torre y otro más en Palmaces de Jadraque. En segundo lugar, propone un interesante y necesario cambio de perspectiva: ya no se trata de estudiarlos per se, sino que, de acuerdo con los marcos historiográficos ya planteados en muchas otras partes de la península, se considera que

estudiando los hábitat fortificados en altura localizados en torno a estos pueblos, podremos conocer la secuencia histórica de las poblaciones a lo largo de la edad media, los movimientos de los hábitat dentro del territorio, en función de las necesidades del momento. Es aqui donde las fortificaciones, de tipo aldeano a priori, se demuestran como los principales elementos morfogenéticos del poblamiento medieval del valle del Henares (DAZA, 2007a: pp. 13-14).

Es decir, se estudian los castillos, pero como el indicador más visible del poblamiento, que es lo que se sitúa en el centro del debate. Así, la tesis de este investigador es que la conquista musulmana respetó los asentamientos previos en las inmediaciones de las vías de comunicación, y que los asentamientos propiamente andalusíes aparecieron en torno a los inicios del siglo X, salvo algunas excepciones contadas que lo hicieron con anterioridad. Siguiendo su planteamiento, la tendencia general es la del mantenimiento de una población hispanorromana anterior, que subió desde el valle al espacio de altura más cercano, y no lo abandonó hasta el alejamiento de la frontera musulmana, después del siglo XII. Según él, el poblamiento de esta comarca no fue abundante, al contrario, pero estaba allí cuando llegó la conquista cristiana, que sustituyó la élite dominante en algunos casos, y que fue la base de la población subsiguiente de esta zona. Además, cruzando la información proveniente del estudio de la arquitectura rupestre, Enrique Daza llama la atención sobre el uso de la madera, junto a la piedra, en estos asentamientos fortificados. Pero, siendo la madera un material que desaparece sólo es posible rastrearlo por las oquedades que deja donde se apoyaron los troncos que sirvieron de elementos estructurales básicos a estas arquitecturas, tanto en las torres como en las empalizadas.

Finalmente, una última consideración sobre la propuesta de Daza Pardo tiene que ver con su clasificación de todos estos asentamientos. Evidentemente, no todos fueron iguales, ni tuvieron la misma importancia administrativa ni presentaron la misma fisonomía, y por tanto, su papel en la estructuración del territorio no debió ser la misma. Es por ello por lo que se propone una distinción entre las grandes fortificaciones, destacando Atienza; unos espacios de hábitat fortificado en altura de tipo menor, siendo Riba de Santiuste el ejemplo; castros de asentamientos prerromanos reocupados, de entre los que menciona la Casilla de Moros en Membrillera y el castillo de Nublares en Bujalaro; las fortificaciones asociadas a despoblados, como son Jadraque o el castillo de Iñesque en Angón; y finalmente las aldeas fortificadas, de entre las que destaca Cendejas de la Torre, Castejón de Henares, Bujalaro, Miedes de Atienza, Mandayona o Alcolea de las Peñas. Esta preocupación por clasificar los diferentes tipos de asentamientos permite empezar a entender la complejidad del poblamiento, que no se resume en el simple trinomio castillostorres-aldeas. Este tipo de clasificaciones son, además, una de las características de la historiografía sobre la marca media andalusí 
en estos inicios del siglo XXI (BUENO, 2005 y 2008; ZOZAYA, 2007; SERRANO-PIEDECASAS, 2007, MALPICA y GARCÍA-CONTRERAS, 2010; GARCÍA-CONTRERAS, 2015; ALEJANDRE, 2014) y que, con otros rasgos, ya años antes había utilizado Nuria Morère (MORÈRE, 1983).

El principal problema que notamos en los trabajos de Enrique Daza, dejando a un lado la escasa dimensión social y sobre todo económica con la que se refiere a este poblamiento, es la falta de secuencias estratigráficas que ayuden a corroborar sus propuestas, que cambiarían sustancialmente si, por ejemplo, los hábitat rupestres no tuvieran una secuencia andalusí y por lo tanto no hubiera población mozárabe, o si algunos asentamientos en altura no llegaran más allá del siglo VIII o realmente fueran fundaciones del siglo XII y no anteriores. No es un problema que debamos achacar exclusivamente a él, quien por otro lado ha tratado de superar estos problemas en la medida de lo posible y mucho más que otros investigadores, interviniendo mediante excavación en otros muchos lugares de la provincia (o incluso en la propia Sigüenza, como después veremos) y tratando de comparar los materiales cerámicos o las técnicas constructivas de las arquitecturas emergentes. La ausencia de la dimensión socio-económica es más bien un problema latente, estructural, y no superado en el norte de Guadalajara, a pesar de lo cual, como estamos viendo, los avances en las consideraciones sobre el poblamiento están siendo notables.

Una excepción a esta «arqueología sin excavación» que es la tónica dominante en el norte y noreste de Guadalajara lo constituyen los trabajos de Ernesto García-Soto y las excavaciones llevadas a cabo en el propio urbanismo de Sigüenza. Del primero debemos destacar, en primer lugar, el caso del poblado de los Casares, en Riba de Saélices. Ya veíamos al hablar del periodo de principios del siglo XX, como en las investigaciones llevadas a cabo en la cueva fundamentalmente por prehistoriadores, se habían localizado también algunos restos medievales a los que no se les había prestado demasiada atención. Será a partir de 1998 cuando se plantee un proyecto integral del patrimonio arqueológico de la localidad, incluyendo el estudio exhaustivo de diversos yacimientos, y tomando por centro la cueva de Los Casares (en Riba de Saélices). Desde entonces, se han realizado distintas investigaciones que han sacado a la luz el que es el único asentamiento rural andalusí excavado de todo el noreste de Guadalajara (GARCÍASOTO y FERRERO, 2002, 2007a; GARCÍA-SOTO, FERRERO y GUILLÉN, 2004). Según Ernesto García-Soto y su equipo, se trata de un despoblado de época andalusí, de aproximadamente $6000 \mathrm{~m}^{2}$, que ocupa la media ladera bajo la cueva. Dentro de ésta se identificó un aljibe a mediados del siglo XX, como ya se dijo páginas atrás. El poblado consta de viviendas y distintas estancias, y toda una serie de infraestructuras que nos indican un alto grado de autonomía económica en la aldea, que constaba incluso de un horno de yeso y un silo para guardar grano. Además, parece que no estuvo amurallada, o al menos no se han localizado evidencias en este sentido. El único elemento fortificado es el torreón que corona el cerro, por encima de la cueva, que ya había recibido la atención de otros investigadores con anterioridad (ALMAGRO, 1976). Aunque este poblado ha tratado de relacionarse con el medio físico en el que se inserta, e incluso se ha planteado una posible relación con las salinas que hay a unos kilómetros al oeste (GARCÍA-SOTO y FERRERO, 2006), no son muchos los resultados presentados, ni entran a formar parte de la interpretación que se ha dado del mismo. Por ejemplo, no se presenta la cerámica en su secuencia estratigráfica, lo que hubiese aportado una redimensión de los materiales provenientes de prospección de otros yacimientos por comparación analítica (GARCÍA-CONTRERAS, 2013a y 2016b) No obstante, se muestra un cierto cambio en las consideraciones generales sobre el poblamiento, afirmándose que:

...el patrón de asentamiento de los grupos beréberes en la Meseta (...) se basaría en pequeñas comunidades autónomas con estructuras clánico-tribales y formas de propiedad y explotación comunal del territorio, y que ligadas a él se encargarían de defenderlo de agresiones interiores 
y exteriores. Es decir, se trataba no sólo de reforzar militarmente la retaguardia fronteriza, sino de establecer en ella una población estable que garantizase el dominio de la región lo que dificultaría aún más las incursiones procedentes del exterior. (GARCÍA-SOTO y FERRERO, 2002: p. 525)

La investigación en Los Casares, junto con el contexto de renovación de la arqueología a principios del siglo XXI, impulsó al propio Ernesto García-Soto ha realizar una revisión acerca del conocimiento sobre el poblamiento andalusí en la comarca de Sigüenza (GARCÍA-SOTO, 2005), así como a continuar con la investigación de este periodo en la región, realizando excavaciones en algunos otros puntos, como en el cerro de la Quebrada, junto a Sigüenza (GARCÍA-SOTO y FERRERO, 2008). Además, esta revisión de conjunto ha permitido incorporar los hallazgos islámicos un tanto fortuitos que han aparecido en el curso de las investigaciones que estaban inicialmente dirigidas a otras cronologías. Es el caso del yacimiento de Castilviejo, entre Guijosa y Cubillas del Pinar, un poblado de la Edad del Hierro con una fase islámica conocida desde hace tiempo (DEAMOS, BALBíN y FERNÁNDEZ, 1978) en el que se ha identificado un torreón que ha tratado de integrarse contextualmente con otros restos andalusíes de la zona (GARCíASOTO, 2009). Con todo esto, se han podido replantear algunas consideraciones sobre el poblamiento, sobre todo considerarlo como eminentemente rural y fundamentalmente relacionado con las propias actividades productivas y económicas. Así lo dice el propio Ernesto García-Soto en una selección de párrafos que hemos escogido:

En primer lugar las altas cuencas del Henares, Tajuña y Tajo parecen tener sobre todo a partir de finales del S. IX una población fuertemente asentada en el territorio. En segundo, parece claro que éstas sirvieron de base operativa a las incursiones de los ejércitos califales hacia Castilla y Aragón, e igualmente tuvieron que soportar con frecuencia los ataques de gentes procedentes de más allá del Sistema Central que obligaron a los gobernantes cordobeses a reforzar sus defensas (...) las tierras del norte de Guadalajara tuvieron para los gobernantes cordobeses un gran valor estratégico y económico que les incitó a defenderlas a través de un complejo sistema de fortificaciones (...)

Así pues a lo largo de los valles del Henares, Tajuña y Tajo nos encontramos con indicios claros de gentes establecidas en poblados de diferente tamaño como ocurre en Atienza, Santiuste, Sigüenza, Océn o Los Casares, a los que se añadirían otros cuyo origen islámico nos lo desvela la toponimia como Alboreca, Alcolea de las Peñas y del Pinar, Alcuneza, Algora, Baides, Bujalaro, Bujalcayado, Bujarrabal, etc., que nos muestran una densidad considerable de asentamientos islámicos en el área. (...)

... la mayor parte del contingente de población de la zona, al igual que en otras comarcas de la Meseta Sur, tendría un origen bereber. También es fácil inferir que su ocupación principal sería la agricultura cerealista y la ganadería que alcanzaría un desarrollo si no notable sí, al menos, con unos rendimientos muy superiores a los de las inmediatas regiones septentrionales. A estas actividades se unirían quizás otras de carácter industrial como la explotación de los manantiales salinos tan abundantes en la comarca, por ejemplo, Imón, La Olmeda, Rienda, Paredes, Bujalcayado o Santiuste. Tantas posibilidades económicas atraerían la codicia de las gentes de más allá de la Cordillera Central que de forma regular realizarían algaradas contra este territorio... (GARCÍA-SOTO, 2005: pp. 14-15, 17 y 18)

E, incluso, aunque se le sigue dando una gran importancia al hecho fronterizo, el discurso acerca de las fortalezas, y sobre todo sobre las torres, se complica, y ya no son tratados como una mera línea que los omeyas instalan para evitar la penetración de los cristianos, sino que 
... el entramado existente entre el Henares y el Tajo no parece responder a esta necesidad. En primer lugar la zona carece de los grandes centros militares citados y, aunque es cierta la existencia en la misma de una red de atalayas como las halladas en las cercanías de Atienza, Sigüenza, Horna y Membrillera, nunca tuvo la densidad que aún podemos advertir en el sur de la provincia de Soria. No obstante un detenido trabajo de prospección nos ha permitido localizar entre ambos ríos una considerable densidad de fortificaciones de forma cuadrangular (...) Estas fortificaciones tienen varios aspectos en común, por lo pronto el escaso nivel de visualización entre ellas (...) Incluso algunas están situadas en lugares llanos junto a los caminos que nos indican la existencia de posibles puestos de guardia cuyas funciones serían de carácter fiscal y policial, evitando el contrabando de mercancías y dando seguridad a los viajeros y comerciantes entre otras funciones. Por otra parte estos bastiones podrían tener otra utilidad de carácter represivo y disuasorio, ya que la presencia efectiva de una fuerza militar organizada serviría para impedir posibles sublevaciones y desobediencias al poder central. (GARCÍA-SOTO, 2005: pp. 20-21)

Aun así, se sigue dando primacía a la construcción de estos torreones por parte del poder central o de los beréberes que se enfrentan a él. En una publicación posterior a la citada, García-Soto y Ferrero Ros afirman, incluso contradiciéndose en parte con lo anterior, que

En este contexto histórico surgirían de forma paralela sobre todo en los valles del Jalón y del Tajo una serie de pequeños núcleos fortificados, que apoyados en las grandes fortalezas de la zona como, Atienza y Medinaceli tendrían una doble finalidad de una parte evitar las acometidas de los castellanos desde el norte y de otra controlar un territorio al parecer poblado mayoritariamente por gentes de origen bereber cuya fidelidad al régimen califal en modo alguno estaba asegurada.

Así pues se construye una red perfectamente interconectada de torreones cuadrangulares situados en zonas ligeramente elevadas para controlar los caminos, apoyada por otra red de atalayas ubicadas en altos cerros cuyo fin era la de comunicar posibles incursiones provenientes del norte del Duero. (GARCÍA-SOTO y FERRERO, 2008: p. 273)

De toda esta renovación de la arqueología en la comarca seguntina tampoco se han escapado los espacios urbanos de algunos pueblos, e incluso la propia capital, Sigüenza. De los pueblos, lamentablemente, son sólo dos de los que podemos hablar: Palazuelos (LÓPEZ-MUÑIZ, 2006; VELA y VILLAFRUELA, 2002; GÁMEZ y TORRES, 2005; TORRES y GÁMEZ, 2012) ${ }^{50}$ y Atienza (MUÑOZ, 2008) ${ }^{51}$, y en ninguno de los dos se ha intervenido arqueológicamente en niveles andalusíes, por lo que poco podemos señalar para nuestro interés. En cuanto a Sigüenza, en los últimos años se han llevado a cabo las primeras excavaciones estratigráficas, como apuntábamos antes (síntesis en MARTÍNEZ y RUIZ, 2008; y en GARCÍA-CONTRERAS, 2014). Éstas se han realizado en lugares especialmente sensibles, susceptibles de aportar estratigrafías completas de las que extraer información útil para conocer toda la secuencia histórica de la ciudad, y tener por fin argumentos empíricos desde los que plantear análisis históricos. Destacan, por ejemplo, la intervención llevada a cabo junto al monasterio de Nuestra Señora de los Huertos, el supuesto emplazamiento del núcleo de población mozárabe de tradición visigoda (FERRERO y GARCÍA-SOTO,

50 http://www.castillodepalazuelos.es/ (Última consulta diciembre 2015)

51 Además de en la muralla, en Atienza se ha hecho una excavación en la judería situada en la parte baja del pueblo, un cerro independiente del resto del urbanismo, separado por la carretera de acceso al mismo. Las evidencias de esta excavación, (sondeos aún sin cubrir y los montones de tierra con material arqueológico) las hemos podido ver in situ en nuestras visitas a Atienza, la ultima vez en mayo de 2011, pero no conocemos ninguna publicación al respecto. 
2007); o en los niveles intermedios de la loma en la que se asienta Sigüenza, en las calles próximas a la Catedral e incluso en el mismo claustro (CRESPO y CUADRADO, 2002; VEGA et alii 2008; VELA et al, 2008) o en la más antigua necrópolis de a ciudad, fechada justo después de la conquista cristiana y localizada junto a la misma catedral (CARTín y CUADRADO, 1998). En ninguna de estas intervenciones se han identificado restos que puedan adscribirse al periodo andalusí, por lo que la cuestión del lugar de Sigüenza en época islámica sigue abierta, aunque recientes interpretaciones (GARCÍA-CONTRERAS, 2014) apuestan por una dispersión del poblamiento en torno a un asentamiento de altura localizado en Villavieja, un cerro vecino a Sigüenza al que ya nos hemos referido anteriormente.

Con toda esta renovación arqueológica de la que venimos hablando, el interés por el periodo andalusí se ha ido acrecentando en la provincia. Con ello se ha posibilitado que, aunque aún de manera algo tímida, se puedan ir incorporando datos fragmentarios o restos arqueológicos que se pensaban un tanto descontextualizados dentro de esquemas de interpretación del poblamiento más generales, como ocurre en el caso de Torresaviñán (BARBAS, 2006 y 2009).

Dejando a un lado la práctica arqueológica, en lo que se refiere a la investigación histórica más tradicional, realizada fundamentalmente a partir de la documentación escrita, prácticamente no se ha avanzado mucho respecto a etapas anteriores en estos últimos quince años. Hay que llamar la atención sobre algunos trabajos que, en el contexto más general de la Marca Media, proponen utilizar la información toponímica para rastrear el poblamiento árabe (CHAVARRÍA, 2007; RANZ y LÓPEZ, 1999, 2001 y 2002) o incluso las referencias sobre la vida de personajes relevantes como indicador para aproximarnos de una manera un tanto distinta a la jerarquía del poblamiento, destacando, fundamentalmente, los núcleos urbanos de Guadalajara y Medinaceli. En este sentido, solo Atienza aparece en algunas ocasiones mencionado como lugar donde vivió algún personaje de relevancia, lo que sería indicativo de la importancia del lugar (MARíN, 1995).

En 2009 se publicó una extensísima monografía sobre la comarca, obra de Pedro Olea. El interés de su trabajo va encaminado fundamentalmente a realizar un estudio histórico de las estructuras y grupos de poder a partir del siglo XII: el episcopado y los obispos, el cabildo, la cultura oficial a través del arte eclesiástico, o la legislación de fueros, privilegios etc. No obstante, realiza previamente un amplio estudio, que no cabe llamar introducción porque abarca más de 150 páginas, en el que hace un recorrido desde la prehistoria hasta el momento mismo de la conquista castellana. Centrándonos en la época islámica (OLEA, 2009: pp. 137-167 y 169-178), el autor marca el hecho fronterizo de nuevo como explicación de la existencia de los numerosos yacimientos que cita, fundamentalmente castillos y torres. Es de destacar el uso que hace tanto de fuentes publicadas tanto árabes como de las leonesas y castellanas. Así mismo, cobra un papel importante la existencia de las vías de comunicación de época romana que se mantendrían durante el medioevo, fundamentalmente aquella que unía Emerita con Caesaraugusta (algo ya señalado por MANZANO, 1991). Destaca también en su trabajo el esfuerzo que hace por insertar el territorio seguntino dentro de la comarca que encabezaba Medinaceli en época andalusí, y así, hacer referencia a zonas del sur de Soria siempre que lo considera necesario, no limitándose a la provincia de Guadalajara, como sí ocurre en otros trabajos antes mencionados. No obstante, a nivel interpretativo y explicativo, en tanto que su trabajo en estos aspectos previos a la conquista feudal es más de recopilación que de investigación básica, no es mucho lo que podemos destacar.

Algo parecido ocurre con otras obras de carácter e interés fundamentalmente local. Nos referimos a las que realizan historiadores en su mayoría fuera de los círculos académicos histórico-arqueológicos (esos que a menudo solemos llamar «eruditos locales»). Estos se han ido haciendo eco de la importancia de narrar también el periodo islámico en las historias de los pueblos. Así, sea a modo 
de prólogo o sea como un capítulo propio, y partiendo de los restos arquitectónicos cuando los hay o de alguna referencia documental, tratan de presentar brevemente una panorámica sobre el periodo andalusí. Pero a menudo siguen cayendo en manidos tópicos, a menudo superados, ya que no se manejan bibliografías recientes, sino los trabajos más antiguos, al menos por lo general. Aún con todo, son trabajos dignos de reseñar, que aportan datos hasta ahora desconocidos o se atreven a aventurar hipótesis que deberán ser confirmadas en el futuro. En este sentido, destaca especialmente la labor de la editorial Aache que dirige Antonio Herrera como cronista oficial de la provincia ${ }^{52}$, que está editando muchas pequeñas obras de cada uno de los pueblos de la provincia de Guadalajara, en los que se recogen los restos arqueológicos existentes y las referencias de las fuentes documentales (por citar sólo algunas del territorio que nos ocupa: ORTIZ y RUBIO, 2000; GARCÍA, 2008; SERRANO, 2008). Quizás el problema es que muchas de estas obras no tienen gran densidad, limitándose a presentar de manera descriptiva sin incorporar análisis o debates históricos de calado. Aún así, hay que reconocer en su justa medida las aportaciones que proporcionan.

Igualmente, debemos referirnos a otro tipo de historia también de carácter e interés local, pero con capacidad de trascender y llegar mucho más allá, incluyendo incluso las investigaciones académicas. Se trata de las publicaciones que podemos encontrar en blogs o páginas web, actualizados con cierta periodicidad, y que tratan de temas históricos y arqueológicos de distintas localidades. A priori, podría pensarse que los trabajos que se presentan pueden carecer del rigor deseable, o que no se insertan en las líneas historiográficas y los debates históricos al uso. Pero aún siendo cierto, en ello reside parte de su novedad y su valor, porque en ocasiones plantean interesantes interrogantes, y sobre todo, porque muestran un profundo y denso conocimiento de los medios rurales, en los que a menudo viven los autores de estas publicaciones, que escapa con mucho al conocimiento que pueden tener los investigadores académicos que se acercan eventualmente a esta comarca. Este denso conocimiento local les lleva a presentar fotografías antiguas de yacimientos o de materiales cerámicos recogidos en superficie. Evidentemente, nos vemos obligados a poner en duda el rigor y la veracidad de algunas de las cuestiones que en estos medios se tratan, pero no dejan de ser un interesante medio alternativo de información histórica y patrimonial. De entre los que se dedican, de manera más o menos directa, a la zona que estudiamos ${ }^{53}$, conviene destacar sobre todo uno, el sitio «histgueb», gestionado por Marcos Nieto, dedicado a la historia de Sigüenza y algunos pueblos de su entorno y con licencia Creative Commons ${ }^{54}$. En sus publicaciones, presenta detalladísimos estudios acompañados de fotografías, croquis y planimetrías, e incluso fotografías de documentos originales o de restos arqueológicos, sobre distintos aspectos de la historia de la comarca de Sigüenza. La importancia de sus trabajos queda patente desde el momento en el que son referidos y reconocidos, así como contrastados y en ocasiones corroborados, en trabajos académicos que pueden tener un mayor bagaje científico-técnico (ECHEVARRÍA, 2009: 191; GARCÍA-CONTRERAS, 2013a)

Uno de los mayores impulsos al conocimiento del periodo andalusí en esta región ha venido de la mano de un proyecto de investigación centrado en relacionar el poblamiento histórico con la explotación de la sal (MALPICA et alii, 2008, 2011a y 2011b), a partir del cual se ha desarrollado una tesis doctoral y diferentes publicaciones centradas

\footnotetext{
52 http://www.aache.com/ (Última consulta enero 2016)

53 Podemos citar el blog «Entre Sigüenza y Berlanga» (http://berguenza.blogspot.com.es/); el blog «De viaje por Guadalajara» (http:// miarticulodehoy.blogspot.com.es/) una página web dedicada al castillo de Riba de Santiuste (http://www.castillodelariba.com/); y otra página dedicada al pueblo de Alcolea de las Peñas y los yacimientos arqueológicos de su entorno (http://www.barahona. org/alcolea/).

54 http://www.histgueb.net/ (Última consulta en febrero 2016)
} 
en el periodo andalusí en la región del Alto Henares (GARCÍA-CONTRERAS, 2009, 2010, 2012a, 2012b, 2012c, 2013a, 2013b, 2014, 2015, 2016a, 2016b). Es un proyecto que recoge, de alguna forma, toda la tradición anterior sobre el poblamiento andalusí de la comarca, recogiendo los reclamos sobre la necesidad de estudiar el paisaje y la explotación de los recursos naturales (FERNÁNDEZ, 2001; OLMO, 2002) y combinándola con el interés por las salinas históricas de la región (MORÉRE, 1991, 2008a; ECHEVARRÍA, 2009). Aunque toda esta investigación haya podido mejorar en mayor o menor medida el conocimiento que sobre el periodo andalusí se tenía en esta área del centro peninsular (por ejemplo localizando nuevos asentamientos como el de Bonilla, en La Olmeda de Jadraque), el problema sigue siendo el mismo ya planteado páginas atrás: sigue sin haber excavaciones estratigráficas, por lo que muchas de las ideas que pudieran plantearse siguen moviéndose en el plano de la hipótesis (Fig. 6).

De manera paralela al proyecto y la tesis anteriormente citados, en la vecina región de Medinaceli, al sur de Soria, pero parcialmente dentro también de este extremo oriental del Sistema Central, se ha desarrollado otra tesis doctoral con unos postulados teóricos y

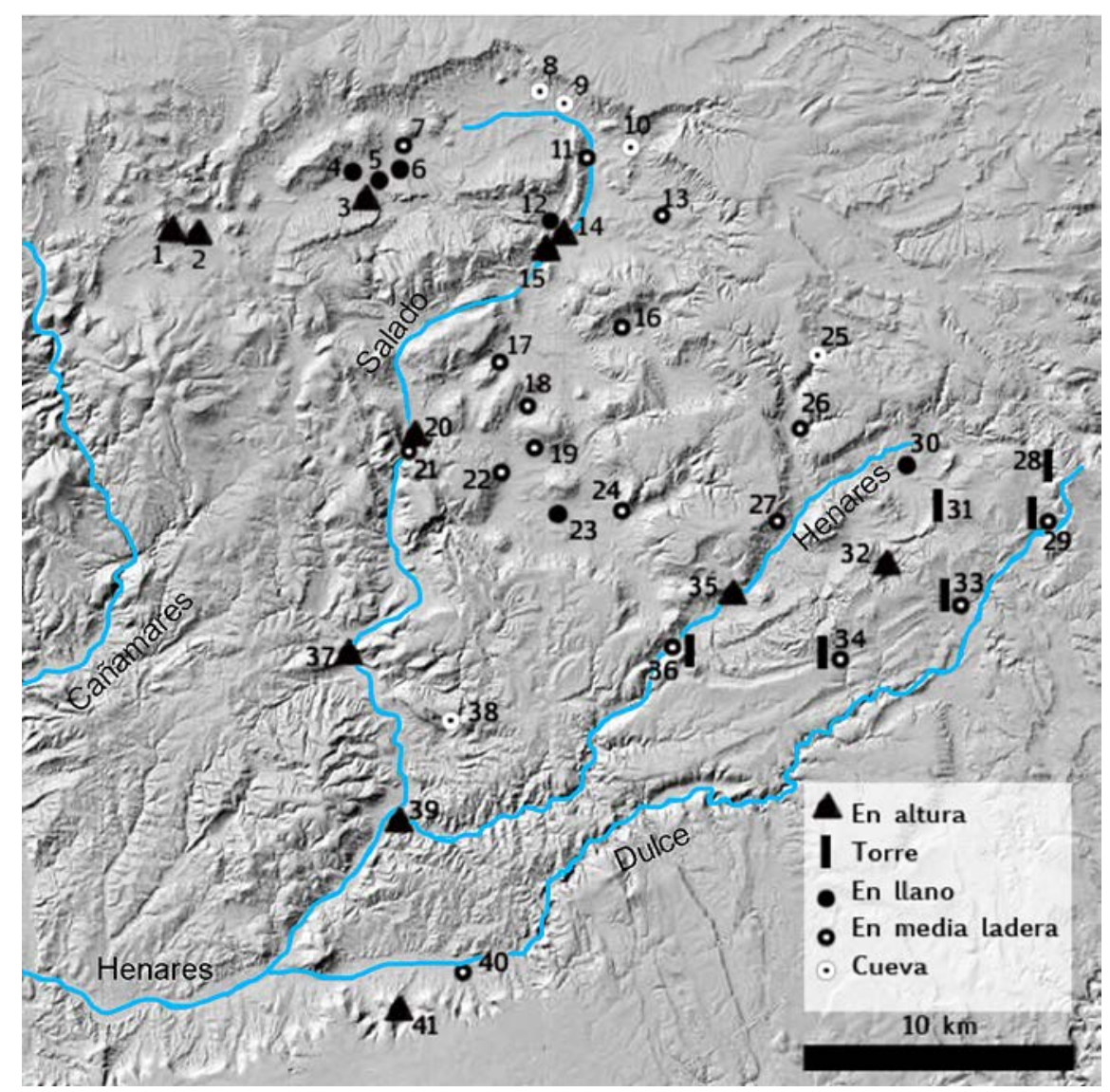

Fig. 6. Mapas de asentamientos califales en los valles del río Salado, el Alto Henares y el río Dulce distinguiendo en altura, en media ladera, en el llano, torres y cuevas. (Modificado a partir de GARCÍA-CONTRERAS, 2013: p. 700). 1) Cerro Padrastro, 2) Atienza, 3) Alcolea de las Peñas, 4) Cerrada de las Monjas, 5) Llano de los Pericales, 6) Morenglos, 7) Cantos Blancos, 8) Los Poyatos, 9) Las Viñas, 10) Mochara, 11) Torrequebradilla, 12) La Alquería, 13) Las Aldehuelas, 14) Riba de Santiuste, 15) El Castillejo de la Riba, 16) Villacorza, 17) La Asomadilla, 18) Cerrillo de las Monjas-Almijeras, 19) Bujalcayado, 20) Santamera, 21) La Espinà, 22) Bonilla, 23) Fuente de Romanones, 24) Castillejo de Ures, 25) Cueva Harzal, 26) Alboreca, 27) Alcuneza,

28) Torrevera, 29) Bujarrabal, 30) Ermita de los Quintanares, 31) Castilviejo de Guijosa, 32) El Villar, 33) La torrecilla de Estriégana, 34) Barbatona, 35) Villavieja, 36) La Quebrada, 37) Huérmeces, 38) Cueva del barranco de la Hoz, 39) Baides, 40) Mandayona, 41) Castejón de Henares 
metodológicos muy similares (BUENO, 2011a). Tanta es la semejanza, que algunas conclusiones de trabajos posteriores (BUENO, 2012: pp. 424-425) parecen ser casi una copia literal de lo dicho por otros en trabajos anteriores (GARCÍA-CONTRERAS, 2009: p. 219)

Aún es demasiado pronto para poder valorar el impacto de estos últimos estudios por lo recientes que son. Pero no cabe duda que están suponiendo un acicate y un cambio de perspectiva de cierto calado en la historiografía arqueológica sobre el periodo andalusí en la zona. El hallazgo de nuevos asentamientos, sobre todo rurales pero también en altura (BUENO, 2008; MALPICA y GARCÍA-CONTRERAS, 2010; GARCÍA-CONTRERAS, 2009) datados a partir de las cerámicas recogidas en superficie o provenientes de excavaciones arqueológicas (BUENO 2010, 2011c, GARCÍA-CONTRERAS, 2010 y 2016b), junto con una nueva reinterpretación en clave fronteriza incluyendo también los yacimientos ya conocidos, tanto fortalezas como torres (BUENO, 2011b, 2012a, 2012b, GARCÍA-CONTRERAS, 2015, 2016a), tratando de ponerlos en relación con las salinas que pudo haber en época andalusí (GARCÍACONTRERAS, 2013b), están llevando a plantear modelos de organización social del espacio y articulación y jerarquización del poblamiento que si bien no son excesivamente originales en el conjunto de al-Andalus, sí que suponen una novedad en la región, y están permitiendo que esta se incorpore a los debates históricos y arqueológicos más generales (BUENO, 2016, GARCÍA-CONTRERAS, 2012c, 2015, 2016a). A ello debemos añadir también un renovado interés por los contextos paleoambientales, que está contribuyendo a una redefinición de lo que debió ser el paisaje en época de alAndalus (CURRÁS, 2012, CURRÁS et alii, 2012; GARCÍA-CONTRERAS, 2012b)

\section{Recapitulación}

Con la reconquista, Guadalajara entra a pie llano en el trillado campo de la Historia (LAYNA, 1942: p. 27).

La historia conocida, documentada y cantada por los poetas de Sigüenza, comienza en los albores del siglo XII, con la Reconquista cristiana en la zona (HERRERA, 1991: p. 16)

Con estas dos frases, primero las palabras de Layna Serrano a principios de los años cuarenta y después las de Herrera Casado a principios de los noventa, se podría sintetizar, en gran medida, el problema del conocimiento del periodo andalusí en el territorio que hemos analizado, ya que los siglos VIII al XII han estado, hasta hace muy poco, en «las afueras del medievalismo», (parafraseando a BARCELÓ et alii, 1988). Y ello debido, en gran medida, a la escasez de referencias documentales y al retraso con el que se ha incorporado la provincia al estudio arqueológico de los restos medievales. A ello habría que sumar el acomodo de la historiografía a las líneas maestras de los historiadores de la primera mitad del siglo XX, fundamentalmente Manuel Pérez-Villamil, Juan Catalina García López, Fray Toribio Minguella y Francisco Layna Serrano. Salvo algunas obras, muy pocas, de corte más histórico, cuando se estudia la fase andalusí del poblamiento en el noreste de Guadalajara se hace, o se tiene que hacer, desde la arqueología, como ya empezaron a poner de manifiesto los trabajos de Nuria Morère, Basilio Pavón o Manuel Retuerce, y como han seguido avanzando y siguen en ello las investigaciones más recientes.

Aunque la escasez de estudios específicos sobre la arqueología andalusí es un hecho generalizado para gran parte del centro peninsular -salvando Madrid-, lo cierto es que existen grandes desigualdades regionales, incluso entre zonas próximas, como ocurre si comparamos dentro de la propia provincia de Guadalajara la propia comarca seguntina que hemos analizado en estas páginas con la vecina de Molina de Aragón que queda al sureste (ARENAS, 2008: p. 17) plasmado cuantitativamente o en el número y localización de las Cartas Arqueológicas (ORTIZ, PANTOJA y SÁNCHEZ, 2010: p. 1120). Y no sólo es un problema regional, sino también temático, ya que determinados periodos o aspectos se ven favorecidos frente a otros que son prácticamente ignorados. Ya lo advirtió en los años 
ochenta Basilio Pavón refiriéndose a la fase andalusí, donde apuntaba que «el fenómeno arqueológico en Guadalajara es escurridizo, con o sin excavación, por la brutal suplantación de que fue objeto, al sobrevenirle encima cuatro largos siglos medievales de cristianismo» (PAVÓN, 1984: p. 9). A nuestro juicio, y con todo lo dicho en las páginas anteriores, pensamos que son cuatro los motivos principales que han dificultado el conocimiento de al-Andalus en este territorio:

1. A nivel teórico, la imposibilidad de usar el periodo andalusí como justificante histórico del «ser» impertérrito de la zona estudiada, junto con otros factores historiográficos que provienen de antiguo y tienen más que ver con la «esencia» de la historia de España, como veíamos páginas atrás. Frente a ello, la pertenencia a la «Celtiberia» o la importancia del elemento visigodo en la justificación del nacional-catolicismo español, potenciaron un mayor interés por estos periodos desde principios del siglo XX.

2. A nivel estratégico: la ausencia de una universidad o institución fuerte en la zona que haya promovido investigaciones. La zona ha sido estudiada mediante proyectos de investigación provenientes de universidades de fuera, principalmente de Madrid. Eso ha hecho que sean las zonas con mejor acceso o en el entorno de los núcleos de población más grandes, los que estén mejor estudiados, careciendo prácticamente de estudios zonas como el noreste de la provincia (la Sierra Norte propiamente dicha)

3. A nivel estrictamente histórico; la ausencia de documentación específica, en parte por ser una región fronteriza al margen de los grandes núcleos de poder, pero en general es la tónica dominante en al-Andalus. Esto ha hecho que en los estudios a partir de las fuentes escritas se reiteren una serie de temas, como el hecho fronterizo, la presencia de determinadas tribus beréberes, o los cambios en el poblamiento a partir del traslado de la capitalidad de la
Marca Media de Guadalajara a Medinaceli. Junto a ello, algunos estudios toponímicos empeñados en localizar los lugares mencionados en la documentación, tanto árabe como de las incursiones cristianas. Y con dificultad, se han planteado otro tipo de interrogantes que no estuvieran ya previamente consignadas en la propia documentación que se estudiaba.

4. A nivel arqueológico, la práctica inexistencia de excavaciones arqueológicas, y cuando se han hecho, no cuentan con sólidas secuencias estratigráficas válidas para época andalusí o no han sido publicadas; y derivado de ello las dificultades para identificar la cultura material del periodo andalusí, mal definido sobre todo en sus fases más tempranas. En general, ocurre igual con todo el periodo alto y plenomedieval en aquellas zonas donde no se formó una entidad urbana o castral de importancia, o donde los asentamientos en altura no tuvieron continuidad más allá de los siglos XI-XII.

Con todos estos condicionantes, puede entenderse-que no justificarse- que el periodo andalusí haya quedado relegado, no ya a un segundo plano, sino incluso olvidado y ninguneado, al menos hasta fechas recientes. Es algo que se retroalimentó con las ideas que defendían una despoblación estratégica de esta zona volcada únicamente a su vertiente de frontera militar y con la ausencia de documentación escrita y de vestigios arquitectónicos islámicos de envergadura. Es un fenómeno que se repite en otras partes de la Península Ibérica y que, no por casualidad, suele coincidir con las zonas que, por distintos motivos, estaban lejos de los principales centros políticos, culturales y económicos de al-Andalus (por ejemplo, en Extremadura: GILOTTE, 2010: pp. 9-11).

Además de todo lo que hemos señalado anteriormente, otro de los problemas que tienen los estudio sobre esta región es que rara vez han trascendido el ámbito local. Como mucho, se insertan en el conjunto territorial de la Marca Media o de la frontera en general 
(MANZANO, 1991; ALEJANDRE, 2014), pero no siempre se han utilizado en planteamientos generales sobre al-Andalus ni se ha comparado lo que ocurre aquí con lo que ocurre en otras zonas, tanto del norte cristiano como del resto de al-Andalus, lo que hubiera permitido comprender mejor las características específicas o las semejanzas que presenta esta zona. Es algo que ocurre únicamente con el periodo andalusí, ya que tanto en época protohistórica, como en la etapa bajomedieval, lo que ocurre en este territorio sí que ha trascendido y se ha insertado en debates más amplios (por ejemplo para la Baja Edad Media PORTELLA, 1985; MONSALVO, 2003). Se trata, en definitiva, de una falta de diálogo entre la historia local y la historia general tan característica de la investigación sobre al-Andalus.

No obstante, todo este pesimismo parece haberse sacudido en los últimos quince años. La narrativa histórica generada sobre el noreste de Guadalajara en los siglos centrales de la Edad Media a partir de la arqueología había creado hasta finales del siglo XX la imagen de un territorio fronterizo, salpicado de castillos, asentamientos en altura y torres, bajo control musulmán. Tímidamente, y especialmente en los últimos diez años, se ha ido abandonado ya la idea de un espacio despoblado o fuertemente militarizado. Se han ido marcando la existencia de diferentes tipos de poblaciones, como mozárabes y beréberes (los Banū Salìm); y se está empezando a dotar de dinamicidad a una historia que se había presentado demasiado estática hasta ahora. Territorialmente, se señala de manera inconsistente, e incluso en ocasiones contradictoria, la adscripción de estas tierras al área de influencia de Guadalajara o de Medinaceli dependiendo del periodo, y con un mayor o menor peso de los beréberes o el poder central Omeya. Y en cuanto a la organización y jerarquía del poblamiento, se indica la supremacía de Atienza y se empieza a poner en duda el papel de Sigüenza, mientras que se refuerza el de otros núcleos secundarios como Riba de Santiuste o Alcolea de las Peñas. De la misma manera, se están revisando el papel de las torres, ya que no todas ellas fueron atalayas relacionadas con el papel fronterizo. Y quizás lo más importante de todo, se ha comenzado a destacar la existencia y el papel de los asentamientos rurales, relacionados con la explotación de los recursos naturales de su entorno y la creación del paisaje entre los siglos VIII al XII.

Por lo tanto, las perspectivas de futuro en este inicio del siglo XXI resultan ciertamente alentadoras, y muchos de los problemas detectados, a nivel estratégico e institucional, parecen estar solucionándose, mientras que a nivel teórico las propuestas están siendo significativamente sugerentes. No obstante, a pesar de todo ello hay un lastre que debe sacudirse lo antes posible: la escasez y práctica ausencia de excavaciones en yacimientos arqueológicos andalusíes. Sin materiales procedentes de registros estratigráficos y los necesarios análisis realizados sobre ellos, las interpretaciones no pasan de ser meras hipótesis sin contrastación.

En cualquier caso, «show must go on» que decía el bueno de Freddie.

\section{Agradecimientos}

El trabajo tiene su origen en la tesis doctoral realizada bajo la dirección de Antonio Malpica Cuello gracias a la concesión de una beca de Formación de Profesorado Universitario en la Universidad de Granada (2008-2012), y se ha redactado durante el periodo de estancia en la University of Reading gracias a una beca de perfeccionamiento de doctores del Plan Propio de la Universidad de Granada (20142016). El autor quiere agradecer a Manuel Retuerce Velasco y Miguel Ángel Cuadrado las facilidades y permisos aportados para la reproducción de imágenes provenientes de sus respectivos trabajos, así como a Plácido Ballesteros San José por permitir usar las de la revista Wad al-Hayara de la que es director. Igualmente, el autor agradece a los dos evaluadores anónimos por sus correcciones, puntualizaciones y propuestas de mejora que sin duda han enriquecido el texto. 


\section{BIBLIOGRAFÍA}

ABASCAL PALAZÓN, José Manuel y CEBRIÁN FERNÁNDEZ, Rosario (2009): Los viajes de José Córnide por España y Portugal de 1754 a 1801. Madrid

ACOSTA GONZÁLEZ, Andrés (2003): Los grabados de la Cueva de los Casares (Riba de Saelices, Guadalajara). Guadalajara

AGUILERA Y GAMBOA, Enrique de (s.f.): Páginas de la Historia Patria, por mis excavaciones arqueológicas. Madrid, obra inédita

- (1909): El Alto Jalón. Descubrimientos arqueológicos. (reed. en Sigüenza en 1999)

ALEJANDRE ALCALDE, Vicente (2014): El sistema defensivo musulmán entre las Marcas Media y Superior de Al-Andalus (siglos X-XII). Calatayud

ALMAGRO GORBEA Antonio (1976): «Las torres beréberes de la Marca Media. Aportaciones a su estudio», Cuadernos de la Alhambra. 12, pp. 279-305

ANÓNIMO (1959): Historia Silense. ed. y trad. Justo Pérez de Urbel y Atiliano González, Madrid

- (2012): «Cartas arqueológicas», La Pizarra de la Sierra Norte. Revista del grupo de desarrollo rural ADEL. 4, pp. 7-9

ARENAS ESTEBAN, J. Alberto (2008a): «El patrimonio arqueológico del Señorío de Molina», en Ernesto GarcíaSoto Mateos, Miguel Ángel García Valero, y Juan Pablo Martínez Naranjo (eds.), Actas del Segundo Simposio de Arqueología de Guadalajara, Guadalajara. pp. 17-54

ARGENTE OLIVER, José Luis (1977): «Los yacimientos de la colección Cerralbo a través de los materiales conservados en los fondos del Museo Arqueológico Nacional», Actas del XIV Congreso Nacional de Arqueología (Vitoria, 1975). Zaragoza, pp. 587-598

BALBÍN BEHRMANN, Rodrigo de y VALIENTE MALLA, Jesús (1995): "Carta arqueológica de la provincia de Guadalajara», en AA.W. (ed.), Arqueología de Guadalajara. Toledo, pp. 9-24

BALLESTEROS SAN-JOSÉ, Placido (1991): «Historiografía y visión histórica de la Alcarria Baja en la Edad Media durante los siglos XVI al XX», Wad-al-Hayara. 18, pp. 27-71

BANKS, Philip y ZOZAYA, Juan (1984): «Excavations in the caliphal fortress of Gormaz (Soria) 1979-1981: a summary», Papers in Iberian archaeology. British Archaeological Reports. 193, pp. 674-703

BARANDIARÁN MAESTU, Ignacio (1969): «Yacimiento musteriense de la Cueva de Los Casares (Guadalajara)», X Congreso Nacional de Arqueología, Mahón, 1967. Zaragoza, pp. 153-158

- (1971): «La cueva de los Casares (Riba de Saélices, Guadalajara)», Excavaciones arqueológicas en España. 76

BARBAS NIETO, Ricardo L. (2006): «La Torre Saviñán de atalaya árabe a castillo cristiano. La Torresaviñán, Guadalajara», en Amador Ruibal Rodríguez (ed.), Actas del III Congreso de Castellología Ibérica. Guadalajara, pp. 421-446
- (2009), La Fuensaviñán. Legados de la tierra. Madrid

BARCELÓ, Miquel, et alii. (1988): Arqueología medieval. En las afueras del medievalismo. Barcelona

BARCELÓ, Miquel; KIRCHNER, Helena, y NAVARRO, Carmen (1996): El agua que no duerme. Fundamentos de la arqueología hidráulica andalusí. Granada

BATALLA CARCHENILLA, Cesar María (1996): «El camino de la sal. De Santamera a Huérmeces del Cerro (Guadalajara)», en Manuel Criado del Val (ed.), Actas del II Congreso Internacional de Caminería Hispánica. Guadalajara, t. I, pp. 395-400

BERMEJO CRESPO, José Luis y MUÑOZ LÓPEZ-ASTILLEROS, Kenia (1994): «Una explotación agrícola en el territorio de los Banu Salim: excavaciones en la "Vereda de Sedano" o "Las Fuentecillas" (San Fernando de Henares, Madrid)», Boletín de Arqueología Medieval. 8, pp. 205-225

- (1995-1996): «El yacimiento medieval de Vereda de Sedano o Las Fuentecillas (San Fernando de Henares, Madrid): Campañas de excavación de 1989 y 1990», Estudios de Prehistoria y Arqueología Madriñelas. 10, pp. 111-120

- (1996): «La producción cerámica en el entorno del Henares durante los siglos IX y X», Actas del V Encuentro de Historiadores del Valle del Henares. Guadalajara, pp. 79-86

- (1999): «Poblamiento y frontera en los Valles del Jarama y Henares en época islámica», en Rodrigo de Balbín Behrmann y Primitiva Bueno Ramírez (eds.), II Congreso de Arqueología Peninsular, Zamora, del 24 al 27 de septiembre de 1996. Alcalá de Henares, Fundación Rei Afonso Henriques, t. IV Arqueología romana y medieval, pp. 555-560

BLÁZQUEZ GARBAJOSA, Adrián (1985): «La reconquista de Sigüenza y su significación geopolítica regional», Wad-al-Hayara. 12, pp. 35-42

- (1988): El señorío episcopal de Sigüenza: economía y sociedad (1123-1805). Guadalajara.

BOLOIX GALLARDO, Bárbara (2001): «La taifa de Toledo en el siglo XI. Aproximación a sus límites y extensión territorial», Tulaytula. 8, pp. 23-57

BUENO RAMÍREZ, Primitiva; BARROSO BERMEJO, Rosa, y JIMÉNEZ SANZ, Pedro J. (2002): «Culturas productoras, culturas metalúrgicas y grafías en la provincia de Guadalajara. Una revisión historiográfica», en Ernesto García-Soto Mateos y Miguel Ángel García Valero (eds.), Actas del primer simposio de Arqueología de Guadalajara. Homenaje a Encarnación Cabré Herreros. Madrid, pp. $47-64$

BUENO SÁNCHEZ, Marisa (2005): «Fortalezas y atalayas en el entorno del Alberche en los siglos X-XIII. Estado de la cuestión», en Amador Ruibal Rodríguez (ed.), Actas del III Congreso de Castellología Ibérica. Guadalajara, pp. 305-324

- (2008): «Estrategias de supervivencia en época tardoantigua y altomedieval. Reocupación de recintos celtibéricos en el alto Jalón (Soria)», I Jornadas de Jóvenes Investigadores de Arqueología: Dialogando con la Cultura Material, Madrid, t. 2, pp. 485-492 
- (2010): «Cerámica islámica de Medinaceli. Excavaciones de urgencia e investigación (1975-2009)», en Manue Crespo Díez y Raquel Martínez Peñín (eds.), Metodología de análisis aplicada a los estudios de cerámica Tardoantigua y Medieval de la Península Ibérica. León, Lobo Sapiens, pp. 75-89

- (2011a): Territorio y cultura material en el entorno soriano (siglos VII-XII): de la Marca Media a la Extremadura Castellana. Tesis doctoral inédita, Universidad Complutense, Madrid

- (2011b): «Frontières iberiques en discussion: chrétiens et musulmans dans le Duero oriental (VIIIe-XIle siècle)», en Michel Catala, Dominique Le Page, y Jean-Claude Meuret (eds.), Frontières oubliées, frontières retrouvées. Marches et limites anciennes en France et en Europe. Rennes, Presses Universitaires de Rennes, pp. 177-188

- (2011c): «El hilo de Ariadna. El trabajo femenino en la Marca Media oriental a través del registro arqueológico», en Francisco Toro Ceballos y José Rodríguez Molina (eds.), VIII Estudios de Frontera: Mujeres y Fronteras. Jaén, pp. 65-80

- (2012a): «¿Frontera en el Duero oriental? Construcción y mutación de funciones en el Tagir Banū Sālim (siglos VIIIXI)», en Juan Martos Quesada y Marisa Bueno Sánchez (eds.), Fronteras en discusión. La Península Ibérica en el siglo XII. Madrid, pp. 165-190

- (2012b): «Más allá del territorio, tradiciones en el entorno del Jalón», en Belén Arizaga Bolimburu, et alii. (eds.), Mundos medievales: espacios, sociedades y poder. Homenaje al profesor José Ángel García de Cortázary Ruiz de Aguirre. Cantabria, t. 1, pp. 413-425

- (2016): «Power and rural communities in the Banu Salim área (Eight-Eleventh centuries). Peasant and frontier landscapes as social construction» en Fábregas, Adela y Sabaté, Flocel (eds.), Power and rural communities in al-Andalus. Ideological and Material Representations. Brepols, The Medieval Countryside, pp. XX

CABRÉ AGUILÓ, Juan (1934): «Las cuevas de los Casares y de la Hoz», Archivo Español de Arte y Arqueología. 30

CARDÍN, Isabel y CUADRADO, Miguel Ángel (1998): «Avance de los trabajos arqueológicos realizados en la necrópolis de la Catedral de Sigüenza», Actas del VI Encuentro de Historiadores del valle del Henares (Alcalá de Henares, noviembre de 1998). Madrid, pp. 107-128

CHAVARRÍA VARGAS, Juan Antonio (2007): «Onomástica árabo-beréber en la toponimia de Castilla-La Mancha: Guadalajara», Anaquel de estudios árabes. 18, pp. 93-116

CRESPO CANO, María Luz y CUADRADO PRIETO, Miguel Ángel (2002): «Restos de la muralla de Sigüenza en la calle Cardenal Mendoza, 21», en Ernesto García-Soto Mateos y Miguel Ángel García Valero (eds.), Actas del primer Simposio de Arqueología de Guadalajara. Homenaje a Encarnación Cabré Herreros. Madrid, t. 2, pp. 787-800

CUADRADO PRIETO, Miguel Ángel (2002): «Historiografía de la investigación sobre Arqueología Medieval en Guadalajara», en Ernesto García-Soto Mateos y Miguel Ángel García Valero (eds.), Actas del primer Simposio de Arqueología de Guadalajara. Homenaje a Encarnación Cabré Herreros. Madrid, t. 1, pp. 99-113
CURRÁS, Andrés (2012a): Estudio sobre la evolución de paisajes mediterráneos continentales en Lleida y Guadalajara durante los últimos 3000 años a partir de las secuencias polínicas de Ivars, Somolinos y Cañamares. Tesis Doctoral dirigida por Santiago Riera Mora, Universitat de Barcelona. Barcelona

CURRÁS, Andrés et alii (2012): "Climate change and human impact in central Spain during Roman times: High-resolution multi-proxy analysis of a tufa laje record (Somolinos, 1280 m asl)», Catena. 89: 31-53

DAZA PARDO, Enrique (2001): «El castillo del Cid (Jadraque)», Castillos de España. 120, pp. 51-55

- (2003): «Xadrach y Casteion. Origen y desarrollo de la fortaleza del Cid en la Edad Media a través de la Toponimia y la Arqueología », Castillos de España. 131, pp. 34-42

- (2005-2006): «Formas de ocupación rural en la Sierra Norte de Guadalajara (siglos V-X). El despoblado de Morenglos (Alcolea de las Peñas, Guadalajara)», Cuadernos de Prehistoria y Arqueología de la Universidad Autónoma de Madrid. 31-32, pp. 195-218

- (2007a): «Los castillos olvidados. El papel de los asentamientos fortificaciones en altura en la génesis del poblamiento altomedieval del valle del Henares (siglos VII-XII)», Castillos de España. 148, pp. 13-25

- (2007b): «Elementos para el estudio de la Arqueología altomedieval en la Sierra Norte de Guadalajara. Monacato, edilicia y poblamiento», en Jorge López Quiroga, Artemio Manuel Martínez Tejera, y Jorge Morín de Pablos (eds.), Monasteria et territoria. Élites, edilicia y territorio en el Mediterráneo medieval (siglos V-XI). Oxford, BAR International Series S1720, pp. 399-408

- (2007c): «La edilicia rupestre en el norte de Guadalajara: Hábitat y eremitismo en la transición de la Antigüedad a la Edad Media», Codex Aquilarensis. 23, pp. 6-26

- (2013): «La Cárcel de Alcolea de las Peñas (Guadalajara): un ejemplo de fortificación semirrupestre», en Fernandes, Isabel Cristina (ed.), Fortificações e territõrio na Península Ibérica e no Magreb (Séculos VI a XVI). Mércola, t. 2, pp. 781-786

DAZA PARDO, Enrique y CATALÁN RAMOS, Raúl (2009): «Las necrópolis de época visigoda en la provincia de Guadalajara. Una revisión crítica», en Pinar Gil, joan y Juárez Villena, Toni (Eds.), Contextos funeraris a la Mediterrània nord-occidental (segles V-VIII), Gausac. 34-35, pp. 131-143

DAZA PARDO, Enrique; LÓPEZ-MUÑIZ MORAGAS, Gonzalo y VELA COSSIO, Fernando (2013): «Nuevas aportaciones al estudio del castillo de Cogolludo (Guadalajara)», en Fernandes, Isabel Cristina (ed.), Fortificações e territõrio na Península Ibérica e no Magreb (Séculos VI a XVI). Mércola, t. 2, pp. 773-779

DEAMOS, Ma Belén; BALBÍN BEHRMANN, Rodrigo de, y FERNÁNDEZ-MIRANDA, Manuel (1978): «Castilviejo de Guijosa (Sigüenza)», Wad-al-Hayara, 5. pp. 63-87

DÍAZ ANDREU, Margarita (1996): «Islamic archaeology and the origin of the Spanish nation», en Margarita Díaz Andreu y Timothy Champion (eds.), Nationalism and Archaeology in Europe. London, UCL Press, pp. 68-89 
ECHEVARRÍA ARSUAGA, Ana (2005): «La propiedad de los yacimientos mineros andalusíes en el siglo XIl», en Octavio Puche Riart y Mariano Ayarzagüena Sanz (eds.), Minería y metalurgia históricas en el sudoeste europeo. Madrid, pp. 345-350

- (2009): «La minería de la sal en el norte de la meseta: ¿una redefinición de los espacios productivos rurales?», en Iñaki Martín Viso (ed.), ¿Tiempos oscuros? Territorio y sociedad en el centro de la Península Ibérica (siglos VII-X), Salamanca, pp. 181-202

- (2010): «Explotación y mano de obra en las minas y salinas de al-Andalus», Espacio, Tiempo y Forma. Serie III Historia Medieval. 23, pp. 55-74

ESCALONA MONGE, Julio (1989): «Poblamiento y organización territorial en el sector oriental de la cuenca del Duero en la Alta Edad Media», III Congreso de Arqueología Medieval Española. Oviedo, t. II, pp. 448-455

ESCUDERO, José María (1869): Crónica de la provincia de Guadalajara. Madrid.

FELIPE, Helena de (1997): Identidad y onomástica de los beréberes de al-Andalus. Madrid

FERNÁNDEZ-GALIANO RUIZ, Dimas (1977): «Informe sobre la campaña de excavaciones llevada a cabo en Recópolis ( Zorita de los Canes ) en julio de 1976», Wadal-Hayara. 4, pp. 251-253.

FERNÁNDEZ MADRID, María Teresa (1985): «La conquista de Guadalajara vista por los historiadores del siglo XVII: análisis crítico», Wad-al-Hayara. 12, pp. 27-34.

FERNÁNDEZ UGALDE, Antonio (2001): «Sobre la identificación arqueológica de los asentamientos beréberes en la Marca Media de al-Andalus», en Fernando Valdés Fernández y A. Velázquez (eds.), La islamización de la Extremadura Romana, Cuadernos Emeritenses. 17, pp. 139-189

FERRERO ROS, Susana y GARCÍA-SOTO MATEOS, Ernesto (2007): «Excavaciones arqueológicas en el átrio de la Iglesia de Nuestra Señora de los Huertos (Sigüenza, Guadalajara)», en Juan Manuel Millán Martínez y Concepción Rodríguez Ruza (eds.), Arqueología de Castilla-La Mancha. Actas de las I Jornadas (Cuenca 13-17 de diciembre de 2005). Cuenca, pp. 615-640

GÁMEZ, Berta y TORRES, José María (2005): «Nueva interpretación del castillo de Palazuelos (Sigüenza, Guadalajara) tras las intervenciones arqueológicas en el periodo 1998-2002», en Amador Ruibal Rodríguez (ed.), Actas del III Congreso de Castellología Ibérica: 28 de octubre-1 de noviembre de 2005, Guadalajara. Madrid, pp. 991-998

GARCÍA-CONTRERAS RUIZ, Guillermo (2009): «Territorio y explotación de la sal en el valle del Salado (Guadalajara) en época andalusí», Arqueología y Territorio. 6, pp. 211-224

- (2010): «Aportación al estudio de la cerámica andalusí en la Marca Media: el valle del Salado (Sigüenza, Guadalajara)», Martínez peñín, Raquel y Crespo Díez, Manuel (eds.) Metodología de análisis aplicada a los estudios de cerámica tardoantigua y medieval de la Península Ibérica. León, pp. 91-102
- (2012a): «La producción salinera y la economía agropastoril en la cuenca del Alto Henares en época medieval (siglos IX-XIII)» en Paola Galleti (ed.) Paesaggi, comunità, villaggi medievali. Atti del Convegno internazionale di Studio. Bologna, 14-16 gennaio 2010. Spoleto, 2012, t. 1, pp. 171-188

- (2012b): «Hydrogeological conditions in the medieval settlement pattern in the Northeast Valleys of Guadalajara (Spain)» en Bertoncello, Fredérique, y Braemer, Frank (eds.) Variabilités environnementales, mutations sociales. Natures, intensités, échelles et temporalités des changements. Actes des XXXIle Recontres internacionales d'archéologie et d'histoire d'Antibes 20-22 octobre 2011. Antibes, Éditions APDCA, pp. 281-291

- (2012c): «Reflexiones sobre la organización social del espacio del norte de Guadalajara antes de la conquista castellana: Riba de Santiuste y su territorio (siglos IX-XII)» en Arizaga Bolumburu, Belén, Mariño Veiras, Dolores, Díez Herrera, Carmen, Peña Bocos, Esther, Solórzano Telechea, Jesús Ángel, Guijarro Gonzáles, Susana y Añibaro Rodríguez, Jesús (Eds.) Mundos medievales: espacios, sociedades y poder. Homenaje al profesor José Ángel García de Cortázar y Ruiz de Aguirre. Cantabria, Ediciones de la Universidad de Cantabria, t. 1, pp. 545-556

- (2013a): Los valles del Alto Henares en época andalusí. La organización del poblamiento y su relación con las explotaciones salineras (siglos VIII-XII). Tesis doctoral dirigida por Antonio Malpica Cuello. Granada, Universidad de Granada, 2013

- (2013b): «Et cum Salinis. Aproximación documental a las salinas del norte de Guadalajara en los siglos XII-XII|» en Villar Mañas, Sonia (ed.), Sal, agricultura y ganadería: la formación de los paisajes rurales en la Edad Media. Palma de Mallorca, Vessants, pp. 169-204

- (2014): «"Destruqta atque dessolata”. Acerca del lugar de Sigüenza en época altomedieval (ss. V-XII)», Debates de Arqueología Medieval. 4 (2014), pp. 67-110

- (2015): «Châteaux et paysans dans le nord de Guadalajara: réflexions sur l'étude du peuplement rural à la frontière d' al-Andalus», en Sophie Gilotte y Elise Voguet (eds.), Terroirs d'Al-Andalus et du Maghreb médiéval VIIleXVe siècle. Peuplements, ressources et sainteté. colección Bibliothèque de la Méditerranée de la Paris, ed. Bouchène, Saint-Denis, 2015, pp. 51-82

- (2016a): «Where is power in a marginal and border area? Northern Guadalajara in the times of al-Andalus (8th-11th centuries)» en Fábregas, Adela y Sabaté, Flocel (eds.), Power and rural communities in al-Andalus. Ideological and Material Representations. Brepols, The Medieval Countryside, 2015, pp. 53-84.

- (2016b): «Primera aproximación a la tipología cerámica andalusí del noreste de Guadalajara: materiales de la prospección de los valles del Salado y el Alto Henares», en García Porras, Alberto (ed.), Cerámica Medieval e Historia económica y social: problemas de método y casos de estudio. Granada (en prensa).

GARCÍA ÉCIJA, Ángeles (2004): Testigos de la historia de Sigüenza: Historiografía seguntina a través de las fuentes documentales. Sigüenza. 
GARCÍA LÓPEZ, Juan-Catalina (1894): La Alcarria en los dos primeros siglos de su Reconquista. Guadalajara, Reed. en 1973 por la Institución Provincial de Cultura "Marqués de Santillana".

- (1899): Biblioteca de escritores de la provincia de Guadalajara y bibliografía de la misma hasta el siglo XIX. Madrid

- (1906-1911): Catálogo monumental de la provincia de Guadalajara. Guadalajara, editado en 2001 por aache editores, $C D$.

GARCÍA LÓPEZ, Juan-Catalina y PÉREZ VILLAMIL, Manuel (1903-1915): Relaciones Topográficas de España. Relaciones de pueblos que pertenecen hoy a la provincia de Guadalajara. Madrid, Reedición en CD editada por aache ediciones (2002)

GARCÍA LÓPEZ, Aurelio (1992): «Relaciones de los corregidores y justicia mayor de Guadalajara, Molina, Atienza, Uceda y Almonacid de Zorita enviadas a Felipe II en 1571, con motivo del repartimiento de los moriscos de Granada», Wad-al-Hayara. 19, pp. 173-191

GARCÍA MARTÍNEZ, Antonio (2008): Villaseca de Henares. Balcón del río Dulce. Guadalajara

GARCÍA SÁINZ DE BARANDA, Julián y CORDAVIAS, Luis (1929): Guía Arqueológica y de Turismo de la Provincia de Guadalajara. Guadalajara.

GARCÍA SAN JUAN, Alejandro (2011): «La distorsión de alAndalus en la memoria histórica Española», Intus-Legere Historia. $7 / 2$ pp. $61-76$

- (2012): «Al-Andalus en la historiografía del nacionalismo españolista (siglos XIX-XXI). Entre la Reconquista y la España musulmana» en Diego Melo Carrasco y Francisco Vidal Castro (eds.), A 1300 años de la conquista de alAndalus (711-2011): Historia, Cultura y legado del Islam en la Península Ibérica. Chile, pp. 65-104

- (2013): La Conquista Islámica de la Península Ibérica y la tergiversación del pasado: del catastrofismo al negativismo. Barcelona, Marcial Pons.

GARCÍA-SOTO MATEOS, Ernesto (1999): «Semblanza biográfica de Enrique de Aguilera y Gamboa», en Enrique de Aguilera y Gamboa, El Alto Jalón. Descubrimientos arqueológicos. Sigüenza, pp. 11-32

- (2005): «La comarca seguntina en época islámica, siglos VIII-XII», Anales Seguntinos. 21, pp. 7-37

- (2009): «El yacimiento de Castilviejo en Cubillas del Pinar», El Afilador. 5, http://www.elafilador.net/2009/05/ yacimiento_castilviejo_cubillas_pinar

GARCÍA-SOTO MATEOS, Ernesto y FERRERO ROS, Susana (2002): «Excavaciones en el despoblado musulmán de Los Casares (Riba de Saélices: Guadalajara): Campañas de 1998, 1999 y 2000», en Ernesto García-Soto Mateos y Miguel Ángel García Valero (eds.), Actas del primer Simposio de Arqueología de Guadalajara. Homenaje a Encarnación Cabré Herreros. Madrid, t. 2, pp. 513-529

- (2006): «Excavaciones en las salinas de San Juan (Saelices de la sal, Guadalajara)», Boletín de la Asociación de Amigos del Museo de Guadalajara. 1, pp. 81-112
- (2007a): «Un posible barrio artesanal en el poblado hispanomusulmán de los Casares (Riba de Saélices, Guadalajara)», en Juan Manuel Millán Martínez y Concepción Rodríguez Ruza (eds.), Arqueología de Castilla-La Mancha I Jornadas. Cuenca 13-17 de diciembre de 2005. Cuenca, pp. 659-680

- (2008): «La atalaya islámica del "Cerro de la Quebrada" o "El Mirador del Cid" de Sigüenza y algunas consideraciones sobre las fortificaciones islámicas del nordeste de la provincia de Guadalajara», en Ernesto GarcíaSoto Mateos, Miguel Ángel García Valero, y Juan Pablo Martínez Naranjo (eds.), Actas del segundo simposio de Arqueología de Guadalajara. Molina de Aragón, 20-22 de abril de 2006. Madrid, pp. 265-278

GARCÍA-SOTO MATEOS, Ernesto; FERRERO ROS, Susana, y GUILLÉN ÁLVAREZ DE SOTOMAYOR, Adolfo (2004): «LOS Casares: un poblado hispanomusulmán en las serranías del norte de la provincia de Guadalajara», Investigaciones arqueológicas en Castilla-La Mancha, 1996-2002. Toledo, pp. 395-408

GARCÍA-SOTO MATEOS, Ernesto y GARCÍA VALERO, Miguel Ángel (eds.) (2002): Actas del primer Simposio de Arqueología de Guadalajara. Homenaje a Encarnación Cabré Herreros. 2 vols., Madrid

GARCÍA-SOTO MATEOS, Ernesto, GARCÍA VALERO, Miguel Ángel, y MARTíNEZ NARANJO, Juan Pablo (eds.) (2008): Actas del segundo simposio de Arqueología de Guadalajara. Molina de Aragón, 20-22 de abril de 2006. Madrid

GAYA NUÑO, Juan Antonio (1935): «Restos de construcciones musulmanas en Mezquetillas y Fuentearmegil (Soria)», Al-Andalus. III, pp. 151-155

GILOTTE, Sophie (2010): Aux marges d'al-Andalus. Peuplement et habitat en Estrémadure centre-orientale (VIIle-XIIle siècles). Helsinki, 2 vols

GISMERA VELASCO, Tomás (2002): Francisco Layna Serrano. El Señor de los Castillos. Guadalajara.

GÓMEZ-PANTOJA, Joaquín y LÓPEZ TRUJILLO, Miguel Ángel (1996): «Los inicios de la arqueología moderna en Guadalajara: Dos notas sobre yacimientos poco conocidos», Actas del V Encuentro de Historiadores del valle del Henares. Guadalajara, pp. 19-30

GONZÁLEZ, Julio (1975): Repoblación de Castilla La Nueva. 2 vols., Madrid.

GONZÁLEZ CHANTOS Y ULLARI, Diego Eugenio (1806): Santa Librada Virgen y Mártir Patrona de la Santa Iglesia, ciudad y obispado de Sigüenza. Madrid

GRANJA, Francisco de la (1967): «La Marca Superior en la obra de al-Udri», Estudios de la Edad Media en la Corona de Aragón. VIII, pp. 447-545

GUICHARD, Pierre (1976): Al-Andalus. Estructura antropológica de una sociedad islámica en Occidente. Barcelona (reed. Universidad de Granada, 1998)

- (1997): «E. Manzano Moreno "La frontera de al-Andalus en época de los Omeyas" (Book Review)», Arabica. 44 (1), pp. 150-154 
HERRERA CASADO, Antonio (1985): «La Marca Media de al-Andalus en tierras de Guadalajara», Wadal-Hayara. 12, pp. $9-26$

- (1987): «Los cronistas provinciales de Guadalajara (1885-1971)», Wad-al-Hayara. 14, pp. 347-354.

IGLESIAS VECINO, Eusebio (1992): «La romanización de la comarca de Atienza», en Jesús Valiente Malla (ed.), La Celtización del Tajo Superior: estudios de arqueología. Alcalá de Henares, Memorias del Seminario de Historia Antigua III, pp. 70-106.

IZQUIERDO BENITO, Ricardo (1979): «Avance de las excavaciones realizadas en la ciudad Hispanomusulmana de Vascos (Navalmoralejo, Toledo)», XV Congreso Nacional de Arqueología, Lugo, 1977. Zaragoza, pp. 1161-1172

- (1982): «La ciudad hispano-musulmana de Vascos (Navalmoralejo, Toledo). Campaña 1979-1980», Noticiario Arqueológico Hispano. 16, pp. 291-380.

- (2005a): «La arqueología medieval en un grado de arqueología», Complutum. 16, pp. 221-230

- (2005b): «La arqueología medieval en España: antecedentes y estado actual», Arqueología y Territorio Medieval. 1, pp. $119-128$

- (2011): «Los últimos 25 años de arqueología medieval en Castilla-La Mancha (1985-2010)», Boletín de Arqueología Medieval. 15, pp. 233-264

JIMÉNEZ ESTEBAN, Jorge (1989): «Aportación a la arqueología hispano-musulmana: Peñahora (Guadalajara)», Wadal-Hayara. 16, pp. 283-292

- (1992-1993): Castillos de Guadalajara. 2 vols., Madrid

JIMÉNEZ GADEA, Javier (1995): «Los asentamientos beréberes en al-Andalus», en José Ignacio de la Iglesia Duarte (ed.), V Semana de estudios medievales: Nájera, 1 al 15 de agosto de 1994. Nájera, Instituto de Estudios Riojanos, pp. 209-215

JIMÉNEZ SANZ, Carmen y GARCÍA-SOTO MATEOS, Ernesto (2008): «El inventario de la colección Cerralbo elaborado por Juan Cabré Aguiló, un documento excepcional», en Ernesto García-Soto Mateos, Miguel Ángel García Valero, y Juan Pablo Martínez Naranjo (eds.), Actas del Segundo Simposio de Arqueología de Guadalajara. Madrid, pp. 517-539

LALIENA CORBERA, Carlos y UTRILLA UTRILLA, Juan F. (eds.) (1998): De Toledo a Huesca. Sociedades medievales en transición a finales del siglo XI (1080-1100). Zaragoza

LAYNA SERRANO, Francisco (1933a): «El Poblado ibérico, el castro y la caverna prehistórica con relieves en Riba de Saelices (Guadalajara)», Boletín de la Sociedad Española de Excursiones. XLI, p. 183

- (1933b): Castillos de Guadalajara, Madrid (reed. Guadalajara, 1994)

- (1935): La Arquitectura Románica en la Provincia de Guadalajara, Madrid (reed. Guadalajara, 1971)

- (1942): Historia de Guadalajara y sus Mendoza durante los siglos XV X XVI, 4 vols, Madrid (reed. Guadalajara, 1993)
- (1945): Historia de la villa de Atienza. Madrid (reed. Guadalajara, 2004)

- (1955): Historia de la villa de Cifuentes. Madrid (reed. Guadalajara, 1997)

LÓPEZ GÓMEZ, Antonio (1966): «La casa rural y los pueblos en la serranía de Atienza», Estudios Geográficos. XXVII (104), pp. 349-431

- (1967): «Geografía urbana de Atienza», Estudios Geográficos. XXVIII (109), pp. 453-497

- (1969): «El distrito minero de Hiendelaencina (Guadalajara)», Cuadernos de Geografía. 6, pp. 211-250

- (1970): «Salinas de la comarca de Imón (Guadalajara)», Revista de Estudios Geográficos. 122, pp. 371-394

- (1974): «Colectivismo y sistemas agrarios en la Serranía de Atienza (Guadalajara)», Estudios Geográficos. 137, pp. 519-578

- (1984): «Noticias de Campomanes (1779) sobre el noreste de Guadalajara: Atienza, salinas de Imón e introducción de la patata», Estudios Geográficos. 176, pp. 371-374

- (1990): Atienza 1752. Según las Respuestas Generales del Catastro de Ensenada. La Alcabala del Viento, Madrid

- (1993): «Las comarcas de Guadalajara según las "Relaciones Topográficas de Felipe II”», Homenaje académico a D. Emilio García Gómez. Madrid, Real Academia de la Historia, pp. 289-308

- (1997): «La vivienda rural en Guadalajara en el siglo XVI según las "Relaciones Topográficas de Felipe II"», Estudios Geográficos. 58 (229), pp. 643-666

LÓPEZ-MUÑIZ MORAGAS, Gonzalo (2006): «El conjunto fortificado de Palazuelos (Guadalajara): noticias de sus avatares y restauraciones (1931-1978)», en José Javier Rivera Blánco (ed.), Arqueología, arte y restauración: actas del IV Congreso Internaiconal "Restaurar la Memoria", Valladolid, 2004. Valladolid, pp. 439-452

LÓPEZ TRUJILLO, Miguel Ángel (1997): «Un inventario arqueológico y artístico inédito. La Comisión de Monumentos de Guadalajara (1844-1845)», en Gloria Mora Rodríguez y Margarita Díaz Andreu (eds.), La cristalización del pasado: Génesis y desarrollo del marco institucional de la Arqueología en España. Málaga, pp. 231-238

LÓPEZ TRUJILLO, Miguel Ángel y GARCÍA-RISCO VIGERA, Ma del Carmen (1996): «La Comisión de Monumentos de Guadalajara (1835-1939). Breve reseña histórica e inventario de fuentes», La investigación y las fuentes documentales de los archivos. Actas de las I y II Jornadas sobre Investigación en Archivos. Guadalajara, t. I, pp. 443-456

MADOZ, Pascual (1845-1850): Diccionario GeográficoEstadístico-Histórico de España y sus posesiones de Ultramar. Madrid, 1845-1850: Castilla-La Mancha, Valladolid (Reed. 1987)

MADRIGAL BELINCHÓN, Antonio y PERLINES BENITO, María (eds.) (2010): Actas de las II Jornadas de arqueología de Castilla-La Mancha. 2 vols., Toledo 
MAIER ALLENDE, Jorge (1999): Comisión de Antigüedades de la Real Academia de la Historia. Castilla-La Mancha. Madrid, Real Academia de la Historia

MALPICA CUELLO, Antonio y GARCÍA-CONTRERAS RUIZ, Guillermo (2010): «Asentamientos y explotación de la sa en el valle del Salado y la zona de Sigüenza en época altomedieval», En la España Medieval. 33, pp. 295-324

MALPICA CUELLO, Antonio; MORĖRE MOLINERO Nuria; FÁBREGAS GARCÍA, Adela y JIMÉNEZ GUIJARRO, Jesús (2008): «Organización del territorio y explotación de la sal en el área del Río Salado (Sigüenza, Guadalajara, España): Antigüedad y Edad Media. Resultados de la I Campaña 2008», Actas del XI Encuentro de Historiadores del valle del Henares. Guadalajara, pp. 49-62.

- (2011): «Land organisation and salt production in region of the Salado River (Sigüenza, Province of Guadalajara, Spain): Ancient and Medieval Times. Results of the First Campaign 2008», en Marius Alexianu, Olivier Weller, y Roxana- Gabriela Curca (eds.), Archaeology and Anthropology of Salt: A Diachronic Approach. Proceedings of the International Colloquium, 1-5 October 2008 Al. I. Cuza University (Iasi, Romania). Oxford, BAR International Series 2198, pp. 179-185.

MALPICA CUELLO, Antonio; MORÈRE MOLINERO, Nuria; JIMÉNEZ GUIJARRO, Jesús y GARCÍA-CONTRERAS RUIZ, Guillermo (2011): «Paisajes de la sal en la Meseta castellana desde la Prehistoria a la Edad Media: el valle del Salado (Guadalajara)» en Jiménez Puertas, Miguel y García-Contreras Ruiz, Guillermo, Paisajes históricos y Arqueología Medieval. Granada, pp. 233-276

MANZANO MORENO, Eduardo (1991): La frontera de alAndalus en época de los Omeyas. Madrid.

MARÍN, Manuela (1995): «Ulemas en la Marca Media», Estudios onomástico-biográficos de al-Andalus. VII, pp. 203-229.

MARTÍN VISO, Iñaki (2000): Poblamiento y estructuras sociales en el norte de la Península Ibérica (siglos VI-XIII). Salamanca

MARTÍNEZ DÍEZ, Gonzalo (2005): El condado de Castilla (711-1038). La historia frente a la leyenda. 2 vols. Valladolid

MARTÍNEZ LILLO, Sergio y SERRANO-PIEDECASAS FERNÁNDEZ, Luis (1998): «El poblamiento andalusí en Al-Tagr al-Awsat (Marca Media). El mundo omeya», en Antonio Malpica Cuello (ed.), Castillos y territorio en al-Andalus. Granada, pp. 71-115

MARTÍNEZ SASTRE, Vicente y VALIENTE MALLA, Jesús (1990): «Un asentamiento campaniforme en las Tetas de Viana (Viana de Mondéjar, Guadalajara)», Wad-alHayara. 17, pp. 7-42.

MARTÍNEZ SECO, Paz y RUIZ TREVIÑO, Carmen (2008): «Hallazgos más destacados aparecidos en las intervenciones arqueológicas realizadas durante los últimos años en Sigüenza», en Ernesto García-Soto Mateos, Miguel Ángel García Valero, y Juan Pablo Martínez Naranjo (eds.), Actas del segundo simposio de Arqueología de Guadalajara. Molina de Aragón, 20-22 de abril de 2006. Madrid, pp. 383-400.
MARTINEZ TABOADA, Pilar (1985a): «Inicios de la transformación urbanística en la Alcarria: La repoblación», Wad-al-Hayara. 12, pp. 57-64

- (1985b): «Desarrollo urbanístico de las ciudades episcopales: Sigüenza en la Edad Media», En la España Medieval. 7, pp. 957-972

- (1990): Urbanismo medieval y renacentista en la provincia de Guadalajara: Sigüenza, un ejemplo singular. 2 vols., Madrid, Universidad Complutense de Madrid. Tesis Doctoral

- (2011-2012): «La ciudad de Sigüenza a finales de la Edad Media: fuentes para su estudio», Anales Seguntinos. 26, pp. 15-26.

MÉLIDA Y ALINARI, José Ramón (1926): «Ocilis (Medinaceli). Memoria de las excavaciones practicadas en 1924-1925», Memoria de la Junta de Excavaciones y Antigüedades, 82

MILLÁN MARTÍNEZ, Juan Manuel y RODRÍGUEZ RUZA, Concepción (eds.) (2007): Arqueología de Castilla-La Mancha. I Jornadas. cuenca 13-17 de diciembre de 2005. Cuenca

MINGUELLA Y ARNEDO, Toribio (1910): Historia de la diócesis de Siqüenza y sus obispos, I Desde los comienzos de la diócesis hasta finales del siglo XIII. Madrid.

MITRE FERNÁNDEZ, Emilio (2003): «La historiografía sobre la Edad Media», en José Andrés-Gallego (ed.), Historia de la historiografía española. Madrid, Ediciones Encuentro, pp. 71-122

MONSALVO ANTÓN, José María (2003): «Frontera pionera, monarquía en expansión y formación de los concejos de villa y tierra. Relaciones de poder en el realengo concejil entre el Duero y el Tajo (c. 1072-c. 1222)», Arqueología y Territorio Medieval. 10 (2), pp. 45-126

MONTERO, José Antonio (2005): «Por tierras de Sigüenza y Atienza, un parque temático de la Edad Media», Turismo rural. 95 , pp. 58-67

MORĖRE MOLINERO, Nuria (1983): Carta arqueológica de la región seguntina. Madrid, Institución Provincial de Cultura "Marqués de Santillana"

- (1985): «Dos conjuntos de tumbas antropomorfas de la Meseta Sur: provincias de Guadalajara y Madrid», Actas del I Congreso de Arqueología Medieval Española. Huesca, t. V, pp. 275-288

- (1991): «L'exploitation romaine du sel dans la région de Sigüenza», Gerion. 3, pp. 223-235

- (1994): «La sal en la Península Ibérica. Los testimonios literarios antiguos», Hispania Antiqua. XVIII, pp. 235-250

- (2002): «La sal según la "geografía" de Estrabón. Un mapa de la sal y algunas aportaciones», en Liborio Hernández Guerra, Luis Sagredo San Eustaquio, y José María Solana Sáinz (eds.), Actas del I Congreso Internacional de Historia Antigua "La Península Ibérica hace 2000 años" Valladolid, 23-25 de noviembre 2000. Valladolid, pp. 520-527 
- (2008a): «La sal en el desarrollo histórico de Sigüenza», en Nuria Morère Molinero (ed.), Las salinas y la sal de interior en la historia: economía, medio ambiente y sociedad. Madrid, t. I, pp. 3-30

- (2008b): «Une nouvelle approche de Pline sur le sel et I' eau salée», en Olivier Weller, Alexa Dufraisse, y Pierre Pétrequin (eds.), Sel, eau et forêt d'hier à aujourd'hui. Paris, pp. 365-380

- (2011): «Historical development of the "salinae" in Ancient Rome: from technical aspects to political and socio-economic interpretations», en Marius Alexianu, Olivier Weller, y Roxana-Gabriela Curca (eds.), Archeology and Anthropology of Salt: a Diachronic Approach. Oxford, BAR International Series 2198, pp. 155-163

MORÈRE MOLINERO, Nuria; JIMÉNEZ GUIJARRO, Jesús, y GARCÍA-CONTRERAS RUIZ, Guillermo: «La explotación de sal en época prerromana y romana en la Meseta oriental: el río Salado de Sigüenza a la luz de algunos materiales inéditos», en María Luisa Cerdeño Serrano, Emilio Gamo Pazos, y Teresa Sagardoy (eds.), La romanización de Guadalajara: arqueología e historia. Guadalajara, La Ergástula, 2013, pp. 91-110.

MUÑOZ JIMÉNEZ, José Miguel (2008): «La primera intervención restauradora en el castillo de Atienza (Guadalajara): Valoración histórica», en Ernesto GarcíaSoto Mateos, Miguel Ángel García Valero, y Juan Pablo Martínez Naranjo (eds.), Actas del segundo simposio de Arqueología de Guadalajara. Molina de Aragón, 20-22 de abril de 2006. Madrid, pp. 431-441.

OLEA ÁlVAREZ, Pedro A. (2009): Sigüenza entre las dos Castillas y Aragón. Historia social, politica y religiosa de las tierras de su obispado hasta 1.300. Bilbao.

OLMO ENCISO, Lauro (1983): «Restos defensivos de la ciudad visigoda de Recópolis», Homenaje al prof. Martín Almagro Basch. Madrid, vol 4, pp. 67-74

- (1988): «Arquitectura religiosa y organización litúrgica en época visigoda: la Basílica de Recópolis», Archivo Español de Arqueología, 61, 157-158, pp. 157-178

- (1988b): «La ciudad visigoda de Recópolis», I Congreso de Historia de Castilla-La Mancha. Ciudad-Real, vol. 4, pp. 305-312

- (2000): «Ciudad y procesos de transformación social entre los siglos VI y IX: de Recópolis a Racupel», en Luis Caballero Zoreda y Pedro Mateos Soto (eds.), Visigodos y Omeyas. Un debate entre la Antigüedad Tardía y la Alta Edad Media. Madrid, Anejos del Archivo Español de Arqueología, t. XXIII, pp. 385-399

- (2002): «Arqueología Medieval en Guadalajara. Un estado de la cuestión», en Ernesto García-Soto Mateos y Miguel Ángel García Valero (eds.), Actas del primer simposio de Arqueología de Guadalajara. Homenaje a Encarnación Cabré Herreros. Guadalajara, t. II, pp. 467-500

- (2008): «Recópolis: una ciudad en una época de transformaciones», en Lauro Olmo Enciso (ed.), Recópolis y la ciudad en la época visigoda. Zona Arqueológica. t. 9, pp. 41-62
- (2011): «De Celtiberia a Šantabariyya: La gestación del espacio y el proceso de formación de la sociedad andalusí (ss. VIII-IX)», Zona Arqueológica. 15 (2), pp. 39-64

ORTEGA ORTEGA, Julián (2000):«Monumentos, estrategias de identidad y cambio social: el puente de Calamocha (Teruel) como lugar de la memoria», Xiloca. 26, pp. $13-26$

ORTIZ GARCÍA, Antonio (1999): «Las “Relaciones Topográficas de la provincia de Guadalajara" y sus autores (ante la reedición de esta obra)», Wad-al-Hayara. 26, pp. 75-97

ORTIZ GARCÍA, Antonio y RUBIO FUENTES, Manuel (2000): Historia de la villa de Mandayona. Guadalajara

ORTIZ DEL CUETO, José Ramón, PANTOJA HERNÁNDEZ, Pedro F., y SÁNCHEZ ORTIZ, Antonio J. (2010): «La Carta Arqueológica de Castilla-La Mancha en el siglo XXI: Instrumento de protección preventiva y planificación territorial en la gestión del Patrimonio Cultural», en Antonio Madrigal Belinchón y María Perlines Benito (eds.), Actas de las II Jornadas de Arqueología de Castilla-La Mancha. Toledo 2007. Toledo, t. 2, pp. 1078-1120

PAREJA SERRADA, Antonio (1921): Diplomática Arriacense. Colección de algunos documentos, publicados unos, inéditos otros, que pueden servir para planear o ilustrar una "Historia de Guadalajara y su provincia". Guadalajara.

PAVÓN MALDONADO, Basilio (1982): Alcalá de Henares medieval. Arte islámico y mudéjar. Madrid, CSIC

- (1984): Guadalajara medieval. Arte y arqueología árabe y mudéjar. Madrid, C.S.I.C

PÉREZ DE URBEL, Justo (1969): El Condado de Castilla. Los trescientos años en que se hizo Castilla. 2 vols., Madrid

PÉREZ-VILLAMIL, Manuel (1899): Estudios de Historia y Arte. La Catedral de Sigüenza. Madrid.

PICATOSTE, Valentín (1890): Descripción e historia política, eclesiástica y monumental de España. Provincia de Guadalajara. Guadalajara

PORTELA, Ermelindo (1985): «Del Duero al Tajo», en José Ángel García de Cortazar y Ruiz de Aguirre (ed.), Organización social del espacio en la España medieval. La corona de Castilla en los siglos VIII a XV. Barcelona, pp. 85-122

QUIROS CASTILLO, Juan Antonio (2009): «Medieval Archaeology in Spain», en Roberta Gilchrist y Andrew Reynolds (eds.), 50 years of medieval archaeology in Britain and beyond. London, Society for Medieval Archaeology Monograph, t. 30, pp. 173-189.

QUIRÓS CASTILLO, Juan Antonio y BENGOETXEA REMENTERIA, Belén (2006): Arqueología (III) Arqueología Postclásica. Madrid

RADA DELGADO, Juan de Dios de la (1894): Bibliografía histórico-alcarreña. Madrid

RANZ YUBERO, José Antonio y LÓPEZ DE LOS MOZOS JIMÉNEZ, José Ramón (1997): «Topónimos defensivos que aparecen en las relaciones topográficas de Felipe |l», Wad-al-Hayara, 24, pp. 317-334 
- (1999): Toponimia y arqueología: yacimientos arqueológicos de Guadalajara y su denominación. Guadalajara

- (2001): «Población, reconquista y repoblación de los pueblos de la cuenca del río Henares a su paso por la provincia de Guadalajara, a través de la toponimia», VII Encuentro de historiadores del valle del Henares. Guadalajara 5-8 abril de 2001. Guadalajara, Institución Marqués de Santillana de Guadalajara, pp. 97-113

- (2002): «La expedición de Ordoño II según el cronicón de Sampiro: estado de la cuestión. Toponimia y nueva identificación de lugares», Actas del VIII encuentro de Historiadores del Valle del Henares (Alcalá de Henares, 2002). pp. 379-393

RETUERCE VELASCO, Manuel (1984a): «La cerámica islámica de Calatalifa. Apuntes sobre los grupos cerámicos de la Marca Media», Boletín del Museo Arqueológico Nacional. II, pp. 117-136

- (1984b): «Cerámicas islámicas procedentes de Torete (Guadalajara): nuevos datos sobre los grupos cerámicos de la Marca Media», Boletín de la Asociación Española de Orientalistas. 20, pp. 339-357

- (1994): "Carta arqueológica de la Meseta andalus según el referente cerámico» Boletín de Arqueología Medieval. 8, pp. 7-110

- (1995): «Arqueología y poblamiento en la Meseta Andalusí: El referente cerámico», en José Ignacio de la Iglesia Duarte (ed.), V Semana de Estudios Medievales: Nájera, 1 al 15 de agosto de 1994. La Rioja, pp. 87-124

- (1998): La cerámica andalusí en la Meseta. 2 vols. Madrid.

RETUERCE VELASCO, Manuel y ZOZAYA, Juan (1986): «Variantes geográficas de la cerámica omeya andalusí: los temas decorativos», La ceramica medievale nel Mediterraneo Occidentale (Siena-Faenza, 1984). Florencia, pp. 69-128.

ROSSELLÓ, Vincenç M. (2004): «Antonio López Gómez. Semblanza personal y científica», en Historia, clima y paisaje. Estudios geográficos en memoria del profesor Antonio López Gómez. Valencia, pp. 11-26.

ROSSELLÓ BORDOY, Guillermo (1978): Ensayo de sistematización de la cerámica árabe en Mallorca. Mallorca.

SÁENZ RIDRUEJO, Clemente (1984): «Identificaciones toponómicas en la antigua tierra de Atienza y sus confines», Homenaje a Julián Marías. Madrid, Espasa-Calpe, pp. 657-668

SÁEZ LARA, Fernando, MALALANA UREÑA, Antonio, y MARTÍNEZ LILLO, Sergio (1999): «Poblamiento y red viaria en la marca media. Un comienzo de aproximación (ss. VIII-X)», en Rodrigo de Balbín Behrmann y Primitiva Bueno Ramírez (eds.), Il Congreso de Arqueología Peninsular. Zamora, del 24 al 27 de septiembre de 1996. Alcalá de Henares, t. IV - Arqueología Romana y Medieval, pp. 537-554.

SALGADO CARMONA, José Ángel, DAZA PARDO, Enrique, y VEGA RIVAS, Elena (2008): «Estudio diacrónico del poblamiento histórico del valle del Torote. El cerro del
Castillo de Alcolea en Torrejón del Rey (Guadalajara)», en Ernesto García-Soto Mateos, Miguel Ángel García Valero, y Juan Pablo Martínez Naranjo (eds.), Actas del Segundo Simposio de Arqueología de Guadalajara: Molina de Aragón, 20-22 de abril de 2006. Guadalajara, pp. 209-221.

SÁNCHEZ-ALBORNOZ, Claudio (1957): España, un enigma histórico. Buenos Aires, 2 vols.

SÁNCHEZ DONCEL, Gregorio (1967): «Biblioteca Alcarreña», Investigación. 1, pp. 15-36

- (1969): «Biblioteca Alcarreña», Investigación. 3, pp. 49-68

- (1970): «Biblioteca Alcarreña», Investigación. 4, pp. 21-46

- (1977): Wad-al-Hayara. 4, pp. 275-289

- (1979): Wad-al-Hayara. 6, pp. 275-283

SÁNCHEZ PORTOCARRERO, Diego (1646): Nuevo catálogo de los Obispos de la Santa Iglesia de Sigüenza. Madrid.

SANZ GAMO, Rubí (2010): «Historia de la investigación arqueológica en Castilla-La Mancha: de los pioneros a la problemática actual», en Antonio Madrigal Belinchón y María Perlines Benito (eds.), Actas de las II Jornadas de Arqueología de Castilla-La Mancha. Toledo 2007. Toledo, t. 1, pp. 18-47

SÉNAC, Philippe (1993): «Nota crítica sobre la frontera: Manzano Moreno, Eduardo "La frontera de al-Andalus en época de los omeyas"», Anaquel de estudios árabes. 4, pp. $184-188$

SERRANO COPETE, Javier (2008): Una historia de Anguita. El pueblo y su entorno. Guadalajara.

SERRANO MORALES, Riansares y CABALLERO GARCÍA, Antonio (1994): «Los fondos de la Comisión Provincial de Monumentos y del Patronato Provincial para el fomento de Bibliotecas, Archivos y Museos Arqueológicos, conservados en el Archivo Histórico Provincial de Guadalajara», Wad-al-Hayara. 21, pp. 343-365

SERRANO-PIEDECASAS FERNÁNDEZ, Luis (2007): «Sistemas islámicos de dominio en los Extrema Durii», en Gregorio del Ser Quijano y Iñaki Martín Viso (eds.), Espacios de poder y formas sociales en la Edad Media. Estudios dedicados a Ángel Barrios. Salamanca, Ediciones Universidad de Salamanca, pp. 277-300

SEVILLA MUÑOZ, Julia (1985): «Una consecuencia de la reconquista de Guadalajara: La repoblación de Sigüenza por un obispo aquitano», Wad-al-Hayara. 12, pp. 43-55

TORRES BALBÁS, Leopoldo (1971): Ciudades Hispanomusulmanas. 2 vols., Madrid

TORRES, José María y GÁMEZ, Berta (2012): «Estudio del torreón de acceso del Castillo de Palazuelos (Guadalajara)», IV Congreso de Castellología, Madrid, 7, 8 y 9 de marzo de 2012. Madrid, pp. 657-667

UBIERNA y EUSA, José Antonio (1917): Estudio jurídico de los Fueros municipales de la provincia de Guadalajara. Guadalajara. 
VALIENTE MALLA, Jesús (1997): Guía de la Arqueología en Guadalajara. Guadalajara, aache ediciones

VALIENTE MALLA, Jesús y CUADRADO PRIETO, Miguel Ángel (1988): «Las torres de Atienza», Actas del primer Encuentro de Historiadores del valle del Henares. Guadalajara, pp. 631-641

VALIENTE MALLA, Jesús y GARCÍA-GELABERT PÉREZ, María Pilar (1983): «La cueva Harzal de Olmedillas. Resultados de una prospección (Sigüenza, Guadalajara)», Wad-al-Hayara. 10, pp. 7-24

VALLEJO GIRVÉS, Margarita (1999): Los Viajes de Córnide por la Alcarria. Viajes histórico-arqueológicos (1793-1795). Guadalajara.

VALOR PIECHOTA, Magdalena y GUTIÉRREZ GONZÁLEZ, José Avelino (2014): The Archaeology of Medieval Spain 1100-1500. Equinox

VEGA RIVAS, Elena, et alii. (2008): «Nuevas aportaciones a la investigación de las necrópolis medievales de Sigüenza (Guadalajara). Hallazgos realizados en la Casa del Pintor, calle San Roque, 17», en Ernesto GarcíaSoto Mateos, Miguel Ángel García Valero, y Juan Pablo Martínez Naranjo (eds.), Actas del segundo simposio de Arqueología de Guadalajara. Molina de Aragón, 20-22 de abril de 2006. Madrid, pp. 299-312

VELA COSSIO, Fernando y RIVERA GÁMEZ, David (2002): «Protección del patrimonio vernáculo y carta arqueológica. La redacción de la carta arqueológica de Palazuelos, Sigüenza (Guadalajara)», en Ernesto García-Soto Mateos y Miguel Ángel García Valero (eds.), Actas del primer Simposio de Arqueología de Guadalajara. Homenaje a Encarnación Cabré Herreros. Madrid, t. 2, pp. 757-767

VELA COSSIO, Fernando y VILLAFRUELA ARRANZ, Esther (2002): «Intervención arqueológica en el Castillo de Palazuelos. Excavaciones arqueológicas y restauración del patrimonio edificado», en Ernesto García-Soto Mateos y Miguel Ángel García Valero (eds.), Actas del primer Simposio de Arqueología de Guadalajara. Homenaje a Encarnación Cabré Herreros. Guadalajara, t. 2, pp. 801-811

VELA COSSIO, Fernando, et alii (2008): «Noticias de las excavaciones arqueológicas en el claustro de la Catedral de Sigüenza (Guadalajara)», en Ernesto GarcíaSoto Mateos, Miguel Ángel García Valero, y Juan Pablo Martínez Naranjo (eds.), Actas del segundo simposio de Arqueología de Guadalajara. Molina de Aragón, 20-22 de abril de 2006. Madrid, pp. 325-340
VILLAR GARCÍA, Luis Miguel (1986): La Extremadura castellana: guerreros, clérigos y campesinos (711-1252). Valladolid

W.AA. (2004): Investigaciones arqueológicas en Castilla-La Mancha, 1996-2002. Toledo

ZEISS, H. (1934): Die Grabfunde aus dem Spanishen Westgotenreich. Berlín-Leipzig

ZOZAYA, Juan (1970): «Problemática de la arqueología medieval posterior al siglo VIII en España», XI Congreso Nacional de Arqueología, Mérida, 1968. Zaragoza, pp. 846-849

- (1975): "Cerámicas islámicas del Museo de Soria», Boletín de la Asociación Española de Orientalistas. XI. pp. $135-148$

- (1988): «Evolución de un yacimiento: el castillo de Gormaz (Soria)», en André Bazzana (ed.), Castrum 3. Guerre, fortification et habitat dans le monde mediterranéen au Moyen Age. Madrid, pp. 173-178

- (1991): «Recientes estudios sobre la arqueología andalusí: La Frontera Media», Aragón en la Edad Media. IX, pp. 371-372

- (2007): « ¿Poblados?, ¿ciudades?, ¿campamentos? ¿recintos castrales? En la Marca Media: hacia una tipología», en W.AA. Al-Ándalus. País de ciudades. Actas del Congreso celebrado en Oropesa (Toledo) del 12 al 14 de marzo de 2005. Toledo, pp. 23-63

- (2010): «La línea de fortificaciones andalusíes del Duero oriental», Actas del Coloquio Internacional "Patrimonio Cultural y Territorio en el Valle del Duero". Zamora, 28, 29 y 30 de 2007. Valladolid, pp. 235-255

- (2012): «Bocetos para la historiografía de la arqueología andalusí», en Luis A. García Moreno (ed.), 711 Arqueología e historia entre dos mundos. Catálogo de la exposición celebrada en el Museo arqueológico regional, Alcalá de Henares, Madrid, 16 de diciembre de 2011 al 1 de abril de 2012. Madrid, pp. 96-131

ZOZAYA, Juan y FERNÁNDEZ URIEL, Pilar (1983): «Excavaciones en la fortaleza de Qal' at 'Abd al-Salam (Alcalá de Henares, Madrid)», Noticiario Arqueológico Hispano. 17, pp. 411-529 